\title{
Belonging:
}

\section{Citizenship and Migration in the European Union and in Germany}

\author{
By \\ Helen Elizabeth Hartnell*
}

I.

INTRODUCTION

At the dawn of the twenty-first century, the European Union and Germany are magnets for both voluntary and involuntary migrants from around the world. Indeed, one key feature of the contemporary condition known as globalization is a profound increase in mobility and other "more permanent forms of human migration." Thus ever more people face the challenge of withstanding the pulls

* Professor of Law, Golden Gate University School of Law; Ph.D. Candidate in Jurisprudence and Social Policy, University of California, Berkeley; and Visiting Scholar, University of Cologne Legal Centre for European and International Cooperation (R.I.Z.). Thanks are owed to Golden Gate University for generous research support, to R.I.Z. for providing a stimulating and supportive work environment, and to Hannah Luise Buxbaum for comments on an earlier version of this article. The author is a naturalized American citizen who was bom in Germany to American parents. She is not now, nor has she ever been, a national or citizen of Germany, though she feels at home there.

1. Sheila L. Croucher, Globalization and Belonging: The Politics of IDENTity IN a CHANGING WORLD 16 (2004). Croucher documents rising rates of travel and air traffic, along with steadily -if not dramatically-growing numbers of foreign born residents in Australia (24\% in 1999), Canada (17.4\% in 1996), and the United States (11\% in 2000). Social anthropologists, however, offer a different perspective:

Movement within one or two generations rather than fixed settlement has generally

characterised human populations.... What is really new is the awareness among many communities that there are innumerable other such populations linked globally by rapid transport, electronic communication systems and common access to the same consumer goods and styles, and that these often supplement rather than replace older ties forged through ... trade and intermarriage.

David Parkin, Foreword to LOCALITY AND BeLonging, at ix (Nadia Lovell ed., 1998) [hereinafter LOVEll]; see also Nikos Papastergiadis, The TuRbulence of Migration: Globalization, DETERRITORIALIZATION AND HYBRIDITY 76-99 (2000) (exploring the linkages between modernity, globalization, and migration). 
between here and there, of balancing potentially conflicting needs to integrate ${ }^{2}$ (or even assimilate ${ }^{3}$ ) and to maintain transnational ties. ${ }^{4}$ Migrants are differently affected by these and other forces, since their motives and individual circumstances vary widely, yet all share the fact of dislocation. Identities can hardly help but be reshaped in this vortex. ${ }^{5}$ The challenge to identity is starkest where the receiving country demands a high level of integration or

2. The term 'integration' is an alternative to 'assimilation'. The latter term has become suspect in an era characterized by increasingly multicultural societies in many parts of the world. In Germany, for example, "[c]ultural 'assimilation' as a prerequisite for citizenship acquisition was explicitly rejected and replaced by a weaker 'integration' requirement." Christian Joppke, Exclusion in the Liberal State: The Case of Immigration and Citizenship Policy, 8 EUR. J. SOC. THEORY 43, 52 (2005). See generally AdRIAN FAVEll, PHILOSOPHIES OF INTEgration: IMMIGRATION AND THE IDEA OF CITIZENSHIP IN FRANCE AND BRITAIN (2d ed., 2001). For a succinct discussion of the Leitkultur ("leading culture") controversy that erupted in Germany in 2000 , see Ernst B. Haas, Sally Roever \& Anna Schmidt, Germany and the Norms of European Governance, 20 GERMAN POL. \& SOC'Y 148 (2002); see also Richard Bernstein, "A Continent Watching Anxiously Over the Melting Pot," N.Y. TIMES, Dec. 15, 2004 (discussing German "discomfort with multiculturalism" and the belief expressed by " $[\mathrm{m}]$ any politicians and commentators ... that immigrants should accept ... the dominant culture, as their own, or they should leave").

3. Immigrant assimilation as a political project emerged during the "first wave of industrialage migration in the late nineteenth century," and thus has affinities with "imperialist state rivalry, war, and aggressive nation-building." Christian Joppke \& Ewa Morawska, Integrating Immigrants in Liberal Nation-States: Policies and Practices, in TOWARD ASSIMILATION AND CITIZENSHIP: IMMIGRANTS IN LibERAL NATION-STATES 1, 4 (Christian Joppke \& Ewa Morawska eds., 2003) [hereinafter TOWARD ASSIMILATION]. "The essence of old-style assimilation was cultural assimilation, a sort of alchemy through which an immigrant was transformed into a standardized unit of the state-bearing nation." $I d$. at 5 . The contemporary understanding of assimilation imposes "no mandate for immigrants to adopt the substantive culture of the receiving society." Id. It instead refers in social scientific terms to:

a multipath process involving the incorporation of immigrants and their offspring into the economic, political and social institutions, and culture of different segments of the host society: mainstream middle- and rising lower class (so-called upward assimilation), struggling lower- and underclass (downward assimilation), or immigrant/ethnic enclave (also called adhesive... assimilation, which can also follow the intragroup middle- or lower-class pattern).

Ewa Morawska, Immigrant Transnationalism and Assimilation: A Variety of Combinations and the Analytic Strategy it Suggests, in TOWARD ASSIMILATION, supra at 133, 134. Morawska's updated definition virtually erodes the distinction between assimilation and integration, and renders the term assimilation usable in contemporary discourse by excising its "old-style" connotations. Joppke \& Morawska, supra at 1 , argue that there is "a trend in immigration studies ... [to] turn away from multicultural and postnational perspectives, toward a renewed emphasis on assimilation and citizenship."

4. See, e.g., Wolfgang Bergem, Culture, Identity, and Distinction: Ethnic Minorities between Scylla and Charybdis, in GERMAN MINORITIES IN EUROPE: ETHNIC IDENTITY AND CULTURAL BELONGING 1, 1 (Stefan Wolff ed., 2000) [hereinafter WOLFF] ("Ethnic minorities are constantly challenged by two equally threatening perspectives-maintaining their ethnicity and insisting on their cultural distinctiveness bears the danger of marginalisation in their host-state, while attempts aimed at integration imply the no less troublesome possibility of being absorbed into the majority culture and the consequential loss of their particular identity.").

5. "Transnational migration significantly affects individual and collective identities, and it creates new identities." Martin O. Heisler, Now and Then, Here and There: Migration and the Transformation of Identities, Borders, and Orders, in IDENTITIES, BORDERS, ORDERS: RETHINKING INTERNATIONAL RELATIONS THEORY 225, 225 (Mathias Albert et al. eds., 2001) [hereinafter ALBERT ET AL., IBO]. 
assimilation. $^{6}$

Like migrants themselves, countries also vary widely in their treatment of nationality, citizenship, and migration, ${ }^{7}$ as well as in the degree to which they tolerate or promote multiculturalism, on the one hand, or press immigrants to integrate into the host country, on the other. ${ }^{8}$ Recent comparative historical analyses of citizenship in the United States and some European countries, for example, show that countries reflect varying sui generis combinations of "common components of citizenship" that result from "nineteenth- and twentieth-century state-building," as well as from social and political factors that may "pre-date the era of mass politics and even the nation-state." 10 In the context of European integration, however, there is a strong trend towards coordination and in some cases even harmonization in these two fields, and thus towards at least partial convergence. ${ }^{11}$

One such component of citizenship, or avenue for conceptualizing membership in a political community, is the notion of belonging. The American

6. The terms 'assimilation' and 'integration' have an historical relationship:

The old nationalizing and assimilationist idiom ... was carried along until the 1960s; but it remained largely rhetorical, and was mostly not accompanied by related policies. Only when the problem of 'integrating' postcolonial, labor, and new settler migrants, and especially their offspring, seriously emerged in the 1970s and 1980s, was the postwar liberalism and human-rights discourse applied to the immigration domain, and the notion of integration was born.

Joppke \& Morawska, supra note 3, at 4-5. My usage of these two terms arranges them along a continuum from multi- to monoculturalism, with the latter represented by the original nationalist notion of assimilation. Between these two poles lies a range of notions and practices. Despite Joppke and Morawska's effort to resuscitate the term 'assimilation' for use in academic discourse, 1 use the term 'integration' in this article, since it is the term actually used in both Germany and in the European Union, even while recognizing that this term is problematic, insofar as it "rests on the premise of an already integrated, bounded society." Joppke \& Morawska, supra at 3. This premise has been discredited by postclassical sociology, which takes a more "systemic, decentered view of society." Id.

7. The term 'migration' is used here to refer to the sum total of emigration and immigration, without regard to the reasons people leave home in the first place. This topic is addressed infra in Parts II.B and III.B.

8. Joppke \& Morawska, supra note 3, at 1, argue that the "scope of official multiculturalism policies and programs has either been exaggerated in public and academic perception, or, where such policies have actually been in place, there has recently been a covert or overt move away from them."

9. Richard Bellamy, Introduction: The Making of Modern Citizenship, in LINEAGES of EUROPEAN CITIZENSHIP: RightS, BELONGING AND PARTICIPATION IN ElEVEN NATION STATES 1, 4 (Richard Bellamy et al. eds., 2004) [hereinafter Bellamy, The Making of Modern Citizenship and BELLAMY ET AL. respectively] (explaining variation in the citizenship regimes of the European Union, France, Germany, Great Britain, Italy, Portugal, the Netherlands, Scandinavia, Spain, and the United States).

10. Id. at 14. Notably, these factors include "the ways state-church relations were resolved in the sixteenth and seventeenth centuries, whether industrialization came early or late, and the stamp placed on the political system by the earlier struggles occasioned by the growth of monarchical power." Id.

11. European Union developments relating to citizenship and migration are discussed infra in Parts II.A and II.B, respectively. 
myth promising that all can belong ${ }^{12}$ is traditionally viewed as the antithesis of ethno-cultural notions of belonging of the sort that have historically prevailed in Germany. ${ }^{13}$ This contrast, while overdrawn, marks the range of perspectives between the 'primordialist' and 'constructivist' poles of the membership spectrum, ${ }^{14}$ and takes a first step towards grasping the multifaceted nature of belonging.

Belonging is an imperfect analytical concept that tears a jagged path across pertinent legal categories and available political opportunities. This concept has strong appeal to writers in many fields, ${ }^{15}$ since it supplements the usual analytic categories and thus refracts a wider spectrum of contemporary conditions. ${ }^{16}$

12. "America itself was a myth long before it was a place, a people. It was imagined as a New World, a new beginning where orphans and refugees could build a new way of belonging to each other and to the world." MADONNA KOLBENSCHLAG, LOST IN THE LAND OF OZ: THE SEARCH FOR IDENTITY AND COMMUNITY IN AMERICAN LIFE xi (1990). "States, such as the United States, may deliberately foster myths of a shared 'melting-pot' nationhood." Thomas $\mathrm{M}$. Franck, Clan and Superclan: Loyalty, Identity and Community in Law and Practice, 90 AM. J. INT'L L. 359, 362 (1996). For Franck's definitions of 'nation' and 'state' see infra notes 23 and 28, respectively. The nineteenth-century model of assimilation in countries such as Australia, Canada, and the United States expected migrants to transfer their political identity from "home to host state," usually in connection with "the act of renouncing home country citizenship and taking an oath of allegiance during naturalization." Rey Koslowski, Demographic Boundary Maintenance in World Politics: Of International Norms on Dual Nationality, in ALBERT ET AL., IBO, supra note 5, at 203, 214-15.

13. The romantic notion of the German people as a Volk was popularized in the eighteenth century by Johann Gottfried Herder. See generally ROGERS BRUBAKER, CITIZENSHIP AND NATIONHOOD IN FRANCE AND GERMANY (1992). Regardless of the salience this notion once enjoyed (or may continue to enjoy), it is necessary to differentiate between the myth, on the one hand, and the reality of German laws and practices connected with migration and citizenship, on the other hand. See, e.g., DIETER GOSEWINKEL, EINBÜRGERN UND AUSSCHLIESSEN: DIE NATIONALISIERUNG DER STAATSANGEHÖRIGKEIT VOM DEUTSCHEN BUND BIS ZUR BUNDESREPUBLIK DEUTSCHLAND [INCLUSION AND EXClusion: THE NATIONALIZATION OF CITIZENSHIP FROM THE GERMAN CONFEDERATION TO THE FEDERAL REPUBLIC OF GERMANY] (2001); Joppke, supra note 2; Ulrich K. Preuß, Citizenship and the German Nation, in BELLAMY ET AL., supra note 9, at 22-45.

14. See generally Alain Dieckhoff, Introduction: New Perspectives on Nationalism, in THE POLITICS OF BELONGING: NATIONALISM, LiBERALISM, AND PLURALISM 1, 1-2 (Alain Dieckhoff ed., 2004) [hereinafter Dieckhoff] (noting that the literature on nationalism is divided between these two extreme positions). However, Dieckhoff urges caution "when using such exaggeratedly dichotomous distinctions," since both are problematic. Id. at 5. Franck, supra note 12 at 362 , draws a sharp contrast between the constructivist term 'state' and the primordialist terms 'nation' and 'tribe'.

15. See, e.g., Bellamy ET Al., supra note 9; STEPHEN CASTles \& Alastair Davidson, Citizenship AND Migration: Globalization and tHe Politics of Belonging (2000); CROUCHER, supra note 1; Dieckhoff, supra note 14; MARKUS FUNCK ET AL., SACRIFICE AND NATIONAL BELONGING IN Twentieth-CENTURY GeRMANY (Greg Eghigian \& Matthew Paul Berg eds., 2002); THE POLITICS OF BELONGING: MIGRANTS AND MINORITIES IN CONTEMPORARY EUROPE (Andres Geddes \& Adrian Favell eds., 1999); ISABEL HUGGAN, BELONGING: HOME AWAY FROM HOME (2003); MiChaEl IGNATIEFF, BloOD AND BELONGNG (1993); LOVEll, supra note 1; Vivienne Orchard, Culture as Opposed to What? Cultural Belonging in the Context of National and European Identity, 5 EUR. J. SOC. THEORY 419 (2002); E. PROBYN, OUTSIDE BELONGING (1996); Mike SAVAGE, GaYNor Bagnall \& BRian LONGHURST, Globalization and Belonging (2005); VICTOR JELENIEWSKI SEIDLER, SHADOWS OF THE SHOAH: JEWISH IDENTITY AND BELONGING (2000); Elaine R. Thomas, Who Belongs? Competing Conceptions of Political Membership, 5 EUR. J. SOC. THEORY 323 (2002); SAllie WeSTWOOd \& ANNIE PHIZACKLEA, TRANS-NATIONALISM AND THE POLITICS OF BELONGING (2000); WOLFF, supra note 4.

16. Indeed, "belonging exists on as many dimensions as people are prepared to delineate." 
Belonging may be defined through a territorial reference point, ${ }^{17}$ but is not necessarily so. ${ }^{18}$ While some authors emphasize belonging's affective character, ${ }^{19}$ others experience it as physical sensation ${ }^{20}$ or even as essential quality. ${ }^{21}$ Most social scientists, however, view belonging through the optic of

Parkin, supra note 1, at xii; see also Vikki Bell, Performativity and Belonging: An Introduction, 16 THEORY, CULTURE \& SOC'Y 1, 3 (1999) ("Belonging is an achievement at several levels of abstraction."). As Hedetoft and Hjort explain:

[B]elonging constitutes a political and cultural field of global contestation ... summoning a range of pertinent issues concerning relations between individuals, groups, and communities. It raises questions about cultural, sociological, and political transformative processes and their impact on imagined and real boundaries, notions of citizenship and cultural hybridization, migration and other forms of mobility, displacements and so-called ethnic cleansing, and of course also on the extent and nature of perceived normalcies of national belonging.

Ulf Hedetoft \& Mette Hjort, Introduction to THE Postnational Self: BELONGING AND IDENTITY vii, x (Ulf Hedetoft \& Mette Hjort eds., 2002) [hereinafter Hedetoft \& Hjort and HEDETOFT \& HJORT respectively].

17. Nadia Lovell, Introduction to LOVELL, supra note 1, at 1 . In territorial terms, belonging can invoke either the importance of the local in a global era, or geography-based notions of inclusion and exclusion. As to the former, see SAVAGE, BAGNALL \& LONGHURST, supra note 15 , at 7 (arguing for the "ongoing significance of territoriality for social relationships"). The debate over Turkey's push to join the European Union, which is sometimes characterized as being about where to draw the line between Europe and non-Europe, provides an example of the latter approach. See also Preuß, supra note 13 (discussing the special significance of territory in the development of the German notion of nationality).

18. Indeed, belonging appears to be less linked to territory than it has been in the past. Parkin, supra note 1, at ix, notes that "anthropologists can no longer assume that the people they study see themselves as attached to a particular, bounded locality. Diaspora, transnational community and dispersed networks are typically some of the terms used to convey the image of movements of people who retain common socio-cultural consciousness in the face of constant displacement." See also PAPASTERGIADIS, supra note 1, at 39 (discussing "new forms of bilocality"); id. at 100-21 (discussing the deterritorialization of culture); JOHN URRY, SOCIOLOGY BEYOND SOCIETIES 132-33 (2000) (urging replacement of territory-based sociology by a "sociology of flows" since contemporary belonging "almost always involve[s] diverse forms of mobility" and a "dialectic of roots and routes").

19. Belonging, despite its "pragmatic connotations and potential for tying people to place and social relationships, also evokes emotions, sentiments of longing to be in a particular location, be it real or fictive." LovelL, supra note 1, at 1; see also CASTLES \& DAVIDSON, supra note 15, at 130 (" $[\mathrm{H}]$ ome is where one feels a sense of belonging and security, and where one can decide on acceptable values and forms of behaviour."); Hedetoft \& Hjort, supra note 16, at vii (referring to the "thick" view of belonging as "feelings of "homeness" and as a "significant determinant of identity, that elusive but still real psycho-sociological state of being in sync with oneself under given external conditions"); SAVAGE, BAGNALL \& LONGHURST, supra note 15, at 10-11 (noting that there is "no one space where we feel at home all the time," and defining belonging in terms of Bordieu's notions about "how people ... feel comfortable or not in any one place").

20. For Huggan, supra note 15 , at 4 , there are

places on the planet where we belong and they are not necessarily where we are born. If we are lucky ... we find them, ... [and] ... know that ... we belong to the earth and it to us. Even if we cannot articulate this intense physical sensation, ... we know what home is then, in our very bones." She likens this "magnetic ... hormonal pull" to "carnal knowledge of landscape.

Id.

21. DiAne ACKerman, A NATURAl History OF the SENSES 20 (1990) (describing the feeling while scuba-diving that "[h]ome was everywhere" since "we carry the ocean within us; ... 
culture or identity. ${ }^{22}$ Belonging is especially salient in a discussion of migration, since the word itself captures the potential schism of "being" from "longing" - of physical location in a set of socio-political coordinates that may not correspond to one's own experienced or imagined place - as well as the felt (or compelled) need to bridge that gap. My goals here are to supplement (not supplant) discourses of culture and identity, and to liberate 'belonging' from its traditional association with the dark range of the membership spectrum.

At the primordialist extreme, belonging is an exclusionary concept based on notions of shared culture and ascribed identity, and is often ${ }^{23}$ though not necessarily ${ }^{24}$ synonymous with nationalism. The primordial or essentialist view-which has an affinity with "international legal norms against dual nationality" 25 based on the presumption of exclusive attachment - has fallen out of favor with many social scientists, ${ }^{26}$ despite the persistence of ethnic violence, religious fundamentalism, and national or sub-national self-determination

our veins mirror the tides").

22. See, e.g., QUESTIONS OF CUlTURAL IDENTITY (Stuart Hall \& Paul du Gay eds., 1996) [hereinafter QUESTIONS OF CULTURAL IDENTITY); HEDETOFT \& HJORT, supra note 16; Heisler, supra note 5; LOVELL, supra note 1; Orchard, supra note 15; Jo Shaw, The Interpretation of European Union Citizenship, 61 MOD. L. REV. 293 (1998); WOLFF, supra note 4.

23. Belonging may be predicated on "possession of a shared culture." Bellamy, The Making of Modern Citizenship, supra note 9, at 9. As an ideal type, "belonging" generally implies a national community, but not necessarily an ethno-national one. Thus, for example, Article 2 of the European Convention on Nationality defines 'nationality' as "the legal bond between a person and a State and does not indicate the person's ethnic origin." Council of Europe, European Treaty Series, no. 166, 6 November 1997 [hereinafter European Convention on Nationality]. Franck, supra note 12, at 362, uses the terms 'nation' and 'tribe' to mean "an affinity group that has placed certain values high on its agenda: shared genealogical origins, language and historic myths, as well as cultural and, perhaps, religious compatibility." He argues that nations, as a form of political identity, are forged in "a continual ebb and flow of differing, little-understood imperatives that at various times and circumstances rearrange the self-image of persons and thereby provoke revision of the boundaries of political communities." Id. at 365 . For the view linking nationalism with intolerance, see, for example, Hedetoft \& Hjort, supra note 16, at ix ("[T] he politics of belonging has always spelled unadulterated racism and national chauvinism" on the political right); MICHAEL IGNATIEFF, supra note 15 .

24. Franck, supra note 12 , at 365 , cites contemporary Israel for the proposition that nationalist origins of a State are compatible with multiethnicity.

25. Koslowski, supra note 12 , at 204 . "The phenomenon of dual nationality challenges traditional notions of political identity and ... basic assumptions of the classical European states system." Id. Koslowski does not merely argue that this prohibition reflects the Westphalian system, but that "[i]nternational norms against statelessness and dual nationality helped establish [it] by delineating its parts in terms of population." Id. at 207 (emphasis added). However, this traditional prohibition is eroding. Id. at $205,208-13$.

26. Indeed, "most modern sociologists and historians ... tend to believe that there "is no firm sociological mooring to the nation, not in language, not in religion, not in ethnicity." Franck, supra note 12, at 364 (quoting John A. Hall, Nationalism: Classified and Explained, DAEDALus 1, 4 (Summer 1993)); see also CROUCHER, supra note 1, at 38-39 (summarizing constructivist critiques of primordialism); Suzanne Shanahan, Different Standards and Standard Differences: Contemporary Citizenship and Immigration Debates, 26 THEORY \& SOC'Y 421, 421 (1997) ("Ethnicity, like any other social category, is a political construction that is less representative of palpable social distinctions or individual and collective differences than it is a particular historical manifestation of the boundary between states and peoples."). 
movements in our times. ${ }^{27}$

At the opposite constructivist extreme, belonging is inclusive ${ }^{28}$ and voluntary, ${ }^{29}$ and reflects the notion that identity is malleable $\mathrm{e}^{30}$ and compound. ${ }^{31}$ This view is compatible with the notion that healthy people may have multiple identities $^{32}$ and loyalties, and thus that little harm, and maybe even some good can come of dual nationality. In fact, the truth of most individual lives will lie somewhere between the extremes of prescription and choice.

My use of the term 'belonging' incorporates both internal and external aspects, that is, the "socially constructed, embedded process in which [particular] people reflexively judge the suitability of a given site as

27. Some who perceive the constructivist approach as inadequate to explain the "powerful and seemingly irrational passion and sense of embeddedness that often surround identity" propose a hybrid "constructed primordiality" approach. CROUCHER, supra note 1, at 39.

28. Franck, supra note 12 , at 362 , draws a sharp contrast between the constructivist term 'state' and the primordialist terms 'nation' and 'tribe.' "[T]he multicultural state reflects quite different social values: a civil society sharing a preference for the civic virtues of liberty and material well-being, as well as a desire to associate for protection and security." Id. The term "national identity" can thus refer simply to a "common civic consciousness and allegiance to the state and one's fellow citizens" such as may be cultivated through "[n]ational systems of education." Bellamy, supra note 9, at 7. See, e.g., Cécile Laborde, Republican Citizenship and the Crisis of Integration in France, in BELLAMY ET AL., supra note 9, at 46.

29. 'Voluntary' in this context must be understood as constrained, since belonging is not simply a matter "of individual choice, but rather the confluence of state laws and policies regarding the ascription, acquisition, and renunciation of nationality." Koslowski, supra note 12, at 214 .

30. "Distinctly different tribes or nations, for historic reasons and to different degrees, do sometimes merge their identities and submerge their origins, opting to become partly or entirely assimilated into a larger tribe/nation identity." Franck, supra note 12, at 367. Bauman argues that "the modern 'problem of identity' was primarily how to construct an identity and keep it solid and stable," whereas the "postmodern 'problem of identity' is primarily how to avoid fixation and keep the options open." Zygmunt Bauman, From Pilgrim to Tourist; or, A Short History of Identity, in QUESTIONS OF CULTURAL IDENTITY, supra note 22, at 18.

31. Multiple identities and loyalties are not, however, an innovation of our time. Indeed, "persons have often had multiple or compound identities" in the past. Franck, supra note 12, at 359. "Except during the latter part of the nineteenth and most of the twentieth centuries, it was normal for persons ... to define themselves by multiple loyalties." Id. at 377 (citing examples from the Roman, Ottoman, and Holy Roman Empires). Historically, however, individuals did not choose their multiple loyalties, but these were rather "imposed on [them] by virtue of who they were and where they lived." Id.

32. "Identities are not like hats. Human beings can and do put on several at a time." LINDA COLLEY, BRITONS 6 (1992). Contemporary European conditions are marked by the development of "a more diffuse and fragmented set of attachments that are both sub-national and transnational in character .... The ties of family, work, identity, religion and sport, for example, increasingly operate either below or beyond the nation-state, competing with and diluting any sense of a purely national identity." Richard Bellamy \& Alex Warleigh, Introduction: The Puzzle of European Citizenship, in CITIZENSHIP AND GOVERNANCE IN THE EUROPEAN UNION 3, 5 (Richard Bellamy \& Alex Warleigh eds., 2001) [hereinafter Bellamy \& Warleigh and BELLAMY \& WARLEIGH respectively]. Unlike multiple or compound identities in prior historical contexts, "[t]oday a person's loyalty system is increasingly likely to be a compound of subjectively chosen external references." Franck, supra note 12, at 362 . However, multiple identities cannot simply be assumed-not even from the fact of dual nationality, which is ambiguous. As Koslowski points out, dual nationality "may be an actualization of multiple political identification," supra note 12, at 216 , but it may also "be indicative of neither assimilation nor homeland political identification, but rather of ... an ambivalent political identity, or even an apolitical identity." Id. at 215. 
appropriate" 33 in view of their own circumstances, as well as the process by which others in that site judge the appropriateness of their presence there. These internal and external aspects imply a two-way process based on mutual adaptation and tolerance. In the end, belonging is not limited to either the nation or the state for its frame of reference, but incorporates social and psychological dimensions as well.

German history, at least since unification in the late nineteenth century, reveals an abiding preoccupation with the question of who belongs to or in Germany. ${ }^{34}$ This issue was omnipresent during the twentieth century. ${ }^{35}$ Migration and its consequences emerged after 1989 as a "leading political, social, and cultural issue" ${ }^{36}$ in Germany, as elsewhere in much of Europe, when the collapsing bi-polar postwar order and new wars-both inside Europe and beyond its borders-set even more migrants into motion. ${ }^{37}$ Though traditionally a sending country, Germany has in fact become one of the largest migrant-receiving countries in the world, ${ }^{38}$ and continues to wrestle with the challenges posed by its changing population and by the persistent demographic pressures to allow and even solicit further immigration. ${ }^{39}$

Germany and the European Union ("EU") have both scrambled to provide an adequate legal framework for this changing human landscape. The EU has

33. SAVAGE, BAGNALL \& LONGHURST, supra note 15, at 12. These authors also stress that belonging is "not a given but is itself unstable." Id. at 11 . For "newcomers [who] seek to construct a place that they can again call home," they must engage in "negotiations with neighbours." CASTLES \& DAVIDSON, supra note 15 , at 130 .

34. BRUBAKER, supra note 13; GOSEWINKEL, supra note 13; CHALLENGING ETHNIC Citizenship: German AND ISRAEli Perspectives on IMMIGRATION (Daniel Levy \& Y faat Weiss eds., 2002) [hereinafter ChALlENGING ETHNIC CITIZENSHIP]; Michael Minkenberg, The Politics of Citizenship in the New Republic, in GERMANY: BEYOND THE STABLE STATE 219 (Herbert Kitschelt \& Wolfgang Streeck eds., 2004); ElI NATHANS, THE POlitics OF CitizenshIP IN GeRMANY: ETHNICITY, UTILITY AND NATIONALISM (2004); Preuß, supra note 13; see also Franck, supra note 12, at 374 (referring to German "romantic nationalism and its tribal definition of the nation").

35. Id.

36. Tobias Brinkmann, German Migrations: Between Blood and Soil, 20 GERMAN POL. \& SoC'Y 137, 137 (2002) [hereinafter Brinkmann, German Migrations].

37. See Migration Policy Institute, Migration Information Source: Global Data Center (showing stock of foreign population in Germany by country of nationality by year; inflow of foreign population by country of nationality; top ten sending countries to Germany by nationality; and related data), available at http://www.migrationinformation.org/GlobalData (last visited Nov. $21,2005)$.

38. See Minkenberg, supra note 34, at 220 ("[B]etween 1954 and 1999, Germany became one of the largest immigrant-receiving countries in the world; the net balance of nine million immigrants during this period accounts for more than ten percent of today's population."). This accepted wisdom has recently been challenged by revised official statistics, which purport to have cleaned up the registry of foreign nationals in Germany. According to the revised statistics, only 6.7 million non-German nationals were legally residing in Germany at the end of 2004. Deutschland: Bereinigtes Ausländerregister [Germany: Sanitized Alien Registry], 5 MIGRATION UND BEVÖLKERUNG 1 (June 2005) [hereinafter Bereinigtes Ausländerregister].

39. See Minkenberg, supra note 34 , at 220; GÜNTER RENNER, STAATSANGEHÖRIGKEITSRECHT IM ZEICHEN DES NEUEN ZUWANDERUNGSRECHTS [CITIZENSHIP LAW UNDER THE NEW IMMIGRATION LAW] (Oct. 2004), at 4, MigRATIONSRECHT.NeT (last visited Nov. $29,2005)$. 
moved gradually but nonetheless dramatically into this formerly exclusive area of Member State sovereignty and created an elaborate legal framework to address some of these pressing issues at the regional level. However, the EU's legal framework on nationality/citizenship and on migration remains a highly contested work in progress. Member States retain considerable room to legislate, along with great flexibility when it comes to implementing EU norms. For its part, Germany has passed comprehensive new legislation governing both nationality/citizenship ${ }^{40}$ and immigration ${ }^{41}$ within the past five years. Thus, at both the national and the supranational levels, dramatic legal reforms testify to the continuing salience of nationality, citizenship, and migration, and make it safe to predict that the question of belonging will remain at the forefront of elite as well as popular concern in Germany and in the EU well into the twenty-first century.

This article investigates the evolving notion of belonging through the lens of Germany's new frameworks for nationality/citizenship and migration. ${ }^{42}$ Given the quantity of EU activity in the fields under consideration here, European developments are also analyzed, though less for their own sake than for the sake of staking out the parameters within which Germany remains sovereign to act.

Throughout this article, the question of how concrete developments bear on larger questions about belonging will recur. I make two main arguments. First, however welcome Germany's dramatic legal reforms may be, they will not necessarily solve the problems such legislation was intended to address. With regard to the new German law governing nationality/citizenship, the experience of German Jews teaches, among other lessons, that the legal status of citizenship does not automatically resolve the question of belonging. Tolerance cannot be legislated, but must - and can - be learned, albeit with difficulty. ${ }^{43}$ While

40. The reform of German nationality/citizenship law is discussed infra in Part III.A.

41. The reform of German immigration law is discussed infra in Part III.B.

42. This article does not provide a rigorous comparative analysis of German developments, but does make occasional comparative references when doing so casts German developments into sharper contour. Numerous comparative analyses are available. See, e.g., FrOM MIGRANTS TO Citizens: MEMBERSHIP IN A CHANGING WORLD (T. Alexander Aleinikoff \& Douglas Klusmeyer eds., 2000); THE POLITICS OF IMMIGRATION IN WESTERN EUROPE (M. Baldwin-Edwards \& Martin Schain eds., 1994); CHRISTIAN JOPPKE, IMMIGRATION AND THE NATION-STATE: THE UNITED STATES, GERMANY, AND GREAT BRITAIN (1999); RIVA KASTORYANO, NEGOTIATING IDENTITIES: STATES AND IMMIGRANTS IN FRANCE AND GERMANY (Barbara Harshav trans., 2002); Challenging Ethnic CitizenshiP, supra note 34; Liza Schuster \& John Solomos, Rights and Wrongs Across European Borders: Migrants, Minorities and Citizenship, 6 CITIZENSHIP STUD. 37 (2002) (analyzing Britain, France, Germany and Italy); Dietrich Thränhardt, Einwanderungs- und Integrationspolitik in Deutschland und den Niederlanden [Immigration and Integration Policy in Germany and the Netherlands], 30 Leviathan, June 2002, at 220; Patrick Weil, Access to Citizenship: Comparison of Twenty-Five Nationality Laws, in CITIZENSHIP TODAY: GLOBAL PERSPECTIVES AND PRACTICES (T. Alexander Aleinikoff \& Douglas Klusmeyer eds., 2001) [hereinafter CITIZENSHIP TODAY].

43. "Germans have a certain joy about cultural plurality, but then there's this other intriguing thing .... To learn tolerance is difficult." Axel Honneth, quoted in Jeffrey Fleishman, Debate Over 
public opinion data from the 1990s showed an overall high degree of convergence between the values held by Germans and other Europeans, the data also provide some evidence that Germans may be less tolerant of diversity. ${ }^{44}$ Second, despite even the best intentions, some aspects of recent legal reforms in Germany have the potential to exacerbate rather than alleviate social tensions. While many affected persons in Germany welcome the new integration requirements, ${ }^{45}$ Germany's revamped legal regime has simultaneously set off a storm of debate that is unlikely to dissipate any time soon. ${ }^{46}$

Questions surrounding tolerance, multiculturalism, and the existence of 'parallel societies' have returned to the forefront of contemporary debates in Germany, particularly since the eruption of ethnic violence in the neighboring Netherlands in the summer of $2004^{47}$ and in France in October 2005. ${ }^{48}$ The recent wave of 'honor killing' (Ehrenmord) of Muslim women by family members ${ }^{49}$ and controversies over extremist preaching in mosques ${ }^{50}$ have kept

\section{Tolerance Hangs Over Germany, Los ANGELES TIMES, July 13, 2003, at A5.}

44. Germans were slightly more likely $(75.8 \%)$ to mention tolerance as an important value to teach children than other Europeans (74\%), and were also more likely to say they would like to like to have immigrants as neighbors $(17.1 \%)$ than other Europeans $(12.1 \%)$. Results were virtually identical on general questions about tolerance of minority groups. However, Germans endorsed diversity less enthusiastically (53\%) than other Europeans (64\%), and were less likely to find other religions "not disturbing" (76\%) than other Europeans $(83 \%)$. Haas, Roever \& Schmidt, supra note 2 , at 155-56. These results are hardly conclusive and are in dire need of updating, but are interesting insofar as they pinpoint the most salient differences the researchers uncovered between Germans and other Europeans in the available survey data.

45. See, e.g., Bereitschaft zur Integration [Readiness to Integrate], KOLNER STADTANZEIGER, Dec. 23, 2004, at 8 (Minister for Social Affairs in North Rhine-Westphalia seeks to counteract "wide-spread prejudice" among Germans by means of data showing a "great willingness to integrate," such as high demand to participate in German language classes).

46. The call for integration is not new, but was already part of German policy in the 1970s. Minkenberg, supra note 34, at 220 (citing the 1977 government report on immigration); see also Katharina Stankiewicz, Changing Immigration and Integration Politics in Germany (unpublished 2002 manuscript, on file with author) [hereinafter Stankiewicz, Changing Politics], at 8 (on the implementation of naturalization guidelines-Einbürgerungsrichtlinien-in 1977). What is new is the threatened loss of welfare benefits and even potential deportation of migrants who do not make concrete efforts to integrate. Timm Krägenow, Bundesamt siebt Zuwanderer aus [Federal Office Sifts Out Migrants], FIN. Times DeuTSCHLAND, Jan. 20, 2005, at 1. See generally Ulrike Davy, Integration of Immigrants in Germany: A Slowly Evolving Concept, 7 EUR. J. MIGRATION \& L. 123 (2005).

47. Violence erupted in the neighboring Netherlands after the murder of filmmaker Theo van Gogh by Islam extremists. See Niederlande: Serie von Anschlägen nach Mord an Filmemacher, [Netherlands: Series of Attacks Following Murder of Filmmaker], 9 MIGRATION UND BEVÖLKERUNG 1, 1 (Dec. 2004). The events in the Netherlands contributed to the renewal of integration debates in Germany, as well as to the discussion of integration at the EU level. See Deutschland: Neue Integrationsdebatte [Germany: New Integration Debate], 9 MIGRATION UND BEVÖLKERUNG 1, 1-2 (Dec. 2004); EU: Grundprinzipien zur Integrationspolitik [EU: Basic Principles on Integration Policy], 9 Migration UNd BevólKerung 3, 3-4 (Dec. 2004).

48. See, e.g., Craig S. Smith, Riots Spread from Paris to Other French Cities, NEW YORK Times, Nov. 6, 2005, at A13.

49. As of the end of 2005 , the latest such murder of a young Muslim woman in Germany by a family member occurred in Wiesbaden in June 2005. Zwangsheirat Thema im Bundesrat [Bundesrat Discusses Forced Marriage], 3SAT ONLINE, at http://www.3sat.de/bookmark/sendung/ 80388 (last visited Oct. 17, 2005). Before that, six such crimes occurred in Berlin during a four- 
these issues in the German headlines. The list of prominent German politicians who have declared multiculturalism a dead letter includes the new federal chancellor, Angela Merkel. ${ }^{51}$ Migrants in Germany thus remain in a precarious situation, despite legislative and other efforts to improve their conditions. The situation could polarize even further, as Germany moves ahead with plans to deport more than a hundred Muslim 'extremists'. 52 This already tense ethnocultural milieu is further strained by bleak economic conditions in Germany itself. $^{53}$

During tense times, it is important to ratchet up the exchange of ideas about the relationship between law and belonging. The lens of belonging, by drawing attention to the distance between rules and aspirations at the normative level, on the one hand, and conditions on the ground, on the other, navigates a dynamic middle course between the polar extremes of primordialist and constructivist approaches to the topics of citizenship and migration. ${ }^{54}$ At the same time, this

month period. Klaus Weisner, Ehrenmord-"honor crime" (March 2005), at http://www.dekomnetz.de (last visited Oct. 17, 2005). Between 1996 and 2004, around 45 such murders occurred in Germany. Wisebadener Ehrenmord kein Einzelfall [Wiesbaden Honor Killing Was Not an Isolated Case], HESSISCHES SOZIALMINISTERIUM, at http://www.sozialministerium.hessen.de/ca/i/bgv (last visited Oct. 17, 2005).

50. In 2004, a Berlin imam was caught on camera telling worshipers that Germans would "burn in hell" because they were non-believers. Ray Furlong, Germans Argue Over Integration, BBC NEws (Nov. 30, 2004), at http://news.bbc.co.uk/1/hi/world/europe/4056109.stm (last visited Nov. 29, 2005). The response to this event is discussed infra in note 289.

51. See, e.g., Werner Shiffauer, Die Türken, ein deutscher Glücksfall [The Turks: Germany's Lucky Break], FrankfurTer Allgemeine SonNTAGSzeitung, Nov. 28, 2004, at 31 (quoting Merkel's reference to the "grandiose failure of multiculturalism"). Former Chancellor Helmut Schmidt caused further furor by suggesting that the decision to invite guest workers to Germany in the 1960s had been a mistake. Furlong, Germans Argue Over Integration, supra note 50.

52. Islamisten droht Ausweisung [Islamists Face Deportation], FRANKFURTER RUNDSCHAU, Jan. 24, 2005, at 4 . The threatened deportations are being pursued by the Länder - not by the federal government - on the basis of changes in the new immigration law, which has been in effect since January 1, 2005. Another potential source of destabilization, at least among the large Turkish population living in Germany and elsewhere in the EU, has been forestalled by the EU's October 2005 decision to open accession (that is, membership) negotiations with Turkey. EU Opens Historic Accession Talks with Turkey, EUOBSERVER.COM (Oct. 3, 2005) (last visited Oct. 17, 2005).

53. The Hartz IV reforms that took effect in January 2005 have radically reformed and reduced welfare benefits, and pushed the number of registered unemployed in Germany past the five million post by February 2005. Arbeitslosigkeit auf Rekordhoch [Unemployment at a Record High], FAZ.NET (Feb. 2, 2005) (last visited Oct. 17, 2005). The last time Germany saw such high unemployment was during the Great Depression. Fünf Millionen [Five Million], FAZ.NET (Feb. 2, 2005) (last visited Oct. 17, 2005).

54. By aiming to avoid the excesses of both primordialist/cultural and constructivist/identity approaches to the matter of membership, I do not claim that such approaches are necessarily flawed. Indeed, some of the most compelling contemporary accounts of European developments are framed in terms of identity. See, e.g., Shaw, supra note 22, at 294 (focusing on "the interaction between a narrow and formal legal concept of citizenship ... and a broader notion of 'membership' comprising constitutional, political and socio-economic elements in a multilevel (non-state) polity which is developing under post-national conditions involving fractured (state and individual) identities"). However, cultural and identity-based approaches often suffer from conceptual vagueness. They pose methodological dangers as well. For example, cultural approaches can fall prey to overdetermination or reification, whereas identity-based approaches may privilege agency over more immutable structural factors. Some particularly meticulous observers of European integration argue 
approach helps to denature the notion that attachments form primarily, if not solely at the level of the nation. This aspect renders belonging congenial for examining developments in the EU and in Germany that are driving a wedge between nationality and citizenship, between the nation and the state. ${ }^{55}$ But while national identity in Germany appears to be in decline, ${ }^{56}$ it is too soon to predict whether it will stand its ground or yield to other forms of sub- or supranational attachment. The lens of belonging offered here turns away from such ultimate questions and looks instead at different levels where it may be experienced and constructed, ranging from the family through group, city, ${ }^{57}$ community and nation, to international society ${ }^{58}$ and beyond. Belonging, understood as the experience or practice of embeddedness, may become more salient as rights migrate 'upward' from the local communities that first granted them ${ }^{59}$ towards increasingly abstract entities.

I turn now to a concrete examination of the legal frameworks within which belonging must be negotiated. This article proceeds by first providing a conceptual framework and addressing European-level developments pertaining to nationality/citizenship (Part II.A) and migration (Part II.B), then turns to

that "[c]ulture and identity are useful concepts only to delineate the baseline of a process ... that constitutes the single most striking case of wholly peaceful and voluntary political change in world history. They are not useful for describing and analyzing that phenomenon." Haas, Roever \& Schmidt, supra note 2, at 151.

55. See, e.g., Joppke, supra note 2, at 53-54:

The picture that ... emerges is that of the dissociation of state and nation in the liberal state's membership policies. States certainly continue to be 'nation-states', identifiable by a name like an individual, and embodying a unique history and collectivity. However, they have become wide open for new entrants, who can no longer be included or excluded on the basis of ascribed group characteristics, but only as individuals.

This trend marks a departure from the traditional view of the "powerful and assumed relationship" between belonging (understood as membership in the nation) and rights (understood as membership in the state). DAVID JACOBSON, Rights ACROSS BORDERS: IMMIGRATION AND THE DECLINE OF CITIZENSHIP ix, 107 (1996).

56. According to the public opinion data analyzed by Haas, Roever \& Schmidt, supra note 2, at 154-55, Germany (like other European countries) is experiencing a decline in the salience of national identity. Conversely, Germans are more likely than other Europeans to claim European identity.

57. For example, a recent immigrant to the U.S. from Kazakhstan joined the U.S. military after the September 11 attacks, explaining that it "doesn't matter that America is not my country. New York is my city." War on Terror: Perspectives, NewsweEk, Nov. 5, 2001, at 25. See also SAVAGE, BAGNALL \& LONGHURST, supra note 15 (on local belonging and attachment).

58. See generally INTERNATIONAL SOCIETY AND ITS CRITICS (Alex J. Bellamy ed., 2005) (surveying debates in the field of international relations); URRY, supra note 18, at 6 (providing a sociological perspective and arguing that contemporary challenges to traditional notions of "'nationstate-society' ... suggest that maybe Thatcher was oddly right when she said there is no such thing as society").

59. The rise of international and supranational human rights law is discussed infra in Part II.A.1. It bears mention here that, although states are becoming less essential as a source of rights, they remain "critical as the mediating mechanism, the node, of a variety of international institutions and global processes .... [1]t is primarily through the state that international human rights law is realized (and contested), and it is through the state that different groups and organizations (or individuals) can seek to shape interpretations of that law." JACOBSON, supra note 55, at X. 
consider the recent changes in German law on nationality/citizenship (Part III.A) and on migration (Part III.B). The discussion of integration in Part IV provides the common thread that ties the two strands of analysis in Parts II and III together. The emerging integration paradigm evidences a pragmatic approach to both the internal and external dimensions of belonging, but also contains the seeds of future conflict.

II.

FRAMING GERMAN DEVELOPMENTS

\section{A. BELONGING TO: NATIONALITY AND CITIZENSHIP}

\section{Overview}

'Nationality' and 'citizenship' both capture fundamental aspects of the content and meaning of belonging. Unfortunately, neither of these terms can lay claim to a clearly bounded definition. Moreover, these English terms are often treated as synonymous, when in fact they refer to different, albeit overlapping, statuses. Some official EU languages use the same term for both concepts, whereas others, including English, employ different terms. ${ }^{60}$ The task of defining and delineating the English terms 'nationality' and 'citizenship' poses a major threshold challenge to any inquiry in this field. This difficulty is compounded when one grafts a transnational or supranational dimension onto the territory-based system in which these phenomena emerged. Thus, an attempt at conceptual clarification must precede any examination of recent developments in the EU and in Germany.

Nationality is the traditional international legal term that refers to the link between an individual and a state. ${ }^{61}$ International law leaves questions of nationality largely up to each country, which can "settle by its own legislation the rules relating to the acquisition of its nationality, and to confer that

60. For a detailed analysis of the terminology corresponding to these two English terms in other EU languages, along with a comparison of how these terms are used in England, Ireland, and the United States, see Gerard-René de Groot, Towards a European Nationality Law, 8.3 ELECTRONIC J. COMP. L. 1, 2 (October 2004), available at http://www.ejcl.org (providing detailed etymological analysis of the terminology used in all EU member states) (last visited Nov. 29, 2005). Yet de Groot notes that despite the existence of parallel terminology in various languages (including the German terms Staatsangehörigkeit and -bürgerschaft), the "relationship between these two concepts ... is not fully clear." Id. at 2-3.

61. See, e.g., RESTATEMENT (THIRD) OF THE FOREIGN RELATIONS LAW OF THE U.S. § 211 cmt. a (1987) ("[T]he principal relationship that links an individual to the state is nationality."). I refrain from using the term nation-state since "there are very few states that consist of a single nation or ethnie." Franck, supra note 12, at 360. Nationality has also been described as “citizenship's external face." Alex Warleigh, Purposeful Opportunists? EU Institutions and the Struggle over European Citizenship, in BELLAMY \& WARLEIGH, supra note 32, at 19, 24. See also Alice Ludvig, Why Should Austria be Different from Germany? The Two Recent Nationality Reforms in Contrast, 13 GERMAN POLITICS 499, 500 (2004) ("[T]he rules on naturalization ... are the institutional expression of who is to be included and who is to be excluded from membership in the demos."). 
nationality by naturalization granted by its own organs in accordance with that legislation." 62 This explains why questions of nationality have thus far $^{63}$ been regulated by domestic legislation, such as the Immigration and Nationality Act in the United States. ${ }^{64}$ Under international law, nationality implies a host of rights and obligations for the individual, including "being subject to a nation's laws, its taxes, and military conscription while enjoying the right of protection by the state even when abroad." 65 Whereas this term is still commonly used in English, particularly in international legal discourse, it has fallen into disrepute in some Continental countries, where it evokes abhorrent ethnic notions of nationalism.

Citizenship is a tougher notion to grasp because it lies at the intersection of law, social science, and political theory. Whereas the meaning of nationality has remained relatively stable within the so-called Westphalian system from which it emerged, the meaning of citizenship has evolved over time and differs from place to place. ${ }^{66}$ Citizenship implies "full membership" in a political community. ${ }^{67}$ Before the state emerged as the predominant form of political organization, citizenship referred to membership in smaller governmental units and implied the rights enjoyed by, as well as the duties imposed on, those lawful residents who were entitled to the status of citizen. ${ }^{68}$ Later, in the Westphalian

62. Nottebohm Case (Liech. v. Guat.), 1955 I.C.J. 4, $20-21$ (Nov. 29, 1955); see also, RESTATEMENT (THIRD) OF THE FOREIGN RELATIONS LAW OF THE U.S. \& $211 \mathrm{cmt}$ c (1987) ("A state is free to establish nationality law and confer nationality as it sees fit."). However, international law does impose some limits on each state's sovereignty in regard to nationality. Thus, "other states need not recognize a nationality that is involuntary... or that is not based on an accepted 'genuine link."' $I$.

63. De Groot, supra note 60 , at 20 suggests that the EU is on its way to adopting a common nationality law. Others "emphasize the enduring importance of nationality, in opposition to the thesis of a postnational age in which state membership is fading in significance, eclipsed by the rise of transnational identities and human rights protections." Gerald L. Neuman, Book Review, 96 AM. J. INT'L L. 514, 514 (2002).

64. Immigration and Nationality Act, 8 U.S.C. $\S \S 1101-1537$ (2000). Section 1103(a)(3) defines "alien" as "any person not a citizen or national of the United States." A U.S. "national" is a person who is either " $(\mathrm{A})$ a citizen of the United States, or (B) ... who, though not a citizen of the United States, owes permanent allegiance to the United States." §1101(a)(22).

65. Koslowski, supra note 12, at 205.

66. Bellamy, The Making of Modern Citizenship, supra note 9, at 5, doubts whether "a history of the concept from ancient Greece to the present could plausibly be written," given that:

[T] he term 'citizen' has had different meanings in different historical periods and languages. It can signify the member of a city and/or a given class, as in the Greek polities or the original usage of the German Staatsbuerger, or be equated with subjecthood of a monarchy, as in Britain, or membership of a state, as in France, or be associated primarily with belonging to a people or nation, as was the case in Germany. Id.

67. Shaw, supra note 22 , at 297 (noting that citizenship is not merely a "formal legal status").

68. Maarten Prak, Burghers into Citizens: Urban and National Citizenship in the Netherlands during the Revolutionary Era (c. 1800), 26 THEORY \& SOC'Y 403 (1997). These historical origins explain the high level of variance that prevailed from one govemmental entity to another in the early conditions of citizenship. Tilly notes as well that the "rights and obligations linking citizens to states have formed through struggle." Charles Tilly, A Primer on Citizenship, 26 
system, citizenship came to mean membership in a particular state. This familiar meaning has come under increasing attack, particularly in the wake of the development of EU citizenship. ${ }^{69}$

The term citizenship itself can "denote a relationship to a polity, a social status, an activity, a package of rights, or a package of responsibilities."70 It is a sociological and political concept as well as a legal one. From the legal perspective, citizenship has been rooted in domestic law and has not traditionally been a concept of international law. ${ }^{71}$ In contemporary usage, the concept of citizenship serves as the marker for membership in democratic society, regardless of the form that the political community happens to take. Citizenship is an "institution which has... been developed and refined to nurture and protect" the homo politicus, who embodies the democratic expectation that individuals should "play a part in the social and political life of the society in which they reside." 72 Viewing citizenship solely through a legal or constitutional lens thus misses much of the "functional significance of the relevant polity for individual citizens." ${ }^{, 73}$ Consequently, it is relatively easy to pinpoint the legal content of citizenship, but much more difficult to fathom its political and social meaning. ${ }^{74}$

Citizenship is a "contested truth", that has in recent years enjoyed the

THEORY \& SOC'Y 599, 601 (1997); see also Pietro Costa, From National to European Citizenship: A Historical Comparison, in BELLAMY ET AL., supra note 9, at 207.

69. In order to render the evolving nature of political community, Tilly, supra note 63, at 600 , has proposed a more generic definition that does not limit citizenship to any particular type of governmental entity, but rather defines it as a "set of mutually enforceable claims relating categories of persons to agents of governments." While broad enough to capture some emerging forms of membership, Tilly's referential frame is too narrow to embrace all notions of citizenship found in contemporary discourse. In particular, there appears to be no room in Tilly's definition for discussions of cosmopolitan citizenship based on membership in international society. See, e.g. DANIELE ARCHIBUgi \& DAVID Held, COSMOPOLITAN DEMOCRACY: AN AGENDA FOR A NEW WORLd ORDER (1995); RE-IMAgINING POLITICAL COMMUNITY: STUdIES IN COSMOPOLITAN Citizenship (Daniele Archibugi et al. eds., 1998); David Held, DemoCracy and the Global ORDER: FROM THE MODERN STATE TO COSMOPOLITAN GOVERNANCE (1995). Moreover, Tilly's emphasis on "claims" misses the full range of practices involved in the construction of citizenship. See, e.g., Antje Wiener, Making Sense of the New Geography of Citizenship: Fragmented Citizenship in the European Union, 26 THEORY \& SOC'Y 529 (1997) [hereinafter Wiener, Fragmented Citizenship].

70. Neuman, supra note 63 , at 514.

71. RESTATEMENT (THIRD) OF THE FOREIGN RELATIONS LAW OF THE U.S. $\S 211 \mathrm{cmt} . \mathrm{h}$ (1987) (observing that not all States recognize this distinction).

72. Michelle Everson, The Legacy of the Market Citizen, in NEw LEgal DYNAMICS OF EUROPEAN UNION 73, 76 (Jo Shaw \& Gillian Moore eds., 1995) [hereinafter SHAW \& MOORE] (noting that citizen is "both governor and governed").

73. R.J. Barry Jones, The Political Economy of European Citizenship, in BELLAMY \& WARLEIGH, supra note 32, at 145 ("[T]he sets of legal definitions and provisions that endow individuals with formal membership of a polity are important, but remain only a small part of the picture of substantive and meaningful citizenship." (citations omitted)).

74. Everson, supra note 72, at 76; see also Rainer Bauböck, Recombinant Citizenship, Institute for Advanced Studies, Vienna Political Science Series No. 67 (1999) (distinguishing "thick" and "thin" conceptions of citizenship).

75. M.R. Sommers, Rights, Relationality and Membership: Rethinking the Making and 
attention of scholars from across the disciplinary spectrum. ${ }^{76}$ Despite the great range of opinion found in the massive literature on citizenship, most authors agree that citizenship includes, at the very least, the "bundle of civil, political, and social rights possessed by individuals" $" 77$ by virtue of their relationship to a governmental entity. However, this is an unsatisfactory definition of citizenship because it overlaps substantially with that of nationality. Thus, most authors take this rights-based definition as a starting point for their analysis of citizenship, then elaborate upon it by expanding on the list of rights granted ${ }^{78}$ or creating typologies that differentiate the internal structure of citizenship. ${ }^{79}$ Some authors emphasize the important distinction between passive ${ }^{80}$ and active citizenship, and draw attention to the constitutive role of practices, ${ }^{81}$ while still

Meaning of Citizenship, 19 L. \& SOC. INQUIRY 63, 64 (1994).

76. Even the best legal scholars recognize the need for an interdisciplinary approach to the study of European citizenship. See, e.g., Shaw, supra note 22, at 309-10. However, Shaw has also observed that "lawyers... were the first group of writers to begin to extrapolate concepts of citizenship out of the materials of what was then EEC law." Id. at 297 n.10. For examples of different frames of analysis, see CITIZENSHIP, DEMOCRACY AND JUSTICE IN THE NEW EUROPE (Percy B. Lehning \& Albert Weale eds., 1997); Symposium, Changing Citizenship Theory and Practice, 38 PS: POLITICAL SCIENCE \& POLITICS 667-99 (Oct. 2005); YASEMIN NuHOGllu SOYSAL, LIMITS TO CITIZENSHIP: MIGRANTS AND POSTNATIONAL MEMBERSHIP IN EUROPE (1994); Joseph H.H. Weiler, To Be a European Citizen: Eros and Civilization, in JOSEPH WEILER, THE CONSTITUTION OF EUROPE: "DO THE NEW Clothes HAVE AN EMPEROR?" AND OTHER ESSAYS ON EUROPEAN INTEGRATION 324 (1999) [hereinafter Weiler, Eros and Civilization]; Antje Wiener, The Embedded Acquis Communautaire: Transmission Belt and Prism of New Governance, 4 EUR. L.J. 294 (1998) [hereinafter Wiener, Embedded Acquis].

77. See, e.g., Koslowski, supra note 12, at 205. Here Koslowski, like most other experts on citizenship, invokes "the almost canonical approach to citizenship issues taken by the sociologist T.H. Marshall." Shaw, supra note 22, at 297 (quoting T.H. MARSHALL, CITIZENSHIP AND SOCIAL CLASS) (1950)). Everson argues that "entitlement by right" is the "core of citizenship," supra note 72 , at 84, and explains that "entitlements are the classic rights of citizenship, arranged in a series of concentric circles, with civil or civic rights forming the core, then political rights, and with social rights situated beyond these." $I d$. at 83 .

78. For example, Bauböck has argued that cultural citizenship constitutes a fourth kind of citizenship. Rainer Bauböck, Cultural Citizenship, Minority Rights and Self-Government, in CITIZENSHIP TODAY, supra note 42, at 319-48.

79. Bellamy, The Making of Modern Citizenship, supra note 9, identifies three components of citizenship (that is, rights, belonging, and participation), whereas Jones claims that citizenship has formal, instrumental and affective facets that provide the "foundations of effective polities." Jones, supra note 73 , at $144,146$.

80. Bellamy, The Making of Modern Citizenship, supra note 9, at 7, stresses the distinction between citizenship and "mere subjecthood," which I understand as a form of passivity or nonagency. See also Preuß, supra note 13, at 23 ("As part of the evolution of modern statehood, nationals changed from being mere passive subjects of the nation-state in which they lived to become active citizens who constituted the state-as-nation."). This semantic distinction appears to have a rough parallel in the field of public international law, where some experts similarly reject the term "subjects of" international law, and use the term "persons in" international law instead. See Introductory Note to Part 2 of RESTATEMENT (THIRD) OF FOREIGN RELATIONS LAW (cautioning against use of the term "subject" since it "may have more limited connotations, suggesting that such entities have only rights and obligations," whereas "entities that are persons under international law ... have legal status, personality, rights, and duties under international law").

81. See, e.g., Richard Bellamy, The 'Right to Have Rights': Citizenship Practice and the Political Constitution of the EU, in BELLAMY \& WARLEIGH, supra note 32, at 41-70 [hereinafter Bellamy, Citizenship Practice]; Riva Kastoryano, Citizenship and Belonging: Beyond Blood and 
others proceed by recognizing and analyzing further dimensions of citizenship, such as its relational character ${ }^{82}$ or its normative nature, ${ }^{83}$ that help to distinguish it from mere nationality. Thus, the contemporary understanding of citizenship refers less to an overarching status, than to a set of rights and obligations that the individual must negotiate across various levels of governance, from concrete local communities and institutions on up to higher levels of abstraction.

With these basic definitions in place, we can now reconsider the relationship between nationality and citizenship. First, as already noted, the two concepts overlap in terms of their content since rights and duties play a central role in defining each term. Second, in the Westphalian system, where the state is understood as the main source of rights and personal identity, ${ }^{84}$ nationality and citizenship may be, but are not necessarily identical in the formal legal sense. Nationality is in one sense broader and more inclusive, since it is a necessary but not always sufficient condition for citizenship. Thus, "every citizen is a national, but not every national is necessarily a citizen of the State concerned." ${ }^{, 85}$ For example, corporations, ships and aircraft possess nationality but do not possess citizenship. 86 This may also be true of individuals in some countries. For example, not all British nationals enjoy the privileged status of British citizen, ${ }^{87}$ nor do all American nationals enjoy full rights of citizenship. ${ }^{88}$

Soil, in HEDETOFT \& HJORT, supra note 16, at 120-36; Warleigh, supra note 61; Wiener, Fragmented Citizenship, supra note 69.

82. Tilly, supra note 68 , at 600 (arguing that citizenship "has the character of a contract: variable in range, never completely specificable, always depending on unstated assumptions about context, modified by practice, constrained by collective memory, yet ineluctably involving rights and obligations sufficiently defined that either party is likely to express indignation and take corrective action when the other fails to meet expectations built into the relationship").

83. The normative aspect of citizenship "concerns the manner in which people feel their particular community should be organized." Everson, supra note 72 , at 80 . See, e.g., Bellamy, Citizenship Practice, supra note 81; LEHNING \& WEALE, supra note 76; Nikos Prentoulis, On the Technology of Collective Identity: Normative Reconstructions of the Concept of EU Citizenship, 7 EUR. L.J. 196 (2001); Shaw, supra note 22, at 294, 315.

84. "Since the Reformation, the Peace of Westphalia and the writings of Hugo Grotius, the state has been the alpha and omega of petsonal identity." Franck, supra note 12, at 360 .

85. Paul Weis, Nationality and STATElESSNESS IN INTERNATIONAL LaW 5-6 (1979); see also RESTATEMENT (THIRD) OF FOREIGN RELATIONS LAW § $211 \mathrm{cmt}$. h (1987) ("A citizen under national law is generally a national for purposes of international law, but in some states not all nationals are citizens.").

86. Koslowski, supra note 12 , at 205 . The following discussion pertains only to individuals and does not explore further implications of nationality or citizenship for corporations, ships or aircraft.

87. For an overview of the various statuses recognized under the British Nationality Act, see de Groot, supra note 60 , at 2 and text accompanying note 7 (noting the categories of British Overseas Territories Citizen, British Overseas Citizen, British Subject without Citizenship, and British Protected Person).

88. Currently, persons born in an outlying possession of the United States (that is, American Samoa and Swains Island) fall into this category. See Immigration and Nationality Act $\S 308$ (8 U.S.C. $\$ 1408$ (2000). Moreover, U.S. felons may lose their citizenship rights, but still retain their nationality. Koslowski, supra note 12, at 205. Historically, Black Americans were treated as noncitizen nationals prior to the adoption of the Fourteenth Amendment. See, e.g., Dred Scott v. 
As these examples show, citizenship may constitute a narrower and more exclusive category, or subset, of nationality, when viewed in terms of membership. Yet in such cases, citizenship simultaneously implies a broader range or greater quantum of rights and duties than those attached to mere nationality, when viewed in terms of its content. ${ }^{89}$ In addition, neither nationality nor citizenship inherently requires that the relationship between individual and state be an exclusive one. Rather, the Westphalian presumption of singular allegiance is an historical artifact of relatively recent modernist origin. "Human beings for millennia have defined themselves in terms of loyalty to more than one system of social and political organization." 90 This stricture of the Westphalian system began eroding after World War II and was noticeably diminished by the turn of the millennium, though it still retains considerable force. $^{91}$

Citizenship, like nationality, is still largely defined with reference to the state, despite the advance of new forms of belonging. It has, however, taken on a wealth of post-Westphalian meaning, particularly since its formal introduction at the EU level by the 1992 Maastricht Treaty on European Union ("TEU"). ${ }^{92}$

Sandford, 60 U.S. (19 How.) 393, 404-05 (1857).

89. This distinction roughly parallels the one under international law between absolute and relative human rights, where "absolute rights are rights that everyone has against everyone else," while relative rights are those "that every member of every legal community has in her respective legal community." Rut Rubio Marin \& Rory O'Connell, The European Convention and the Relative Rights of Resident Aliens, 5 EUR. L.J. 4, 4 (1999). For example, the European Convention on Human Rights accords "some rights to all persons within the jurisdiction of the state, but reserves certain rights for the nationals of each country." Id. at 5; see European Convention for the Protection of Human Rights and Fundamental Freedoms, Nov. 4, 1950 (ETS No. 5), 213 U.N.T.S. 222, entered into force Sept. 3, 1953, as amended [hereinafter ECHR]; see also International Covenant on Civil and Political Rights, Dec. 16, 1966, G.A. Res. 2200A (XXI), 21 U.N. GAOR Supp. (No. 16) at 52, U.N. Doc. A/6316 (1966), 999 U.N.T.S. 171, entered into force Mar. 23, 1976.

90. Franck, supra note 12, at 370 . In Western Europe, the "common accommodation of multiple loyalties ... generally ceased in late Tudor England and in the Sun King's France, when the state became sovereign and the sovereign became the state." Id. at 371. The French and American revolutions substituted "horizontal" loyalty to the sovereign people for "vertical" personal fealty to the monarch, and transformed individuals from subjects into citizens, but did not abandon the insistence on exclusive loyalty to one sovereign. Id. at 372 . In that historical context, the term 'nation' referred to the "new sovereign" constituted by "the people ... themselves, conjoined in liberty, equality and fraternity," and thus meant "something entirely different from its current usage." Id. In the late eighteenth century, "the state became the nation: not the nation of ethnic compatibility but the nation of kindred ideals." Id. Only towards the end of the nineteenth century were the terms 'nation' and 'nationalism' "appropriated" and "twisted into new loyalty patterns based on exclusive and xenophobic loyalty to myth-history, race, language, ethnie and culture. The French nation that emerged in 1789 was not even remotely related conceptually to the German nation created and led a century later by Prussia." Id.

91. Franck, supra note 12; Koslowski, supra note 12; Peter J. Spiro, Dual Nationality and the Meaning of Citizenship, 46 EMORY L.J. 1411, 1413 (1997) (noting that the U.S. "has moved towards almost complete toleration of dual nationality"). German views on dual nationality are discussed infra in Part III.A.

92. Treaty on European Union, Feb. 7, 1992, 1992 O.J. (C 191) 1 [hereinafter TEU]. The TEU entered into effect on November 1, 1993. A consolidated version containing subsequent amendments to the TEU is available at 2002 O.J. (C 325) 5. 
Contemporary practices of citizenship are "increasingly decoupled from belonging in the national collective" and occur in a proliferating number of sites. $^{93}$ As the state's role as exclusive provider of rights characteristic of citizenship declines, ${ }^{94}$ the breach between nationality and citizenship widens.

\section{Nationality and Citizenship in the European Union}

EU citizenship demonstrates both continuity and rupture with the prevailing Westphalian system. This section offers an overview of the nature and content of this complex phenomenon. My aims here are to identify key continuities and discontinuities, and to pinpoint areas where further developments are brewing, in order to illuminate the shifting parameters within which Germany and other FU Member States remain sovereign over matters pertaining to nationality and citizenship. Article 17 of the EC Treaty provides:

Citizenship of the Union is hereby established. Every person holding the nationality of a Member State shall be a citizen of the Union. Citizenship of the Union shall complement and not replace national citizenship. ${ }^{5}$

On its face, this formulation reveals a fundamental continuity between state-based and EU citizenship. Additional continuities, along with a number of important discontinuities, can be discerned upon further analysis of the nature and content of EU citizenship. Particular care must be taken to differentiate these facets of EU citizenship, since they reflect and are thus key to appreciating the EU's sui generis nature, ${ }^{96}$ which combines characteristics of international

93. Yasemin Nuhoğlu Soysal, Citizenship and Identity: Living in Diasporas in Postwar Europe?, in HEDETOFT \& HJORT, supra note 16, at 137, 139; see also Veit Bader, Citizenship and Exclusion: Radical Democracy, Community, and Justice. Or, What's Wrong with Communitarianism?, 23 POL. THEORY 224 (1995) (calling for "democratic citizenship ... to be disentangled from citizenship as state membership"); KASTORYANO, supra note 42, at 132 (observing the increasing "dissociation of citizenship from nationality").

94. Today, the "consolidated state remains the most important locus of rights," but is "no longer their only locus." Michael Hanagan, Recasting Citizenship: Introduction, 26 THEORY \& SOC'Y 397,399 (1997). This is particularly true in the EU, but can also be taken to refer to the increasing role of international law as a source of rights that might be characterized as pertaining to citizenship, such as the ECHR, supra note 89.

95. Treaty Establishing the European Economic Community, March 25, 1957, 298 U.N.T.S. 11, 4 EUR. Y.B. 412, as amended [hereinafter EC Treaty]. A consolidated version incorporating subsequent amendments to the EC Treaty-which is still often referred to as the Rome Treaty-is available at 2002 O.J. (C 325) 33. The first sentence of Article 17 was added as Article 8 to the preexisting EC Treaty by the 1992 Maastricht Treaty of European Union, supra note 92 . The second sentence of Article 17 was added by the Treaty of Amsterdam, which entered into force on May 1, 1999. Treaty of Amsterdam amending the Treaty on European Union, the Treaties Establishing the European Communities and Certain Related Acts, Oct. 2, 1997, 1997 O.J. (C 340) 1 [hereinafter Treaty of Amsterdam]. The Treaty of Amsterdam renumbered the citizenship provisions in the EC Treaty, with the effect that former Article 8 became Article 17. The Treaty of Nice, which entered into effect on February 1, 2003, did not alter the EC Treaty in regard to citizenship. Treaty of Nice amending the Treaty on European Union, the Treaties Establishing the European Communities and Certain Related Acts, Feb. 26, 2001, 2001 O.J. (C 80) 70 [hereinafter Treaty of Nice].

96. Curtin asserts that the "true world-historical significance" of this sui generis entity lies in its conferral of "rights on individuals." Dierdre Curtin, The Constitutional Structure of the Union: $A$ Europe of Bits and Pieces, 20 COMMON MARKET L. REV. 17, 67 (1993); see also Bellamy \& 
organizations with those found in different types of states. ${ }^{97}$ EU citizenship creates "schizophrenic" citizens who are simultaneously linked to "two divergent forms" of polity. ${ }^{98}$

\section{a. The Link Between Nationality and Citizenship}

The first and most overt continuity is that nationality remains a necessary precondition of EU citizenship, ${ }^{99}$ just as it is required in the context of the Westphalian state. EU citizenship also hews to tradition insofar as "the question whether an individual possesses the nationality of a Member State shall be settled solely by reference to the national law of the Member State concerned."100 Further continuity exists insofar as Member State nationality, while necessary, does not always suffice to confer EU citizenship. Thus, some persons possessing Member State nationality do not enjoy full membership in the EU. ${ }^{101}$ However, there are indications that these traditional foundations of EU citizenship are under strain and that "full [Member State] autonomy cannot be maintained ... in all circumstances."102

This pressure towards convergence with regard to nationality comes from various directions. First, the EU's expanding role in the field of immigration ${ }^{103}$ increases the practical need to devise common approaches to some aspects of nationality law, such as the treatment of stateless persons ${ }^{104}$ and rules on

Warleigh, supra note 32 , at 8 (noting the EU's "betwixt-and-between character").

97. Everson, supra note 72 , at 77 , suggests that a "tenuous analogy may be drawn between this supranational citizen/diluted alien and the federal/state citizen of orthodox constitutional government." See generally Peter Schuck, Citizenship in Federal Systems, 48 AM. J. CoMP. L. 195 (2000).

98. Everson, supra note 72 , at 77.

99. De Groot, supra note 60 , at 2 , points out that the meaning of the term "national citizenship" is unclear, but presumes that it refers to "possession and exercise of 'citizenship rights' at the national level."

100. Declaration (No. 2) on Nationality of a Member State, 1992 O.J. (C 191) 98. This principle is not contradicted by the existence of the optional European Convention on Nationality, supra note 23, which was prepared under the auspices of the Strasbourg-based Council of Europe. De Groot, supra note 60, at 30, urges the EU to "cooperate with the Council of Europe" in regard to harmonization of rules on acquisition and loss of nationality; Gerard-René de Groot, The European Convention on Nationality: A Step towards a lus Commune in the Field of Nationality Law, 7 MAASTRICHT J. EUR. \& COMP. L. 117 (2000).

101. See de Groot, supra note 60, at 8-9. De Groot claims that "Fidel Castro himself could immediately opt for European citizenship while continuing to reside in Cuba" by virtue of recent changes in Spanish nationality law. Id. at 10.

102. De Groot, supra note 60, at 10; see also A EUROPEAN NATIONALITY: CITIZENSHIP, Immigration and Nationality LAW IN tHE EU (Randall Hansen \& Patrick Weil eds., 2001). Numerous authors have called explicitly for decoupling Union citizenship from nationality. See generally Norbert Reich, Union Citizenship-Metaphor or Source of Rights?, 7 EUR. L.J. 4, 15-19 (2001) (summarizing the debate on this topic, including the possibility of taking residence as a central criterion for citizenship).

103. See the discussion of the emerging EU framework for migration, infra Part II.B.

104. European Parliament Resolution (Sept. 18, 1981) on the British Nationality Bill, 1981 O.J. (C 260) 100 (issued in connection with the British Nationality Act 1981). 
naturalization. ${ }^{105}$ For example, the 1999 Tampere Council ${ }^{106}$ endorsed the "long-term objective that long-term residents should be offered the opportunity to obtain the nationality of the Member State in which they are resident," and thereby also to gain EU citizenship. ${ }^{107}$ In line with that objective, the Commission-ostensibly "without prejudice to the fact that the Member States alone remain competent in the area of nationality laws"108 - subsequently prepared a report presenting its views in favor of naturalization as a means to promote further integration of legal immigrants. ${ }^{109}$ Second, evolving applications of the principles of non-discrimination and equality may drive further harmonization. For example, the existence of "striking ... differences" in the treatment of descendants of persons originating in the territory of the various Member States provides an occasion that may tempt EU institutions to limit Member State sovereignty in regard to nationality. ${ }^{110}$ The European Court of Justice ("ECJ") has already made clear that it will review Member State nationality laws to assess their compatibility with principles of Community law. ${ }^{11}$ While none of these sources of pressure spell the certain end of Member State sovereignty with regard to nationality, when taken together, they portend further development at the EU level and concomitant constraints on Member State action in this field.

105. De Groot, supra note 60 , at $20 \mathrm{n} .92$, points out that Article I, Section 8 , Clause 4 of the U.S. Constitution granted the Congress the power to "establish an uniform Rule on Naturalization," in order to prevent the States of the Union from developing different policies on naturalization and immigration. In contrast, other matters of nationality law, such as acquisition by birth and loss of nationality, were regulated by the States and not by the Federal Government until 1868, when the 14th Amendment came into force.

106. In October 1999, during the Finnish Presidency, the European Council held a special meeting to elaborate the "policy orientations and priorities" necessary to implement the Area of Freedom, Security and Justice ("AFSJ") that had been established by Article 2 of the Treaty of Amsterdam. Presidency Conclusions of the Tampere European Council (Oct. 15-16, 1999), Bull. EU 10-1999, ๆf I.3 - I.11, I 1.3.9 [hereinafter Tampere Milestones]. This special meeting of the European Council adopted the term "genuine European area of justice" to describe the telos of the justice component of the AFSJ. Id. $\mid$ I.8.

107. Commission of the European Communities, Fourth Report on Citizenship of the Union, COM (2004) 695 final (Oct. 26, 2004), at 4 [hereinafter Fourth Citizenship Report].

108. Fourth Citizenship Report, supra note 107, at 4.

109. Communication from the Commission to the Council, the European Parliament, the European Economic and Social Committee and the Committee of the Regions, Immigration, Integration and Employment, COM (2003) 336 final (June 3, 2003) [hereinafter COMMISSION COMMUNICATION ON IMMIGRATION, INTEGRATION AND EMPLOYMENT].

110. De Groot, supra note 60, at 21 (arguing that "[i]t will be difficult to continue to accept such unequal treatment").

111. De Groot, supra note 60, at 11-20, summarizes a number of cases in text accompanying notes 49-90. Among these is the 1992 Micheletti case, in which the ECJ stated that "[ $t$ ] he definition of the conditions of acquisition and loss of nationality is, in conformity with international law, within the competence of each Member State, which competence must be exercised with due regard to Community law." Case 369/90, Micheletti v. Delegación del Gobiemo European Cantabria, 1992 E.C.R. I-4258 (emphasis added). 


\section{b. The Centrality of Rights}

The second major continuity between EU and State-based citizenship comprises the centrality of rights in defining EU citizenship. ${ }^{112}$ Primary (that is, treaty) law is supplemented by a growing body of secondary legislation at the EU level. However, this perspective oversimplifies the picture in two respects. First, cataloging the formal legal rights that make up EU citizenship is just the first step towards comprehending this phenomenon. ${ }^{113}$ The picture of EU citizenship as a juridical status based on conferred rights is too limited. Rather, a holistic inquiry into the active, engaged citizen "as political being" is needed, ${ }^{114}$ given the proliferation of both individual and institutional practices that constitute EU citizenship in action. ${ }^{115}$ Second, while it is clear that Union citizenship supplements the rights of national citizenship, it is less clear to what extent it really improves the position already enjoyed by individuals under EC law. ${ }^{116}$ From this perspective, Union citizenship is "less than revolutionary [but] far from a dead letter."

A fully rendered portrayal of Union citizenship would require projecting its content against the double backdrops of Member State citizenship and the acquis communautaire. However, such a comprehensive analysis is beyond the scope of the following sketch of the contours of Union citizenship. In the narrow sense of provisions found in Part II of the EC Treaty, EU citizenship bestows four limited but nonetheless "genuine" 18 new rights upon nationals of

112. "Citizens of the Union shall enjoy the rights conferred by this Treaty and shall be subject to the duties imposed thereby." Article 17, EC Treaty, supra note 95 . To date, no concrete duties have been imposed on EU citizens. But see Reich, supra note 102, at 20-23 (discussing the notion of "duty of loyalty" and other concepts that might be used to limit individuals' rights).

113. Antje Wiener has traced "the roots of citizenship policy and actual citizenship practice ... over a period of about two decades ... since the early 1970s." Wiener, Fragmented Citizenship, supra note 69, at 537-38.

114. CROUCHER, supra note 1 , at $46-47$ (contrasting the legalistic Roman notion of citizenship with the political, Aristotelian view). A number of leading scholars on EU citizenship stress the importance of the political facet of citizenship. See, e.g., Bellamy, Citizenship Practice, supra note 81; Shaw, supra note 22, at 294 (EU membership is "an ideal type" based on "an active conception of social citizenship based on a politically defined community"); Warleigh, supra note 61 .

115. Citizenship is a "dynamic" concept, Wiener, Fragmented Citizenship, supra note 69, at 530 , that embodies "the institutional struggle over the development of the EU itself." Warleigh, supra note 61, at 21; see also Wiener, Embedded Acquis, supra note 76.

116. Many commentators on EU citizenship have examined whether, and if so, how and to what extent, it has altered the existing position of individuals under Community law. See, e.g., Everson, supra note 72; Reich, supra note 102; Shaw, supra note 22; Wiener, Embedded Acquis, supra note 76. For example, one leading author argues that EU citizenship departs from the "market citizen" role traditionally ascribed to the individual in the context of European integration. Everson, supra note 72, at 79 ("The forerunner to the Union citizen, the market citizen, was also distinguished as a bearer of rights vis-à-vis an international organization.").

117. Warleigh, supra note 61, at 23.

118. Fourth Citizenship Report, supra note 107, at 4. "Citizenship of the Union has developed over twelve years of existence into a source of real and concrete rights." Id. at 10. 
its Member States. ${ }^{119}$ Among them, the first merely extends the rights already existing under Community law, while the latter three constitute real innovations at the supranational level. In the broader sense, EU citizenship also comprises the emergence and development of rights based on an array of other treaty provisions and legal sources.

\section{i. Citizenship in the Narrow Sense: Rights Based on Part Two of the EC Treaty}

The first right laid down is the personal right to free movement and residence throughout the EU. ${ }^{120}$ This provision represents a de jure expansion of the free movement rights of workers (and their families) based on Article 39 of the EC Treaty. At the formal level, EU citizenship enhances pre-existing rights by expressly extending the right of free movement to persons "not seeking economic advantage or services." 121 To a large extent, however, this "decommodified"122 EU citizenship simply codifies accrued developments under Community law. Still, Article 18 of the EC Treaty provides a firm foundation for further expansion of this fundamental right under Community law. Thus, in the spirit of modernizing and extending the basic legal framework governing free movement of persons, the EU enacted a new directive in April 2004 that revamps the rights of Union citizens and their family members (including in some cases registered partners) to move and reside freely within the territory of the Member States. ${ }^{123}$

119. The formal legal content of EU citizenship comprises numerous elements that are spread throughout the treaties, along with related secondary Community legislation. The principal source for ascertaining the content of EU citizenship is Part Two of the EC Treaty, supra note 95, Articles 17-22, the provisions of which confer four types of rights on EU citizens.

120. "Every citizen of the Union shall have the right to move and reside freely within the territory of the Member States, subject to the limitations and conditions laid down in this Treaty and by the measures adopted to give it effect." Id. at Art. 18(1). This right is akin to a purported right under the Privileges and Immunities Clause of the U.S. Constitution to "enter any State of the Union, either for temporary sojourn or for the establishment of permanent residence therein." Edwards v. California, 314 U.S. 160, 183 (1941) (Jackson, J., concurring).

121. Everson, supra note 72 , at 89 .

122. Iyiola Solanke, The Decommodification of European Citizenship 2 (2005) (unpublished manuscript on file with author) (noting that the "'market" citizen whom the member states have slowly and in some cases unwillingly learnt to accept is being recast as a 'social' citizen").

123. European Parliament and Council Directive 2004/38 On the Right of Citizens of the Union and Their Family Members to Move and Reside Freely Within the Territory of the Member States, 2004 O.J. (L 158) 77. Member States must implement the provisions of this Directive, which has the potential to affect millions of lives, by April 20,2006. The Commission asserts that this Directive "marks a major step forward in terms of freedom of movement and residence" for all European citizens and their family members (broadly defined). Fourth Citizenship Report, supra note 107 , at 5 . First, this Directive revamps the legal framework in this field by codifying "in a single instrument the complex legislative corpus and the rich case-law on free movement and residence." $I d$. at 6 . It does not quite amount to a clean sweep, but replaces the bulk of former legislation in the field, and amends the few old measures that remain in place. Second, this new framework simplifies conditions and formalities, and will thus facilitate the exercise of the right of residence. Third, it creates a permanent right of residence in the host Member State after five years 
Second, EU citizenship confers "heavily circumscribed"124 political rights on EU citizens. In particular, EU citizens have the right to stand and to vote in European Parliament and municipal elections in their Member State of residence, even if they are not nationals of that state. ${ }^{125}$ A body of secondary law is slowly developing to put these measures into effect. ${ }^{126}$ Even at its current embryonic stage of development, this element of Union citizenship significantly expands the type of rights enjoyed by individuals within the EU's constitutional legal order, at least in most Member States. ${ }^{127}$ There is some pressure for further Europeanization in the field of electoral rights, insofar as EU citizens regularly express growing concern about the underdeveloped state of their rights to political participation. ${ }^{128}$

Third, Union citizenship creates new options for EU citizens who find themselves abroad and in need of diplomatic or consular help. In particular, EU nationals of one Member State can turn to the authorities of another Member State for help in cases involving death, illness, arrest, and other forms of distress, provided that their own Member State has no embassy or consulate in the third country where help is needed. ${ }^{129}$ This right does not provide an

of continued residence. Fourth, the Directive treats registered partners as family members in defined cases, and requires at the very least that Member States in other cases "facilitate entry and residence of partners with whom the Union citizen has a durable relationship." Id. at 6.

124. Everson, supra note 72, at 89; see also Jones, supra note 73, at 147-48 (arguing that the participatory rights "remain at the level of polity-maintenance and do not encroach far into areas of substantial interest to the majority of the population of the EU").

125. "Every citizen of the Union residing in a Member State of which he is not a national shall have the right to vote and to stand as a candidate at municipal elections in the Member State in which he resides, under the same conditions as nationals of that State." EC Treaty, supra note 95, Art. 19(1).

126. The Commission has reported the following developments in the field of electoral rights. First, common principles for conducting elections to the European Parliament came into force on April 1, 2004. Council Decision 2002/772 of 25 June 2002 and 23 September 2002, amending Act Concerning the Election of the Representatives of the European Parliament by Direct Universal Suffrage, 2002 O.J. (L 283) 1, amending 1976 Act [annexed to Decision 76/787/ECSC, EEC, Euratom of 20 September 1976, O.J. (L 278) 5]. Second, new rules have been adopted that establish a framework for financing European political parties from the Community budget. European Parliament and Council Regulation 2004/2003 on the Regulations Governing Political Parties at European Level and the Rules Regarding Their Funding, 2003 O.J. (L 297) 1. See generally Fourth Citizenship Report, supra note 107, at 8-9.

127. Some current Member States-including Sweden, Denmark, and the Netherlands"extended municipal voting rights to noncitizens" as early as the mid-1970s. CROUCHER, supra note 1, at 56. See generally Rainer Bauböck, Expansive Citizenship_-Voting beyond Territory and Membership, 38 PS: POLITICAL SCIENCE \& POLITICS 683 (Oct. 2005).

128. Some EU citizens perceive "a gap in electoral rights" that deprive them of the "right to participate in national or regional elections" when they exercise their personal freedom of movement. Fourth Citizenship Report, supra note 107, at 8-9 (reporting "[r]ecurrent petitions, parliamentary questions and public correspondence"). Among EU Member States, only Ireland and the United Kingdom "grant electoral rights at national or regional elections to nationals of other Member States residing in their territory." Id. at 9.

129. "Every citizen of the Union shall, in the territory of a third country in which the Member State of which he is a national is not represented, be entitled to protection by the diplomatic or consular authorities of any Member State, on the same conditions as the nationals of that State." EC Treaty, supra note 95 , art. $20(1)$. 
alternative to protection by the Member State whose national the EU citizen is, but merely a back-up for cases where that state is not in a position to help the citizen in need. In such circumstances, Union citizenship broadens the classic duty of states toward their own nationals under international law to include nationals of fellow Member States. Secondary legislation implementing this right became effective in May 2002, after a slow ratification process. ${ }^{130}$

The fourth element of citizenship in the narrow sense pertains to the relationship between the citizen and the institutions of the Union. In particular, Union citizenship introduced two non-judicial means of redress for citizens, ${ }^{131}$ one via the European Parliament ${ }^{132}$ and the other (in cases involving maladministration by Community institutions or bodies) via the Ombudsman. ${ }^{133}$ These rights are bolstered by a guarantee that EU citizens may correspond and be answered in any of the official languages with the EP, the Ombudsman, and other EU institutions and advisory bodies. ${ }^{134}$ However, the fact that neither of these rights of access is available solely to Union citizens diminishes their significance as markers for citizenship. ${ }^{135}$

\section{ii. Citizenship in the Broad Sense: Rights Based on Other Sources}

In terms of content, the last major component of EU citizenship is an array of rights ${ }^{136}$ whose sources are found outside Part Two of the EC Treaty. ${ }^{137}$ For

130. Council Decision 95/553 Regarding Protection for Citizens of the European Union by Diplomatic and Consular Representations, 1995 O.J. (L 314) 73. See generally Fourth Citizenship Report, supra note 107, at 9.

131. "Every citizen of the Union shall have the right to petition the European Parliament in accordance with Article 194. Every citizen of the Union may apply to the Ombudsman established in accordance with Article 195." EC Treaty, supra note 95, art. 21.

132. "Any citizen of the Union, and any natural or legal person residing or having its registered office in a Member State, shall have the right to address, individually or in association with other citizens or persons, a petition to the European Parliament on a matter which comes within the Community's fields of activity and which affects him, her or it directly." EC Treaty, supra note 95, art. 194. The European Parliament received 1283 petitions during its 2001-2002 term, of which 744 were admissible, and 1514 during its 2002-2003 term, of which 642 were admissible. Fourth Citizenship Report, supra note 107, at 9.

133. The Ombudsman is appointed by the European Parliament and is "empowered to receive complaints from any citizen of the Union or any natural or legal person residing or having its registered office in a Member State concerning instances of maladministration in the activities of the Community institutions or bodies, with the exception of the Court of Justice and the Court of First Instance acting in their judicial role." EC Treaty, supra note 95, art. 195(1). The Ombudsman has seen a steady rise in the number of complaints received in recent years. Fourth Citizenship Report, supra note 107 , at 9.

134. EC Treaty, supra note 95, art. 21. Reich, supra note 102, at 11-14, explores some of the more difficult questions of citizenship that arise in connection with the use of one's own (or a preferred) language when dealing with public authorities.

135. Moreover, the eroding margin of preference between citizens and resident aliens may help to explain declining rates of naturalization in some states. CROUCHER, supra note 1, at 55-58.

136. Thorough analysis of this important topic is beyond the scope of this article. A good starting point in the voluminous literature is de Búrca, who surveys the usages of the language of rights in Community law and provides an overview of the various contexts in which rights had arisen 
the most part, such rights are based either on other treaty provisions, jurisprudence of the European Court of Justice, or both. The Commission has proclaimed that the "most significant"138 among citizenship rights in this broader sense are those derived from Article 12 (ex 6) EC Treaty, which prohibits "any discrimination on grounds of nationality."139 Yet this right, together with the right of free movement noted above, has been a core principle of Community law since the beginning of European integration. As such, it is difficult to view it as an innovation attributable to the emergence of Union citizenship. ${ }^{140}$

Broader notions of individual rights extending beyond this traditional core $^{141}$ have emerged slowly and awkwardly under Community law. The ECJ opened the door to the development of individual rights as general principles of Community law, ${ }^{142}$ often at the behest of German litigants or courts. ${ }^{143}$ However, efforts to formalize rights in the treaties have encountered resistance along the way. This has been particularly true for two categories of rights: first, social rights, ${ }^{144}$ and second, civil and political liberties. ${ }^{145}$ Both these

by 1995. Gráinne de Búrca, The Language of Rights and European Integration, in SHAW \& MOORE, supra note 72 , at $29,29-54$.

137. "[M]uch of what makes EU citizenship worth having is scattered throughout the acquis rather than encapsulated in Articles 17-22." Warleigh, supra note 61, at 27.

138. Fourth Citizenship Report, supra note 107, at 4

139. EC Treaty, supra note 95, ant. 12. See generally Gareth Davies, 'Any Place I Hang My Hat?' or: Residence is the New Nationality, 11 EUR. L.J. 43 (2005).

140. The "rights of the market citizen, particularly that of free movement, have not merely been transferred to the Union citizen but continue to form the very core of that citizenship." Everson, supra note 72 , at 79 .

141. The continuing special role of these principles is acknowledged by their restatement in Part I of the EU Constitution, which provides:

(1) The free movement of persons ... shall be guaranteed within and by the Union, in accordance with the Constitution.

(2) Within the scope of the Constitution, and without prejudice to any of its specific provisions, any discrimination on grounds of nationality shall be prohibited.

Art. I-4, EU Constitution. The EU Constitution has not yet entered into effect.

142. Already in the 1970 s, the ECJ declared various "fundamental rights" to be part of the general principles of Community law. See, e.g., Case 11/70, Internationale Handelsgesellschaft v. Einfuhr- und Vorratsstelle für Getreide und Futtermittel 1970 E.C.R. 1125; Case 4/73, Nold v. Commission 1974 E.C.R. 491; Case 44/79, Hauer v. Land Rheinland-Pfalz 1979 E.C.R. 3727. These early cases focused on "economic, commercial, and property rights, such as the right to trade, the right to use land, and economic liberty." De Búrca, supra note 136, at 31 . The ECJ also recognized so-called "rights of the defense" early on, such as "the privilege against self-incrimination, the right to a hearing, freedom from search and seizure, confidentiality of information, and protection from excessive penalties." Id. at 32 .

143. See, e.g., de Búrca, supra note 136, at 39 (noting that the "challenge to the supremacy of Community law... came first from the German legal system, in which constitutionally recognized rights were allegedly infringed by Community measures"). For those challenges, see Decision of the Bundesverfassungsgericht [BVerfG] (Federal Constitutional Court) of May 29, 1976, 37 Entscheidungen des Bundesverfassungsgerichts [BVerfGE] (Decisions of the BverfG) 271 (F.R.G.); Decision of the BVerfG of Oct. 22, 1986, 73 BVerfGE 339 (F.R.G.); available at http://www.bverfg.de/entscheidungen (last visited Nov. 21, 2005).

144. Social rights are not primarily judicial creations in Community law, but have emerged through a fitful process involving agreements among the Member States themselves and secondary 
categories of human rights have gradually been incorporated, at least to some degree, into the EU's legal order. Yet not even the EU Charter of Fundamental Rights succeeded in fully incorporating such rights into the corpus of Community law. ${ }^{146}$ Absent a constitutional settlement to resolve these long-

legislation enacted at the European level in cases where the Member States have agreed to establish legislative bases for such measures in the EU's treaty framework. Willing Member States have articulated two charters of social rights, and tried (but largely failed) to incorporate them into the EU's treaty framework. The high-water mark achieved thus far is the Treaty of Amsterdam, supra note 95, which amended the TEU's Preamble to confirm the Member States' "attachment to fundamental social rights as defined in the European Social Charter signed at Turin on 18 October 1961 and in the 1989 Community Charter of the Fundamental Social Rights of Workers." This commitment is operationalized by Article 136 (ex 117) of the EC Treaty, supra note 95, which provides in this regard that the "Community and the Member States ... shall have as their objectives the promotion of employment, improved living and working conditions, ... proper social protection, dialogue between management and labour, the development of human resources with a view to lasting high employment and the combating of exclusion." However, Article 136 does not provide for full harmonization in this field, but merely calls for the implementation of "measures which take account of the diverse forms of national practices ... and the need to maintain the competitiveness of the Community economy." Art. 136, para. 2. The social policy fields in which the Community may act are spelled out more clearly in Article 137 (ex 118A), which embodies the strained compromise between Community and Member State competences in this contested field. Secondary legislation in the field of social policy has also been adopted at European level pursuant to a variety of other treaty provisions, including Article 141 (ex 119) relating to equal pay for male and female workers.

145. This category of rights, like social rights, has developed gradually in Community law, and not without controversy. One of the key challenges for the EU has been to work out the relationship between the Community legal order and the ECHR, supra note 89 , which all Member States have adopted, as well as with the European Court of Human Rights. See generally Joseph H.H. Weiler, Fundamental Rights and Fundamental Boundaries: On the Conflict of Standards and Values in the Protection of Human Rights in the European Legal Space, in WEILER, THE CONSTITUTION OF EUROPE, supra note 76, at 102 . Community institutions expressed their view early on that the ECHR framework should be viewed as part of the Community legal order. See Joint Declaration on Fundamental Rights, 1977 O.J. (C 103) 1. For its part, the ECJ has referred to the ECHR in numerous cases, though it has been careful to preserve its own role as sole interpreter of fundamental rights within the EU's legal order. More recently, explicit references to fundamental rights and even to the ECHR have been incorporated into the EU's own treaty framework. For example, the Preamble to the TEU, supra note 92, confirms the Member States' "attachment to the principles of liberty, democracy and respect for human rights and fundamental freedoms and the rule of law," while Article 6(1) (ex F) of the TEU asserts that the "Union is founded on the principles of liberty, democracy, respect for human rights and fundamental freedoms, and the rule of law, principles which are common to the Member States." The most explicit statement of the relationship can be found in Article 6(2) of the TEU, which states that "[t]he Union shall respect fundamental rights, as guaranteed by the European Convention for the Protection of Human Rights and Fundamental Freedoms signed in Rome on 4 November 1950 and as they result from the constitutional traditions common to the Member States, as general principles of Community law" (emphasis added). These general statements are not mirrored in the concrete policy areas delineated in Article 3 of the EC Treaty. However, the Treaty of Amsterdam did add a new provision empowering Community institutions to take concrete steps to expand non-discrimination beyond the traditional concern with nationality by taking "appropriate action to combat discrimination based on sex, racial or ethnic origin, religion or belief, disability, age, or sexual orientation." EC Treaty, supra note 95 , art. 13.

146. Charter of Fundamental Rights of the European Union, 2000 O.J. (C 364) 1. The charter was annexed to the Treaty of Nice but is not legally binding. See generally Erik Oddvar Eriksen, Why a Charter of Fundamental Human Rights in the EU?, 16 RATIO JURIS 352 (2003). See also Fourth Citizenship Report, supra note 107, at 9 (noting the "close link" and numerous overlaps 
standing complexities, the status and contours of rights in the EU, as well as the proper relationship between Union citizenship and human rights in the EU, ${ }^{147}$ remain vital arenas of contestation.

Linking human rights (that is, those based on sources other than Part Two of the EC Treaty) to the overarching concept of Union citizenship might open a new avenue for embedding such rights in Community law. Yet this tactic is not without risk. The more recent invention of EU citizenship, which claims to have "placed the individual at the heart" of the Union's activities, ${ }^{148}$ consolidates and bolsters the EU's commitment to rights, but does not fully encompass it. An institutional decision has been taken to gather the increasingly dense and coherent body of rights taking shape within the EU's legal order under the umbrella concept of citizenship, in order to fill out the contours of Union citizenship and render it more legitimate in the eyes of the affected persons. While it makes conceptual sense to link citizenship to rights in the broader sense, particularly given the central role of rights in Marshall's canonical definition of citizenship, doing so runs the risk of further complicating an already complex area of EU law. Moreover, any effort to squeeze human rights into the corset of citizenship risks stifling their development. These risks caution against subordinating rights to citizenship, at least until such time as the discourse or techniques of citizenship can contribute fruitfully to the development of rights jurisprudence in the EU.

\section{iii. Conclusions on Citizenship and Rights}

The relationship between rights and citizenship in the EU is likely to remain ambiguous for some time to come, not least in the wake of the obstacles encountered by the EU Constitution during the ratification process in 2005. Yet regardless of how the overarching ambiguities surrounding the relationship between rights and citizenship are ultimately resolved, the fact remains that citizenship and rights (in the narrow and broad senses identified above) are both experiencing a boom phase in the EU. Future research should attend to the evolving relationship between citizenship and rights, particularly to how developments in one arena affect developments in the other, and whether their developmental trajectories converge or diverge.

\section{c. Functional Continuity Between National and Union Citizenship}

The third dimension of continuity between national and EU citizenship

between Union citizenship and the Charter).

147. Weiler, Eros and Civilization, supra note 76, at 334, takes issue with the "conflation of citizenship with (human) rights," while O'Leary criticizes the EU for its "failure to recognize an explicit link between fundamental rights and the scope and operation of [Union] citizenship." Siofra O'Leary, The Relationship Between Community Citizenship and the Protection of Fundamental Rights in Community Law, 32 COMMON MARKET L.R. 519, 537 (1995).

148. Fourth Citizenship Report, supra note 107, at 9. 
comprises the function of citizenship. Both types of membership constitute a fundamental means of promoting democratic legitimacy, and hence allegiance to the institutions of governance. ${ }^{49}$ In practice, the EU's traditional "marketbased citizenship has proved insufficient as a means of generating support for, and loyalty to, the EU." 150 Whether Union citizenship can turn around the EU's legitimacy deficit and win the 'hearts and minds' of its citizens remains an open question. ${ }^{151}$ The success of citizenship as a means of generating collective identity must ultimately be measured by the extent to which it actually encourages "political engagement with the Union and its decision-making." 152 Viewed in this light, EU citizenship reduces in some measure to a chicken-andegg problem: What comes first, the (supra)nation or its (supra)national citizens? ${ }^{153}$

\section{d. Conclusions on Nationality and Citizenship in the EU}

The apparent continuity between national and Union citizenship is deceptive. On the one hand, EU Member States retain sovereignty to define who 'belongs to' them by drawing the "cultural, horizontal boundary between insiders and outsiders, that is between members and non-members of the nation." 154 Yet notwithstanding their formal authority, these states are

149. See de Búrca, supra note 136, at 40-41; Everson, supra note 72 , at $83-84,89$ (referring to the functional requirement of allegiance); Warleigh, supra note 61, at 21 (arguing that the EU had a "double rationale" for creating EU citizenship: first, "a utilitarian justification, centred on making a success of the single market," and second, "a more normative telos of helping reduce the notorious democratic deficit").

150. Bellamy \& Warleigh, supra note 32 , at 12 ("So far, Union citizenship has failed to provide the mechanism for a significant attachment between either the publics of the member states or the Union and the various national demoi.").

151. Warleigh has shown that the "take-up rates and the actual influence of those citizens and citizens' groups who rise to the [citizenship] challenge are often relatively low." Warleigh, supra note 61 , at 19 . The mechanisms available to the EU "appear weak ... compared with those of sovereignty and status evolved at national level," Everson, supra note 72, at 89, particularly insofar as the EU lacks the capacity to "bribe" its way into the "hearts of citizens through the provision of public welfare." Bellamy \& Warleigh, supra note 32, at 12.

152. Bellamy \& Warleigh, supra note 32 , at 12 . Those authors argue that the "EU has ... largely failed to capitalize on the opportunity to provide citizens with an alternative means of effecting political change," and that "for EU citizenship to be meaningful, it must be reinvented as an instrument of political engagement: a tool for the expression of opinions and the resolution of problems rather than simply a batch of entitlements." Id. at 12-13.

153. Another way to conceptualize this dilemma is in terms of building citizenship from the 'bottom-up' or from the 'top-down'. On the one hand, it is hard not to see parallels between Union citizenship and earlier top-down nation-building efforts, such as followed the French revolution. See, e.g., Franck, supra note 12, at 372-73 (discussing the creation of "a new [French] nation of shared political ideals, from the top down" through the efforts of a "new and much broader-based elite of officialdom, professionals, educators and intellectuals," who "deliberately... [spread] a national language, culture and identity"). In contrast, Wiener argues that "identities are never generated by the institutions of the state but have been created through practice." Wiener, Fragmented Citizenship, supra note 69, at 531 .

154. Preuß, supra note 13, at 23 (contrasting this cultural criterion of belonging with the "socio-economic, vertical, dimension of top and bottom, that is, of class cleavages"). 
increasingly subject to universalistic non-discrimination and equality norms that constrain them to make such decisions on the basis of individual rather than group characteristics. ${ }^{155}$ The autonomy of the Member States is further constrained by developments at EU level that erode their ability to define the rights of persons within their territory. ${ }^{156}$ Thus the continuities identified above, while substantial, appear to be of declining significance. Moreover, the continuities between national and Union citizenship do not negate the novelty of the latter, nor should they be allowed to blur the distinctions between the two. 157

Despite persistent "ambivalences and worries"158 about its meaning, EU citizenship clearly marks "a dramatic deviation from modern concepts of citizenship," 159 and offers the most vivid contemporary example of postnational ${ }^{160}$ membership. Four actual or potential points of departure from the Westphalian model of state-based citizenship have been identified in the preceding analysis. First, although Union citizenship is still derived from Member State nationality, there are numerous signs that this nexus is eroding de facto, as rights in the European legal space are increasingly uncoupled from nationality and citizenship. Second, the traditional Member State autonomy on matters of nationality faces a potential de jure threat, insofar as EU institutions appear poised to encroach on their prerogatives. Third, the creation of EU citizenship departs from the exclusivity inherent in Westphalian orthodoxy by

155. "[C]ollective and ascriptive modes of exclusion have been replaced by individualist modes of exclusion." Joppke, supra note 2, at 46. In Joppke's view, "nation-states . . . continue to exist but national particularisms can no longer be enforced through their membership policies... [despite] (almost) unfettered state sovereignty in matters of immigration and nationality law," id. at 44 , since "[l] iberal non-discrimination and human rights norms have put brakes on the particularistic nation-building possibilities of the state. Its membership policies may still be notionally 'nationbuilding', but only in the generic sense of forging non-ethnic, liberal-democratic collectivities that are not different here from elsewhere." Id. at 54. Moreover, as noted supra in note 111 , the ECJ keeps a watchful eye to ensure that the Member States have due regard for Community law when exercising their competence over nationality.

156. For example, Warleigh, supra note 61 , at 26 , observes that citizenship "clips the wings of the member governments" in terms of "national sovereignty over the welfare state, since member governments no longer have the right to decide on whether certain non-nationals are entitled to receive social security benefits."

157. That relationship is more ambiguous than meets the eye. Bellamy \& Warleigh, supra note 32 , at 8 , argue that the appearance of Union citizenship as "a discrete and detachable addition to, with no effect upon, national citizenship" is misleading, and insist rather that "Union citizenship reflects the fragmentation of national citizenship and not only supplements but replaces, interacts and occasionally competes and conflicts with it."

158. Bellamy \& Warleigh, supra note 32 , at 4.

159. Wiener, Fragmented Citizenship, supra note 69, at 530. See also Bellamy \& Warleigh, supra note 32, at 16 (Union citizenship "is more than symbolically important.").

160. I adopt Shaw's use of the term 'postnational' to describe EU citizenship, which is a "vital building block in the ongoing process of polity-formation within Europe." Shaw, supra note 22, at 294. This usage of the term is narrower than Soysal's, for whom the term refers to the situation in which "what were previously defined as national rights become entitlements legitimized on the basis of personhood." SOYSAL, supra note 76, at 3. 
reinstating the earlier European tradition of tolerating multiple loyalties. ${ }^{161}$ And fourth, the EU's sui generis nature is clearly revealed in the division of labor between the Union and its Member States, as well as in the nature of rights appurtenant to EU citizenship. Union citizenship "comprises rights and practices which distinguish the EU from any other international organization." 162 In particular, EU citizenship tacks the most basic rights accorded to individuals under international law (e.g., diplomatic protection) onto those accorded to individuals within a domestic constitutional order (e.g., democratic participation) and in a federally arranged political community.

EU citizenship constitutes a dramatic adaptation to an environment characterized by increasing intra-EU migration ('mobility') and decreasing Member State salience. Yet the dramatically changing nature of citizenship captures only part of larger debates about belonging in the EU. Indeed, questions about "the community of belonging and more specifically, about how to define borders of belonging" 163 are not limited to the realm of nationality or citizenship. Rather, other forms of social exclusion-such as those based on "ethnicity, race, and gender"-may be (or become) more salient than those based on nationality or citizenship. ${ }^{164}$ From this perspective, the development of rights in the EU legal order, including the evolving notion of equal opportunities for migrants discussed below in Part II.B.2., may be a more important arena for contests over belonging than the arena of citizenship itself.

\section{B. BELONGING IN: THE REGULATION OF MIGRATION}

\section{Overview}

Immigration policy is a field of increasingly circumscribed Member State sovereignty. Indeed, the EU's role in regard to immigration (as well as asylum $^{165}$ ) is much greater than it is in connection with citizenship, where the

161. "In historical terms, both nationalism and transnational regimes have long bid (sometimes competitively) for the adherence of persons. Indeed, in the past, persons have often had multiple or compound identities." Franck, supra note 12, at 359. Compare Richard Falk, The Decline of Citizenship in an Era of Globalization, 4 CITIZENSHIP STUDIES 5, 6 (2000) (distinguishing "thin" from "thick" affinities in this context).

162. Bellamy \& Warleigh, supra note 32 , at 16 . "EU citizenship is a novel mixture of nation-state-based and innovative supranational and transnational practices." Id. at 12.

163. Wiener, Fragmented Citizenship, supra note 69, at 529. Wiener notes that the question "[w] ho has a legitimate right to belong legally to [the EU] has become a much debated issue." Id. Particular debates over exclusion and inclusion have focused on the status of non-Member State nationals who reside within the EU, as well as on the other forms of social exclusion, such as race and gender. Id. at 551-52 n.5.

164. Id. at 530-31 ("[M]obilization around questions of ethnicity, race, and gender... represent a second challenge to the concept of citizenship, suggesting that the 'language of citizenship' is becoming outdated .... [T] and externally."). Wiener refers to this phenomenon as the "erosion of citizenship 'from below' by the trend to extend rights on bases other than nationality-based citizenship alone." Id. at 531 .

165. Due to space limitations, this article does not address the related field of refugee and asylum law, which has recently become an area of EU competence. The first phase of the Common 
Member States remain (to date) largely in control over questions of nationality. In contrast, Member States retain an essential, but clearly subsidiary role regarding the regulation of immigration. In this field, as in so many others, developments at the regional (EU) level are unprecedented, rapidly changing, and bear close watching. This section, like the previous one on citizenship, provides an overview of the regulation of immigration at EU level, in order to frame dramatic recent German legal reforms.

In concrete terms, immigration policy regulates "access to the territory of [a] state," as well as to "selected sectors of society, most notably the labour market." 166 Immigration policies thus regulate not only which migrants may enter a country, but also what such persons may do and how they must behave once they are there. In particular, some immigration laws address themselves not only to technical matters of entry, stay and deportation, but also proscribe the aim and, in some cases, the means of their integration into that state's social, economic, cultural, and even political structures. ${ }^{167}$ In this sense, migrants find themselves "at the cross-section of external and internal exclusion." 168 This nexus points to the close, and potentially continuous relationship between immigration and citizenship, where an emerging "non-discrimination norm regulates the legal transition from entry to residence to citizenship in the contemporary liberal state. $" 169$

From a historical perspective, both immigration and citizenship laws in liberal states have moved away from exclusion on the basis of ascriptive group distinctions, such as ethnicity and race. ${ }^{170}$ Instead, contemporary immigration

European Asylum System was adopted at EU level in 2004. Council Directive 2004/83/EC of 29 April 2004 on minimum standards for the qualification and status of third country nationals or stateless persons who otherwise need international protection and the content of the protection granted, 2004 O.J. (L 304) 12. For discussions of EU asylum law, see generally Gisbert Brinkmann, The Immigration and Asylum Agenda, 10 EUR. L. J. 182, 193-96 (2004); Sonia Boutillon, The Interpretation of Article I of the 1951 Convention Relating to the Status of Refugees by the European Union: Toward Harmonization, 18 GEO. IMMIGRATION L.J. 111 (2003); Rosemary Byme et al., Understanding Refugee Law in an Enlarged European Union, 15 EUR. J. INT'L L. 355 (2004).

166. Joppke, supra note 2, at 49.

167. See infra Part IV for a discussion of the integration requirements under EU, as well as under German law.

168. Joppke, supra note 2 , at 49 .

169. Joppke, supra note 2 , at 49 . As a consequence, liberal states facing anti-immigration public sentiment face limited options: they can close "all immigration," but cannot close "particular immigration" from one group or another. Id. at 50 (emphasis in original).

170. As noted in the discussion of citizenship, however, Germany continues to offer what Joppke describes as a "narrowly circumscribed" preferential treatment on the basis of ethnicity to some migrants. Id. at 49 (citation omitted). However, "[i]f one surveys the evolution of Western states' immigration policies since their first systematic elaboration at the beginning of the twentieth century, one notes their increased universalism, and the reduced scope of ascriptive group distinctions in them... [S] uch ascriptive group distinctions have notionally disappeared from immigration policies." Id. From these trends, Joppke draws the conclusion that the immigration policies of contemporary Western states "are no longer at the service of reproducing particular nationhood." Id. at 50. 
policies tend to be based on "individual criteria of skills and family ties."171 As a consequence of this trend, the term 'alien' is no longer a "national or ethnic category but [rather] a formal legal category" positioned at the opposite end of the spectrum from "citizen'. 172 The fact that "nationalist or xenophobic tendencies" in liberal states "are no longer institutionalized in [their] immigration policies (as used to be the case in the early twentieth century)" does not mean that they have been abolished; rather they have been relocated to the level of civil society. ${ }^{173}$ States that permit or even encourage inward migration "inevitably risk the ethnic and racial transformation of their societies," 174 along with the social tension that might accompany diversification of their populations.

This trend towards non-discrimination in the context of entry does not necessarily imply an overarching loss of state control over immigration. Liberal states, including the Member States of the EU in general and Germany in particular, retain and continue to exercise numerous levers of control over immigration. In addition to those techniques already noted - that is, policies defining the permitted bases for residence, imposing integration requirements on migrants, and setting criteria and procedures for deportation-states also exercise numeric control over the number of inward migrants to their territory.

\section{Regulating Migration in the EU}

Migration law, like Union citizenship, is a key component of the EU's Area of Freedom, Security and Justice ("AFSJ"), ${ }^{175}$ which in turn is one of the biggest growth areas in the EU's legal order. ${ }^{176}$ Growing EU competence in

171. Id. at 49 .

172. Id. ("The only legitimate group distinction left is that between 'citizens', who have a right to enter and cannot be expelled, and 'aliens' who have no such rights and are subject to a state's 'immigration' or 'foreigners' policies.").

173. Id. at $50-51$. It is a different (but important) empirical question whether liberal states apply such facially non-discriminatory criteria for entry, stay, and deportation in a manner that suggests de facto discrimination on the basis of ethnicity, nationality, or race.

174. Id. at 50 .

175. As already noted, the "policy orientations and priorities" needed to elaborate the AFSJ were first laid out in October 1999 in the Tampere Milestones. See supra note 106 and references cited therein. For an overview of the development of the AFSJ, see Helen E. Hartnell, EUstitia: Institutionalizing Justice in the European Union, 23 NORTHWESTERN J. INT'L L. \& BUS. 65 (2002).

176. See, e.g., Simon Green, Immigration, Asylum and Citizenship in Germany: The Impact of Unification and the Berlin Republic, 24 W. EUR. POL. 82, 99 (Oct. 2001) ("Undoubtedly, the main new paradigm is the increasing importance of the EU in asylum and immigration policy."). In substantive terms, immigration law and policy in the EU covers a wide range of issues, including labor migration, family reunification, political asylum, social integration, and the fight against illegal immigration (including human trafficking). See generally Terry Givens \& Adam Luedtke, The Politics of European Union Immigration Policy: Institutions, Salience, and Harmonization, 32 POL'Y STUD. J. 145 (2004); Matthias Knauff, Europäische Einwanderungspolitik: Grundlagen und aktuelle Entwicklungen [European Immigration Policy: Foundations and Current Developments], 1 ZEUS 11 (2004); Adam Luedtke, One Market, 25 States, 20 Million Outsiders?: European Union Immigration Policy (February 2005) (unpublished manuscript on file with the author); Jörg Monar, Justice and Home Affairs, 43 J. COMMON MKT. STUD. 131 (2005); Steve Peers, Key Legislative 
this field partly reflects the fact that it tends to be "the EU as a whole, rather than individual countries, [that] is emerging as an immigration destination." 177 Yet despite enormous changes in this recently-and increasinglyEuropeanized field, it remains one in which Member States continue to play an active role, as illustrated below by the recent German immigration reform.

The EU Member States committed themselves to "develop close cooperation on justice and home affairs" in the 1992 Maastricht Treaty of European Union ("TEU"). ${ }^{178}$ At the same time, they supplemented the Community's institutional architecture by erecting a common justice and home affairs policy ("JHA") as the intergovernmental Third Pillar of the newly established European Union. ${ }^{179}$ Most of the provisions formally incorporated into the EU's treaty structure in 1992 codified practices that had already emerged, particularly in the areas of asylum, immigration and police cooperation. The original treaties establishing the European Communities did not address any of the JHA matters that were formally brought within the scope of European integration by the TEU. However, both of these recent policy endeavors - the JHA and the AFSJ-are rooted in the free movement of persons, which is one of the freedoms ${ }^{180}$ at the core of the European integration project. $^{181}$

Developments on Migration in the European Union, 7 EUR. J. MIGRATION \& L. 87 (2005).

177. Green, supra note 176 , at 99 . "With the fall of the Iron Curtain ... migration to, through, and within Europe is the norm rather than the exception." Brinkmann, German Migrations, supra note 36, at 149. For a broader historical perspective on EU developments in the field of migration, see Claude Moraes MEP, The Politics of European Union Migration Policy (2003), at 1, available at http://www.europeananalysis.org.uk/research/moraes2.pdf (last visited Nov. 23, 2005) (arguing that "a complex but steady process of EU cooperation has taken place from the 1980' $\mathrm{s}$ ").

178. TEU, supra note 92 , art. 2.

179. Title VI (Provisions on Cooperation in the Fields of Justice and Home Affairs), TEU, supra note 92, art. K-K.9; see generally Peter Müller-Graff, The Legal Bases of the Third Pillar and its Position in the Framework of the European Union Treaty, 31 COMMON MKT. L. REV. 493 (1994). The Third Pillar crystallized into institutional structure those practices that had emerged for cooperation in the fields of justice and home affairs (JHA). Elspeth Guild, The Constitutional Consequences of Lawmaking in the Third Pillar of the European Union, in LAWMAKING IN THE EUROPEAN UNION 65, 65 (Paul Craig \& Carol Harlow eds., 1998). The nine "areas of common interest" identified by the TEU include: asylum policy; rules governing the crossing by persons of the external borders of the Member States; immigration policy and policy regarding nationals of third countries; conditions of residence by national of third countries (including family reunion and access to employment); combating unauthorized immigration, residence and work by nationals of third countries; and police cooperation for the purposes of preventing and combating terrorism, unlawful drug-trafficking, and other serious forms of international crime. TEU art. K.1 (before modification by the Treaty of Amsterdam).

180. EC Treaty, supra note 95, tit. III, art. 39-42 (ex 48-51). In the preamble to the preAmsterdam version of the TEU, supra note 92, the Member States "[reaffirmed] their objective to facilitate the free movement of persons, while ensuring the safety and security of their peoples, but including provisions on justice and home affairs in this Treaty." Id. at pmbl.

181. Freedom of movement of the individual is increasingly linked to the notion of "free movement of his or her fundamental rights." Elspeth Guild, Editorial, 10 EUR. L.J. 147, 149 (2004). In turn, this "security of rights for the individual"-irrespective of whether he or she is a citizen of the Union or of some third country-"is the essence of" the AFSJ. Id. See generally Norbert Reich, The Constitutional Relevance of Citizenship and Free Movement in an Enlarged Union, 11 EUR. L.J. 
The 1997 Treaty of Amsterdam substantially altered the preliminary JHA framework that had been established by the Treaty of Maastricht in 1992. ${ }^{182}$ Since the Treaty of Amsterdam entered into force on May 1, 1999, the TEU obliges the Member States "to maintain and develop the Union as an area of freedom, security and justice, in which the free movement of persons is assured in conjunction with appropriate measures with respect to external border controls, asylum, immigration and the prevention and combating of crime." 183 Also effective that date, a new Title IIIa on "Visas, Asylum, Immigration and other Policies related to Free Movement of Persons" was added to the EC Treaty. ${ }^{184}$ This change in the EC Treaty demonstrates one of the key innovations introduced by the Treaty of Amsterdam, which was to 'communitarize' some JHA issues by moving them from the intergovernmental Third Pillar to the supranational First Pillar. ${ }^{185}$ Indeed, since the Treaty of Amsterdam entered into force, the only issues remaining in the intergovernmental Third Pillar are police and judicial cooperation in criminal matters. ${ }^{186}$

The communitarization of migration law, while dramatic, did not effect a wholesale transfer of law and policy in this field to the EU. It did, however, substantially expand EU involvement in these volatile arenas. The Treaty of Amsterdam laid down a five-year timetable for adopting certain measures aimed at building the AFSJ. ${ }^{187}$ The Member State ministers of justice and home (interior) affairs met for the first time as an EU body in Tampere in October

675 (2005).

182. The Treaty of Amsterdam, supra note 95, amended both the EC Treaty, supra note 95, and the TEU, supra note 92. The Member States resolve "to facilitate the free movement of persons, while ensuring the safety and security of their peoples, by establishing an area of freedom, security and justice in accordance with the provisions of this Treaty." TEU pmbl. (emphasis added). In the consolidated version of the TEU, JHA provisions are found in art. 29-42.

183. TEU, supra note 92 , art. 2.

184. EC Treaty, supra note 95, art. 61-69 (as amended by the Treaty of Nice, supra note 95).

185. See generally Kay Hailbronner, European Immigration and Asylum under the Amsterdam Treaty, 35 COMMON MKT. L. REV. 1047 (1998); Pieter Jan Kuijper, The Evolution of the Third Pillar from Maastricht to the European Constitution: Institutional Aspects, 41 COMMON MKT. L. REV. 609 (2004). "In the sphere of the third pillar, the Member States are the actors; the institutional framework created by the Maastricht Treaty enables them to use Community institutions to facilitate their cooperation. The main actor in the sphere of the first pillar is the Community, acting on the basis of legislative powers conferred upon it by the Treaties." Hailbronner, supra at 1047. A further consequence of communitarization is that "[i]mmigration and asylum decisions by the Community ... will not only be binding for the EU Member States, but also be capable of having direct effect within the national legal orders, provided that they meet the general requirements ... developed by" the ECJ. Id. at 1048.

186. TEU, supra note 92 , tit. VI, art. $29-42$, as amended by the Treaty of Nice, supra note 95. The main innovation at Nice was the introduction of Eurojust. Kuijper, supra note 185, at 609 .

187. This timetable applied to many, but not all obligations created in the Treaty of Amsterdam, supra note 95. For present purposes, the only immigration measure required to be adopted during the five-year period was the adoption of measures on "illegal immigration and illegal residence, including repatriation of illegal residents" set forth in Article 63(3)(b) of the EC Treaty, supra note 95. 
1999, where they adopted an ambitious five-year plan $^{188}$ aimed at progressive adoption of the measures called for by the Treaty of Amsterdam. The target date for completing these "Tampere Milestones"-May 1, 2004-is the same date on which the EU was enlarged from fifteen to twenty-five members. ${ }^{189}$ In its final report ${ }^{190}$ at the end of this five-year term, the Commission poignantly noted that the "original ambition" regarding the AFSJ had been "limited by institutional constraints" as well as by the "lack of sufficient political consensus."191

Legal immigration is one of the main fields in which there was a marked gap between ambition and achievement during the first five-year program marked out by the 1999 Tampere Milestones, ${ }^{192}$ although a concerted push in 2003 and 2004 narrowed that gap considerably. ${ }^{193}$ Yet despite the tone of disappointment audible in the Commission's late scoreboards and in the AFSJ Report, ${ }^{194}$ the EU has taken numerous steps towards harmonization in the field

188. See supra note 106 and accompanying text (describing the Tampere Milestones). This program resulted in a virtual explosion of legislative activity, which was chronicled in the Commission's bi-annual 'scoreboard' reports. Each scoreboard appeared in the form of a Communication from the Commission to the Council and the European Parliament bearing the title Biannual Update of the Scoreboard to Review Progress on the Creation of an Area of "Freedom, Security and Justice" in the European Union. The scoreboards can be found in the following documents: COM (2000) 167 final; COM (2000) 782 final; COM (2001) 278 final; COM (2001) 628 final; COM (2002) 261 final; COM (2002) 738 final; COM (2003) 291 final; COM (2003) 812 final.

189. Peter J. VAN KRIEKEN, THE CONSOlidated ASylum and Migration ACQUis: THE EU DiRECTIVES IN AN EXPANDED EUROPE vii (2004); Joanne van Selm \& Eleni Tsolakis, The Enlargement of an "Area of Freedom, Security and Justice": Managing Migration in a European Union of 25 Members, 1 MIGRATION POLICY INSTITUTE POLICY BRIEF 4 (May 2004), available at http://www.migrationpolilcy.org/publ/eu enlargement.pdf (last visited Nov. 19, 2005).

190. In lieu of a final scoreboard report at the end of the five-year term, the Commission instead prepared the Communication from the Commission to the Council and the European Parliament, Area of Freedom, Security and Justice: Assessment of the Tampere Programme and Future Orientations, SEC (2004) 680 \& SEC (2004) 693, COM (2004) 401 final (June 2, 2004) [hereinafter AFSJ REPORT].

191. Id. at 5. In its report, the Commission anticipated further progress towards building the AFSJ in the wake of further liberalization of decision-making procedures. In this regard, it noted that some new procedures "automatically entered into force on 1 February 2003 and on 1 May 2004," and in addition that Article 67(2) of the EC Treaty, supra note 95, calls upon the Council "to take a decision with a view to providing for all or parts of the areas covered by Title IV to be governed by the co-decision procedure." Id. Declaration 5 concerning Article 67 of the EC Treaty, which was annexed to the Treaty of Nice, supra note 95 , contains a "precise political commitment to change over to the co-decision procedure immediately after 1 May 2004 for measures . . concerning the free movement of third-country nationals for a maximum three-month period and illegal immigration and residence, including repatriation." Id. at n.6. See Council Decision 2004/927, 2004 O.J. (L 396) 45 (providing for certain areas covered by Title IV of Part Three of the EC Treaty to be governed by the procedure laid down in Article 251 of that Treaty); see also Peers, supra note 176, at 87-89.

192. See, e.g., Scoreboard for the First Half of 2003, COM (2003) 291 final, at 4 ("[T]he degree of harmonisation is at risk of being reduced to the lowest common denominator at the expense of value added by common action at European level [in the field of legal immigration].").

193. VAN KRIEKFN, supra note 189, at vii, notes that "[the] Commission and Council more or less met the deadline."

194. AFSJ REPORT, supra note 190 , at 5 . The most significant measures adopted to date have been in the fields of expulsion, social security, family reunification, the status of long-term residents who are not EU citizens, entry and residence for the purpose of studies, vocational training 
of immigration law since 1999.

While Member States and EU institutions have renewed their commitment to pursue further harmonization in the field of immigration law and policy, as urged by the Commission's AFSJ Report, ${ }^{195}$ the field is characterized by a delicate balance between Member State and EU competence. This tension is already visible in the Commission's report. On the one hand, the AFSJ Report urges the need for a "realistic approach taking account of economic and demographic needs, to facilitate the legal admission of immigrants to the Union, in accordance with a coherent policy respecting the principle of fair treatment of third-country nationals." 196 On the other hand, however, the Commission explicitly acknowledges that the EU's ability to regulate this field remains constrained by the "right of Member States to set the actual numbers of thirdcountry nationals admitted to work in an employed or self-employed capacity." 197

The second five-year plan aimed at achieving the AFSJ was adopted by the Brussels European Council in November 2004. ${ }^{198}$ This so-called Hague

or voluntary service, and illegal migration. Despite this impressive list, the Commission's disappointment does not appear to be out of place. As van Selm has noted,

the policy documents on which the EU has managed to agree since 1992, when the EU first decided to cooperate on migration and asylum issues, have generally taken a minimalist approach. This has mean that few, if any, changes have been necessary in individual Member States to put new community laws into effect. Also, it often means a new EU law can allow some states to become more restrictive-although the EU law is intended only to set the minimum level of asylum or immigration practice permitted.

Joanne van Selm, The Hague Program Reflects New European Realities, MigRation POLICY INSTITUTE MIGRATION INFORMATION SOURCE (Jan. 1, 2005), at 1 , available at http://www.migrationinformation.org (last visited Nov. 19, 2005).

195. The AFSJ REPORT, supra note 190, at 16, calls for the elaboration of a "second European programme for the area of freedom, security and justice, with detailed priorities and a precise timetable" following the Tampere method.

196. AFSJ REPORT, supra note 190, at 9. The EU's economic and demographic needs, which were already articulated in the 1999 Tampere Milestones, pertain largely to labor shortages and to the "growing, if controversial, view that the EU as a whole will reed more immigration as its population ages." Moraes, supra note 177, at 8-9; see Tampere Milestones, supra note 106, ๆ III.20.

197. AFSJ REPORT, supra note 190, at 9. However, it asserts at the same time the need for "an overall framework including the respect of Community preference" as well as the "interests of countries of origin." Id. at 9-10. See generally Luedtke, supra note 176, noting that Germany was responsible for inserting the limitation to this effect in the EU Constitution.

198. Conclusions of the Presidency, Brussels European Council (Nov. 4-5, 2004), 14292/1/04 REV 1, If 15 (stating that the goal is to "enable the Union to build on [previous] achievements and effectively meet the new challenges it will face"). The Hague Programme Strengthening Freedom. Security and Justice in the European Union [hereinafter Hague Program] is attached to the Conclusions of the Presidency from that Brussels European Council (14292/1/04 REV 1) as Annex 1. The new Hague Program-which was initially referred to as "Tampere II"covers "all aspects of policies relating to the area of freedom, security and justice, including their external dimension, notably fundamental rights and citizenship, asylum and migration, border management, integration, the fight against terrorism and organised crime, justice and police cooperation, and civil law." Id. If 16. A European Strategy on Drugs 2005-2012 was added in December 2004. Conclusions of the Presidency, Brussels European Council (Dec. 16-17, 2004), 16238/1/04 REV 1, CONCL 4 (Feb. 1, 2005), ๆ 37. See generally Luedtke, supra note 176; van Selm, supra note 194, at 1 (noting that the Hague Program is "more of a "wish list"" than a "detailed 
Program introduces a new conceptual scheme organized around the "specific orientations" of freedom, security and justice, in lieu of the former organization along functional lines. ${ }^{199}$ Within this new framework, asylum, migration and border policy are ironically conceived of as policy measures that contribute toward "strengthening freedom" within the EU. 200 Among other objectives, the Hague Program aims to "improve the common capability of the Union and its Member States to . . . regulate migration flows."201

The Hague Program specifically addresses four aspects of migration. First, the European Council stressed the importance of legal migration and employment for "enhancing the knowledge-based economy in Europe" and for "advancing economic development." 202 In this context, the European Council called upon the Commission to formulate a plan for the regulation of legal migration, while simultaneously acknowledging that Member States remain competent to determine the number of labor migrants to be admitted to their territories. $^{203}$ The Commission quickly obliged by adopting a Green Paper on economic migration in January $2005,{ }^{204}$ which document aims to stimulate a

policy document").

199. Hague Program, supra note 198, Heading III, 14292/1/04 REV 1 ANNEX I, at 16. The Commission's scoreboards subdivided the heading "A Common EU Asylum and Migration Policy" as follows: partnership with countries of origin, a common European asylum system, fair treatment of third country nationals, and management of migration flows. See, e.g, Scoreboard for the First Half of 2003, COM (2003) 291 final, at 18-37. Separate headings existed inter alia for the Unionwide fight against crime, id. at 55-85, policies on internal and external borders (including visas and Schengen), $i d$. at 86-94, citizenship, id. at 95-96, and cooperation against drugs, $i d$. at 97-100. The scheme used in the Commission Scoreboards is based on that found in the 1999 Tampere Milestones, supra note 106. See generally van Selm, supra note 194, at 2 (noting the "subtle, but important ways in which [the Hague Program] diverges from the four themes included in the previous Tampere program").

200. Hague Program, supra note 198, If 1.2, 14292/1/04 REV 1 ANNEX I, at 16. In this regard, the European Council urges the "Council, Member States and the Commission to pursue coordinated, strong and effective working relations between those responsible for migration and asylum policies and those responsible for other policy fields relevant to these areas." Id. at 17. Moreover, it emphasizes the need for a "common analysis of migratory phenomena in all their aspects" and stresses the importance of collecting, providing, exchanging and efficiently using "upto-date information and data on all relevant migratory developments." Id. Two of the issues relevant to strengthening freedom are not discussed here, since they nominally fall outside the narrow scope of migration matters that I wish to consider. In particular, I do not examine the provisions of the Hague Program dealing with citizenship of the Union, $i d$. ๆ 1.1, at 16 , or the Common European Asylum System, $i d$. $\{1.3$, at 17-18.

201. Hague Program, supra note 198, 14292/1/04 REV I ANNEX I, ๆ I, at 12.

202. Hague Program, supra note 198, 14292/1/04 REV 1 ANNEX I, I 1.4, at 19. These goals were linked to "implementation of the Lisbon strategy," id., which program Commission President Barroso abandoned in February 2005.

203. Hague Program, supra note 198, 14292/1/04 REV I ANNEX I, I 1.4, at 19. In particular, such a plan should include "admission procedures capable of responding promptly to fluctuating demands for migrant labour in the labour market." Id.

204. Green Paper: On an EU Approach to Managing Economic Migration, COM (2004) 811 final (Jan. 11, 2005) [hereinafter Migration Green Paper]. The promptness of the Commission's response reflects its hitherto frustrated efforts to move the economic migration agenda forward. A directive proposed by the Commission in 2002 pursuant to the Tampere Milestones foundered for lack of political support and never became law. See Proposal for a Council Directive on the 
public debate among Member States, EU institutions, and "civil society, in particular the social partners" on this controversial topic. ${ }^{205}$

The second major aspect of migration addressed by the Hague Program is the integration of third-country nationals. In this context, the Hague Program largely reiterates and extends the objectives articulated in the 1999 Tampere Milestones, which called for a "common approach ... to ensure the integration into our societies of those third country nationals who are lawfully resident in the Union."206 Despite Tampere's call for a common approach, there is to date no harmonized definition of integration, and Member State policies and practices differ. After studying the issue, the Commission proposed a "holistic" 207 understanding of integration, which it conceptualizes "as a twoway process based on mutual rights and corresponding obligations of legally resident third country nationals and the host society which provides for full participation of the immigrant."208 The European Council has endorsed this "comprehensive" 209 and "incremental" 210 approach to integration, and thereby

Conditions of Entry and Residence of Third-Country Nationals for the Purpose of Paid Employment and Self-Employed Economic Activities, COM(2001) 386 final (July 11, 2001); see also COMMISSION COMMUNICATION ON IMMIGRATION, INTEGRATION AND EMPLOYMENT, supra note 109; Communication from the Commission to the Council, the European Parliament, the European Economic and Social Committee and the Committee of the Regions, First Annual Report on Migration and Integration, COM (2004) 508 final (July 16, 2004).

205. Migration Green Paper, supra note 204.

206. Tampere Milestones, supra note 106, I 4. In particular, under the heading "fair treatment of third country nationals," the Tampere Milestones called for a "more vigorous integration policy" which aimed at granting third country nationals "rights and obligations comparable to those of EU citizens." Id. ๆ III.18 (emphasis added). The Tampere European Council simultaneously called for enhancing "non-discrimination in economic, social and cultural life" and for developing "measures against racism and xenophobia." Id.

207. COMMISSION COMMUNICATION ON IMMIGRATION, INTEGRATION AND EMPLOYMENT, supra note $109, \uparrow 3.2$, at 18 ("[A] holistic approach takes into account not only the economic and social aspects of integration but also issues related to cultural and religious diversity, citizenship, participation and political rights."). In particular, a holistic approach "calls for comprehensive integration policies" in regard to integration into the labor market, education and language skills, housing and other urban issues, health and social services, the social and cultural environment, and nationality, civic citizenship and respect for diversity. Id. I 3.3, 3.3.1-3.3.6, at 19.

208. COMMISSION COMMUNICATION ON IMMIGRATION, INTEGRATION AND EMPLOYMENT, supra note 109, \ 3.1, at 17. In the Commission's view, such a holistic approach

implies on the one hand that it is the responsibility of the host society to ensure that the formal rights of immigrants are in place in such a way that the individual has the possibility of participating in economic, social, cultural and civil life and on the other, that immigrants respect the fundamental norms and values of the host society and participate actively in the integration process, without having to relinquish their own identity.

Id. \3.1, at 17-18. This Communication draws upon earlier Commission Communications. See COM (2000) 757 final and COM (2001) 387 final.

209. Hague Program, supra note 198, 14292/1/04 REV 1 ANNEX 1, ๆ 1.5, at 19 (noting the link between successful integration and social "[s]tability and cohesion" and expressing the need to "prevent the isolation of certain groups"). Moreover, a comprehensive approach is one that involves "stakeholders at the local, regional, national, and EU level." Id.

210. An incremental approach is based on the idea that rights and obligations develop and come into balance over time. COMMISSION COMMUNICATION ON IMMIGRATION, INTEGRATION AND EMPLOYMENT, supra note 109, I 3.1 , at 18 . "[T] hus, the longer a third country national resides 
taken a large step in the direction mapped out by the Commission. The Hague Program goes beyond Tampere's insistence upon "fair treatment of legally resident third-country nationals in the EU," insofar as it calls for "the creation of equal opportunities to participate fully in society." 211 To this end, and in view of the "need for greater coordination of national integration policies and EU initiatives in this field," the Hague Program expressly calls for establishing a "coherent European framework on integration." 12 This call was quickly answered by the JHA Council, which adopted "Common Basic Principles for Immigrant Integration Policy in the European Union" on November 19, 2004. ${ }^{213}$ These principles expressly preserve the Member States' leading role in regard to integration, which "must engage the local, regional, and national institutions, with which immigrants interact, in both the public and private realms." 214 In addition, the principles recognize that integration policies "will differ significantly from Member State to Member State." 15 This framework was readily visible in the two prior EU immigration directives, which deferred to Member States to determine what kind of integration requirements, if any, could be imposed on third country nationals. 216

Third, the Hague Program articulates the need to address in a more systematic way the external dimension of migration, which it views as essential, given the inherently international nature of this field. ${ }^{217}$

legally in a Member State, the more rights and obligations such a person should acquire." Id.

211. Hague Program, supra note 198, 14292/1/04 REV 1 ANNEX 1, 1 1.5, at 19. It bears mention in this context that the Hague Program insists that "[i]ntegration... includes, but goes beyond, anti-discrimination policy." Id. at 20.

212. Hague Program, supra note 198, 14292/1/04 REV I ANNEX I, I 1.5, at 20 (laying down minimum "common basic principles" intended to "form the foundation for future initiatives in the EU, relying on clear goals and means of evaluation").

213. Conclusions of the 2618th Council Meeting, Justice and Home Affairs (Brussels, Nov. 19, 2004), reported in Press Release C/04/321, $14615 / 04$ (Presse 321) (Nov. 19, 2004), at 11-13, plus Annex, id. at 13-18 (containing explanations that "are intended to give direction to the common basic principle") [hereinafter Common Basic Principles for Immigrant Integration]. This meeting of the JHA Council is occasionally referred to as the "Ministerial Conference on Integration." See, e.g., Conclusions of the Presidency, Brussels European Council (Dec. 16-17, 2004), 16238/1/04 REV 1, CONCL 4 (Feb. 1, 2005), ๆ 38 (welcoming the "establishment of common basic principles for immigrant integration policy of the Member States").

214. Common Basic Principles for Immigrant Integration, supra note 213, pmbl., ๆ 3 ("The development and implementation of integration policy is therefore the primary responsibility of individual Member States rather than of the Union as a whole.").

215. Common Basic Principles for Immigrant Integration, supra note 213, pmbl., | 6 ("They must be geared to the individual needs of the receiving society, reflecting each individual Member State's history and legal framework. They may also target diverse audiences, the mix of which varies between the Member States.").

216. See, e.g., Council Directive 2003/86/EC of 22 September 2003 on the right to family reunification, 2003 O.J. (L 251) 12, art. 7(2); Council Directive 2003/10/EC of 25 November 2003 concerning the status of third-country nationals who are long-term residents, 2004 O.J. (L 16) 44, art. 5(2). Both of these directives provide that Member States "may" require third country nationals to comply with integration conditions laid down by national law.

217. Hague Program, supra note 198, 14292/1/04 REV 1 ANNEX I, qा 1.6 \& 1.6.1, at 20. In particular, the Hague Program calls for forming partnerships with third countries, id. $\uparrow 1.6 .1$, at 2021 , and for development of a return and re-admission policy, id. $\uparrow 1.6 .4$, at 22-23. 
Fourth and last, the Hague Program addresses a range of issues pertaining to technical aspects of managing migration flows, ${ }^{218}$ which are particularly relevant to the fight against illegal immigration, cross-border crime and terrorism. In this context, the EU's primary objective is to "fully abolish internal borders while providing the maximum security and orderly passage at external borders." 219

Overall, the ambitious Hague Program still falls short of a "truly common European policy on immigration (and asylum).,"220 It preserves the current arrangement under which Member States first must agree on new measures within the Council, then subsequently implement the agreed measures into their domestic legal systems. This arrangement has resulted in relatively "low and slow" harmonization ${ }^{221}$ thus far in the highly contested migration arena. ${ }^{222}$

The Treaty of Amsterdam, subject to the later developments noted above, provides the relevant framework within which Member States can act, at least until such time as an EU Constitution or further treaty revisions enter into force. Three criteria constrain Member State sovereignty in this field. First, in terms of scope, EU institutions may adopt migration policy measures within three areas: conditions of entry and residence (including standards on procedures for the issue by Member States of long-term visas and residence permits); ${ }^{223}$ illegal immigration and illegal residence, ${ }^{224}$ and measures defining the rights and conditions under which nationals of third countries who are legally resident in a Member State may reside in other Member States. ${ }^{225}$ Second, the principle of subsidiarity is relevant in the migration field. ${ }^{226}$ The Treaty of Amsterdam

218. Hague Program, supra note 198, 14292/1/04 REV 1 ANNEX I, § 1.7, at 23-27.

219. Van Selm, supra note 194, at 4 .

220. Van Selm, supra note 194, at 5.

221. Under the Hague Program, "Member States can be expected to continue to seek legislation that is similar to their existing national laws," which are "perceived as much weaker than ones based on a 'clean sheet' developed at the EU level." Van Selm, supra note 194, at 5. Moreover, not even the move to qualified majority voting in this field is likely to "speed up this slow-moving process." Id. The decision to leave control over legal immigration and immigrant integration in Member States hands suggests that "the political will to truly have a European immigration policy is still lacking, in spite of rhetoric to the contrary." Id. at 5.

222. On the one hand, Member States face domestic political pressure to 'do something' about immigration. Seen from this perspective, Member State governments might well be reluctant to relinquish what control they still possess. Luedtke, supra note 176, at 4 (arguing that "one might not expect to see national governments willingly giving up what control they do have" over immigration, given the fact that they are often accused-and indeed, may be politically vulnerablefor "losing control" over immigration). On the other hand, this propensity is counterbalanced by fact that some Member States perceive transferring such issues to the supranational level as offering a measure of relief from domestic left-right contention. See Brinkmann, supra note 165, at 199 (suggesting that some countries perceive Community legislation on immigration as a way to shortcut domestic political contestation). reunion).

223. EC Treaty, supra note 95, art. 63(3)(a) (including those for the purpose of family

224. EC Treaty, supra note 95, art. 63(3)(b) (including repatriation of illegal residents).

225. EC Treaty, supra note 95 , art. 63(4).

226. Hailbronner, supra note 185 , at 1051. 
specifies that Member States remain competent to act in regard to these issues, and thus that EU competence is shared rather than exclusive in regard to these issues. ${ }^{227}$ Germany, which is particularly protective of its prerogatives in this field, submitted a letter to the President of the Council setting forth its interpretation of Article $63 .^{228}$ And finally, Member State sovereignty is expressly preserved "with regard to the maintenance of law and order and the safeguarding of internal security." 229

\section{CONCLUSION}

Even without its own Constitution and in the face of severely circumscribed powers regarding citizenship and migration, EU regional governance of these traditional state concerns has taken enormous strides in recent years. Yet despite increasing activity at the EU level regarding both issues, crucial questions of belonging remain in Member State hands. In regard to citizenship, the crucial question of inclusion or exclusion is largely tied up with the issue of nationality, which thus far remains a Member State prerogative. In connection with migration, the EU has taken minimal steps towards a common approach to the question of integration, but defers to the Member States to do what they deem necessary to make diversity work. Belonging thus remains largely a local issue, except where Member States tread upon rights defined by public international or EU law.

\section{III.}

\section{Reforming German LAW ANd Practice}

Two major legal enactments have transformed the German landscape in recent years: first, the overhaul of the Citizenship Act (Staatsangehörigkeitsgesetz), ${ }^{230}$ which entered into force on January 1, 2000, and second, the

227. EC Treaty, supra note 95, art. 63. National provisions must, however, be "compatible with [the EC Treaty] and with international agreements," $i d$., because Member States "did not intend to give up any national control on immigration." Hailbronner, supra note 185, at 1050.

228. Hailbronner, supra note 185, at 1051-52.

229. Hailbronner, supra note 185 at 1052 , rightly observes that this provision is ambiguous. Although immigration law "is traditionally considered as being part of the national public order," it does not follow that Article 64 means "that Member States keep a primary responsibility" in regard to these issues. Id. Rather, he suggests that Article 64 must be interpreted as referring "to the exercise of police power rather than to the formulation of an immigration policy and the legal conditions under which . . . third-country nationals will be permitted to enter Union territory." $I d$. at 1053.

230. The current Staatsangehörigkeitsgesetz (StAG) [hereinafter Citizenship Act] is an amended and consolidated text based on the Reichs- und Staatsangehörigkeitsgesetz (RuStAG), RGBI. I 583 (July 22, 1913) [hereinafter 1913 Citizenship Act], as amended, inter alia by the Staatsangehörigkeitsreformgesetz, BGBI I 1618 (July 15, 1999) [hereinafter Citizenship Reform Act]. Among other changes, the Citizenship Reform Act, which entered into effect on January l, 2000, retitled the 1913 Citizenship Act by dropping the Imperial reference from its title. Subsequent references to the "Citizenship Act" refer to its current consolidated version, including amendments 
omnibus Immigration Act (Zuwanderungsgesetz), ${ }^{231}$ which entered into force on January 1, 2005. The Citizenship Act represents an exercise of legislative sovereignty to determine which individuals relong to the German state. In this context, Germany's regulatory power is barely constrained by public international or EU law. In contrast, the Immigration Act is of a more hybrid nature, since its broad scope encompasses some issues that fall within the exclusive German domain, along with others regarding which Germany shares competence with the institutions of the EU. The Immigration Act thus includes a number of measures that are affected by, and in some cases already regulated by EU law. Indeed, some provisions of the new Immigration Act implement EU rules that are binding on Germany. Regardless of their implications for German legal sovereignty, both new Acts render Germany a more inclusive state, at least on the books.

\section{A. NATIONALITY AND CITIZENSHIP}

After reunification, Germany extensively revised its 1913 Citizenship Act. ${ }^{232}$ The new Citizenship $\mathrm{Act}^{233}$ has important implications, both in light of Germany's own past and with regard to the future prospects for postnational citizenship. The new Citizenship Act not only illustrates the government's "new pragmatism" in the face of demographic changes and labor-market imperatives, but also points towards a possible "transformation" of nationhood in

made subsequent to the date of the Citizenship Reform Act. There is considerable disagreement over the proper translation of Staatsangehörigkeit. I use the term 'citizenship' in this article, despite the fact that I consider 'nationality' to be the more accurate translation of this German term. Staatsangehörigkeit literally invokes the notion of belonging to the State, and may be contrasted with Staatsbürgerschafi, which term was explicitly coined by German authors such as Wieland and Kant to render the French term citoyen. Preuß, supra note 13, at 22-23. I consider Staatsbürgerschaft to be the better counterpart to the English term 'citizenship'. Indeed, Austria uses the term Staatsbürgerschaft in its law regulating nationality/citizenship, in lieu of Staatsangehörigkeit. However, usage by scholars is inconsistent. Compare Ludvig, supra note 61 and PreuB, supra note 13, with Minkenberg, supra note 34. I opt to use the term 'citizenship' here, in part because it is the term that the German government itself uses in English translations, but also because it is more consistent with the aim of the recent legal reform, which is to drive a wedge between citizenship and nationhood. See generally Joppke, supra note 2, at 54 .

231. Gesetz zur Steuerung und Begrenzung der Zuwanderung und zur Regelung des Aufenthaltes und der Integration von Unionsbürgern und Ausländern ("Zuwanderungsgesetz") [Law to Manage and Limit Immigration and to Regulate the Residence and Integration of Union Citizens and Foreigners], BGBI I 1950 (July 30, 2004) [hereinafter Immigration Act]. Most provisions of the new Immigration Act entered into effect on January 1, 2005.

232. Citizenship Reform Act, supra note 230. For historical analyses of the development of German citizenship law prior to the foundation of the Federal Republic in 1949, see GOSEWINKEL, supra note 13; NATHANS, supra note 34.

233. Citizenship Act, supra note 230. For a detailed analysis of key provisions, see Holger Hoffmann, The Reform of the Law on Citizenship in Germany: Political Aims, Legal Concepts and Provisional Results, 6 EUR. J. MigraTION \& L. 195 (2004). For an analysis of the political debates behind the new Citizenship Act, supra note 230, see Green, supra note 176; Randall Hansen \& Jobst Koehler, Issue definition, political discourse and the politics of nationality reform in France and Germany, 44 EUR. J. POL. RESEARCH 623 (2005); Minkenberg, supra note 34, at 220-25. 
Germany. ${ }^{234}$ While too early to predict such dramatic consequences with any degree of confidence, it is already apparent that the new law is having a major impact on the persons affected, for good or ill.

Germany is typically viewed as exemplifying the primordialist or organicist view that belonging presupposes ethno-cultural homogeneity. ${ }^{235}$ The new Citizenship Act has taken a first step away from "a model of ethno-cultural exclusion towards a model of multicultural inclusion."236 To be sure, the Citizenship Act is just the first of what are likely to be many steps in the years ahead, but it is an important one nonetheless. ${ }^{237}$ Brief conceptual and historical frames are provided to contextualize the ensuing discussion of the key changes and implications of Germany's new Citizenship Act.

In conceptual terms, one must begin by qualifying the common characterization of Germany as a practitioner of ethno-cultural exclusion. It is more accurate to recognize that Germany, like many other countries, recognizes a distinction between the particularistic notion of nationality and the more universalistic notion of citizenship. These notions emerged separately in German history, but later became entangled, and even fused, during the Nazi era and thereafter. ${ }^{238}$ However, post-war developments in general, and the new Citizenship Act in particular, show an incremental but nonetheless salutary tendency to decouple these two notions again. The developments surveyed below provide thus provide modest support for the hopeful claim that "the tradition of nationhood is not condemned to remain constant."239

In historical terms, the ethnification of German nationhood and citizenship

234. Stankiewicz, Changing Politics, supra note 46 , at 2 . That author considers Germany's "developing republican self-conception," but also discusses at length some of the problems that have arisen in that regard. Id. at 15-16, 27. See also Andrea Klimt, The Myth of Heimkehrillusion, 20 GERMAN POL. \& SOC'Y 115 (2002) (discussing the myth that foreign guest workers were temporary residents in Germany).

235. See, e.g., BRUBAKER, supra note 13; KASTORYANO, supra note 42, at 121 ("Germany ... is considered 'exclusivist' because of the significance accorded to criteria of membership based on ancestry .... [T] he German nation is defined as a cultural and ethnic unity based on common descent as a sign of belonging."). In contrast, some contemporary historians argue that "ethnicity was... not the only factor that determined whether a foreigner might become a German citizen. Decisions ... often reflected considerations of interest and utility that were distinct from the pursuit of ethnic homogeneity." NATHANS, supra note 34, at 1 . In his path-breaking analysis of German citizenship between 1815 and 1949, Gosewinkel emphasizes the importance of religious confession, military service, and gender for explaining German citizenship policy prior to the Nazi takeover. GOSEWINKEL, supra note 13. See also NATHANS, supra note 34, at 1-2 (arguing that economic utility, military recruitment, and relations with neighboring states were important explanatory factors).

236. Stankiewicz, Changing Politics, supra note 46 , at 3.

237. RENNER, supra note 39 , provides a detailed analysis of the current state of the Citizenship Act, supra note 230, including amendments since that law entered into effect on January 1,2000 .

238. The "extreme nature of [German] ethnic preferences ... does not apply only to the Nazi period." NATHANS, supra note 34 , at 1. Rather, "[f]rom the 1880 s to the 1980 s German naturalization policies assumed ethnically exclusive forms that can best be described as anxious and even obsessive." Id.

239. Stankiewicz, Changing Politics, supra note 46 , at 5 . 
resulted from a long process characterized by complexity and contingency. The concept of German nationhood that emerged in the context of the old Empire, and later became enmeshed with the formation of a German nation-state in 1871 , was a cultural one. ${ }^{240}$ Nationalist forces ${ }^{241}$ seeking an ethnically homogeneous German nation-state in the nineteenth century mobilized this cultural and linguistic ${ }^{242}$ notion of nationhood for their own purposes. Those nationalist forces were countered in the nineteenth century-and again after 1949-by proponents of a universalistic notion of citizenship that reflected the yearning "to live under the representative government of a single polity" and aimed to realize "the ideals of the French Revolution." 243 During the nineteenth century struggle against authoritarian rule, the "German liberation movement" regarded as "mutually reinforcing" the goals of national unification and constitutionalism. ${ }^{244}$ The ensuing "ethnification of German nationhood and

240. This historical overview relies heavily on Preuß, supra note 13. The original concept of "German Nation" had a different meaning from the modern concept that links nation to statehood and peoplehood. Rather, in the context of the medieval Holy Roman Empire of the German Nation, the original concept of nation "was embodied by the Imperial Estates" who ruled the old Empire. Id. at 24. Thus, unlike in France, England and Spain, where the idea of the nation became "associated with the monarchy and its emerging ius territoriale," the German concept of nation was prepolitical, and was viewed as the alternative to a bounded nation-state. Id. at 24-25.

The Germans lived in a plurality of territories and were ruled by a plurality of princes, while the single king who existed, the Emperor, had no immediate power over them. Moreover, none of the sovereign princes, including the hegemonic Prussian king, wished to establish a German nation-state. Thus, in eighteenth-century Germany the idea of a German nation emigrated into the sphere of culture.

Id. at 25 .

241. Preuß, supra note 13, at 28 . The nineteenth century proponents of particularism were "xenophobic and anti-Semitic" and "oscillated between ... ethno-cultural and . . . biological racist" definitions of "'Germandom' (Deutschtum)." Id. The Nazis "realized the goals of the nationalist movement" by providing a "racist definition of Germanness" in the "Greater German Empire" (Großdeutsches Reich) in 1933. Id.

242. Preuß, supra note 13, argues that the terms 'deutsch' and 'deutsches Volk' were originally used to designate "a linguistic community" and were not limited to the "neutral designation of a particular collectivity in a delineated territory." Id. at 26 . It was the latter "particularistic notion... which... anticipated important elements of the right-totalitarian movements of the twentieth century." $I d$. at 28 . With regard to the notion of linguistic community, however, Franck argues that

to the historically trained eye, this linguistic affinity is not a natural given. It has evolved through a synthesis of persons whose tribal origins and language may have been Visigoth, Prussian, Rhenish, Alsatian, Westphalian, Hannoverian, Saxon, Bohemian, Frisian, Sorb, Bavarian, Tyrolean, Celt, Slavic or Danish. These languages, to the extent they have survived, even today show differences from one another. German, like almost every other living language, is to a degree synthetic. Germany, moreover, is only in a mythic sense the manifestation of an etemal genetic or cultural unity.

Franck, supra note 12 , at 366.

243. Preuß, supra note 13 , at $27-28$.

244. Preuß, supra note 13 , at 27 ("[T]hey were convinced that Germans could achieve political freedom in a constitutional state only through being united in one single nation-state. As we know, this belief proved to be over-optimistic."). In other words, Germany tried to achieve in one step what France had achieved in "two consecutive and protracted steps, and with great difficulties, suffering and violent struggles." Id. 
consequently of German citizenship" resulted not from some innate characteristic of the German people, but rather from the concrete political circumstances surrounding state-formation in $1871 .^{245}$ Indeed, one leading scholar finds the "definition of nationhood in ethnic terms" and ensuing "distortion of the concept of nation... surprising," since "geographical, religious and socio-economic fragmentation" were "constant in German society ... ever since the Middle Ages." 246 In the alternative, it may have been precisely this experience of fragmentation that produced a "longing for social homogenization.,"247

Whatever constellation of factors generated the assumptions about membership that prevailed in the latter part of the nineteeth century, those assumptions were crystallized in the 1913 Citizenship $\mathrm{Act}^{248}$ enacted during the Wilhelmine era. That law remained in effect through the Weimar Republic, the Nazi reign of terror, and the Cold War division of Germany, though it was amended numerous times. The 1913 Citizenship Act applied the principle of $j u s$ sanguinus ${ }^{249}$ - or the principle of descent-to determine who belonged to Germany. ${ }^{250}$ While some view this legal rule as proof of German racism, it

245. Preuß, supra note 13 , at 33 , argues that the top-down nature of state formation was "probably ... the main cause" of ethnification. In particular, he argues that the "congenital defect of the Empire, namely its establishment from above ... without the participation of significant parts of the population" produced a "latent tendency towards aggressiveness, scapegoating and the need for identified enemies." Id.

246. Preuß, supra note 13 , at 34 . This outcome is also surprising, because "Prussia was the hegemonic power in the Empire and had a record of having a universalist state ethos." Id. Compare NATHANS, supra note 34, at 1 ("It would not have been hard to predict in the mid-nineteenth century that if a German nation-state were founded it would attempt to promote a feeling of ethnic solidarity among its inhabitants," given that "German national feeling did stress the bonds created by a common ethnicity and culture.").

247. Preuß, supra note 13, at 34 ("[T] splintering created a more or less conscious longing for social homogenization among large segments of the German population. This desire entailed the suppression of the tradition of openness in German society and gave way to the high degree of authoritarian rule characteristic of both the Wilhelmine Empire and the ... Third Reich.").

248. The 1913 Citizenship Act, supra note 230, was in turn, a revision of the 1870 Citizenship Act (Gesetz über die Erwerbung und den Verlust der Bundes- und Staatsangehörigkeit), RGBl I 355, which had "by and large standardized the particularistic rules of the member states." Preuß, supra note 13, at 33. It may be a telling parallel to contemporary European conditions that the German Empire founded in 1871 "rendered national membership of the Empire .. . dependent on the possession of nationality in one of its member states." $I d$. at 32 . Thus, prior to 1871 , there was no such thing as German 'nationality' but rather only individual membership in one of the 40 German states, pursuant to each state's rules on Landesangehörigkeit, which was the conceptual predecessor of Staatsangehörigkeit. Id. at 31 . One author has argued that unlike Imperial Germany, "there is no equivalent of an intimidating Prussian state that can dictate policy changes" in the EU. Tobias Brinkmann, Book Review, 22 GERMAN POL. \& SOC'Y 65, 68 (Winter 2004).

249. Jus sanguinus implies that "every person born to non-citizen parents will remain a foreigner unless he or she naturalises." Ludvig, supra note 61, at 502. Seen in historical context, the emergence of jus sanguinus represented a progressive break with feudal traditions that treated the individual as "a mere appurtenance of the soil." Preuß, supra note 13, at 31. "The defeat of the estatist orders by the state required the emancipation of the individual from several obligations to feudal lords, and the establishment of a singly and exclusive duty to obey the unifying ruler." $I d$.

250. Nazi elements of the 1913 Citizenship Act, supra note 230, were eliminated after 
bears mention that although the jus sanguinus principle "[can] be used as an instrument of ethnification," it does "not necessarily entail an ethnic definition of belonging." 251 Indeed, even before the new Citizenship Act entered into effect in 2000 , the principle of jus sanguinus meant that one "became a German citizen at birth simply by being born to a German parent, irrespective of the 'ethnicity' of the citizen parent."252 Yet such arguments about the ethnic neutrality of jus sanguinus, while technically correct, beg the question of how one becomes a German parent in the first place. Moreover, where there is a large foreign population, as in Germany since the Second World War, the jus sanguinus principle "constantly reproduces 'new-born' foreigners" in practice, since it denies citizenship to children born on German soil to foreign parents. ${ }^{253}$ Such a regime ultimately denies equality, in particular to second- and thirdgeneration foreigners who have no opportunity to naturalize in the country of their birth. ${ }^{254}$ Another "systemic weakness of pure jus sanguinus is that citizenship with some of its related rights can be transmitted over generations to persons residing abroad, without any substantial connections to the polity, whereas non-citizens remain non-citizens over generations, despite continuous residence and membership in a society." 255

Group selectivity ${ }^{256}$ did (and does continue to) exist in Germany, but it cannot be attributed solely to the principle of jus sanguinus. Rather, to the extent Germany did practice group-based exclusion, it resulted not from "the citizenship attribution via jus sanguinus" per se, but rather to a large extent from "the administrative implementation of naturalization (which in the inter-war period had preferred German-origin applicants from Russia and excluded eastern Jews)."257 Moreover, for those determined enough to apply, the process of naturalization was time-consuming, costly, and potentially bewildering.

The new German Citizenship Act significantly alters the conditions for acquiring, as well as for losing German citizenship. It does not wholly abandon

World War II. Stankiewicz, supra note 46, at 20. For an analysis of the Nuremburg Laws of 1935 , see GOSEWINKEL, supra note 13, at 383-93.

251. Preuß, supra note 13 , at 33 . Joppke, supra note 2 , at $52-53$, similarly observes that $j u s$ sanguinus "does not as such imply group selectivity," and thus that the "stereotype that ethnic citizenship is "racist' . . does not correspond to legal reality."

252. Joppke \& Morawska, supra note 3, at 53 ("German citizenship law had never been based on a legal definition of German ethnicity.").

253. Ludvig, supra note 61, at 499 .

254. Haas, Roever \& Schmidt, supra note 2, at 166.

255. Ludvig, supra note 61 , at 504 . The Citizenship Act, supra note 230 , addresses this problem by providing a new rule that cuts off the operation of jus sanguimus under certain circumstances in regard to the children of German citizens who are born and also reside abroad. RENNER, supra note 39, para. 1.5, at 12 (Generationenschnitt).

256. For the contrast between group and individual selectivity, see Joppke, supra note 2.

257. Joppke, supra note 2, at 53 (citing GoSEWINKEL, supra note 13, ch. 7, at 328-68). Under the 1913 Citizenship Act, supra note 230 , "there had always been the possibility to acquire German citizenship through naturalizing," though it was difficult to do so. Id. Still, this possibility implies that "'blood" in the principle of 'jus sanguinus' was formal and instrumental, not substantive." Id. 
jus sanguinis in favor of the jus soli principle, which grants citizenship according to principle of territoriality. ${ }^{258}$ However, the Citizenship Act does mitigate the "ethnic underpinnings of the state" 259 by rendering German citizenship "less exclusive and more accessible to the outside" 260 in a number of important respects. First, at the symbolic level, the changes mark a clear departure from the government's long-standing position that Germany "is not a country of immigration."261 Second, and of greater practical import, Germany has joined most of its European neighbors by introducing the jus soli principle in certain cases. ${ }^{262}$ And third, the new Citizenship Act continues the trend started in the 1970s to simplify procedures, curb administrative discretion, and lower costs, in the hope of encouraging more foreigners to naturalize. ${ }^{263}$

Under the jus soli provisions of the new Citizenship Act, a child born in Germany to non-German parents automatically becomes a German citizen, provided that the parents meet certain criteria, including legal residence in Germany for a period of eight years. ${ }^{264}$ Citizenship is also available as a matter of right to other persons through naturalization, if the applicant has lawfully resided in Germany during the eight years preceding the application and satisfies

258. Under the jus soli principle, "anyone, whatever their ethnic, racial, or national origins, will be granted automatic citizenship at birth (or optionally at a later stage)." Joppke, supra note 2, at 53. Some scholars argue that "territorial citizenship [that is, jus soli] has become the favoured form of citizenship in international law." Id. (citing Diane Orentlicher, Citizenship and National Identity, in INTERNATIONAL LAW AND ETHNIC CONFLICT (David Wippmann ed., 1998)).

259. Dieckhoff, supra note 14 , at 14 n.28.

260. Joppke, supra note 2 , at 53 .

261. "[S]ince 1977 successive German govermments have proclaimed that, contrary to the facts, Germany was not an immigration country." Minkenberg, supra note 34 , at 220 . This oftquoted statement comes from a 1977 report prepared by a joint commission of the federal and state governments. "The Federal Republic of Germany is not a country of immigration. West Germany is a country in which foreigners reside for varying lengths of time before they decide on their own accord to return to their home country." Vorschläge der Bund-Länder-Kommission zur Fortentwicklung einer umfassended Konzeption der Ausländerbeschäftigungspolitik (Feb. 1977), quoted in JOPPKE, supra note 2, at 287 (citing PETER KATZENSTEIN, POLICY AND POLITICS IN WEST GERMANY 239 (1987)).

262. This change 'marks Germany's long-overdue 'catching up' with its Western European neighbours, that is, the modernisation of its politics of citizenship by combining a residence-based nationality code (ius soli) in addition to the origin-based current code (ius sanguinus) with a wellregulated immigration policy." Minkenberg, supra note 34, at 219. However, Minkenberg disputes that the recent changes amount to "full 'catching up' with the policies of other Western countries" or, for that matter, that they constitute "an adequate response to the country's long-term needs for immigrants to maintain the viability of its labour markets and its social insurance system." $I d$. at 220 .

263. See generally Hoffmann, supra note 233, at 195-202 (noting various procedural changes, including changes in the types and degree of discretion), and at 202 (noting the newly fixed fees of 255 Euros per adult and 51 Euros per child). Prior to 2000, even the fee for naturalization was subject to administrative discretion. Id.

264. These conditions are spelled out in Article 4(3) of the Citizenship Act, supra note 230. See generally Hoffmann, supra note 233, at 199-200; RENNER, supra note 39, para. 2.3, at 24-28 (Geburt im Inland). In such cases, the child born in Germany must, between age 18 and 23, either elect to retain German citizenship, or risk automatically losing it on his or her 23rd birthday, in accordance with the provisions of Article 29 of the Citizenship Act. 
all other statutory criteria. ${ }^{265}$ Naturalization may also available in other cases on a discretionary basis. ${ }^{266}$ The new Citizenship Act does not abandon the presumption against dual nationality, ${ }^{267}$ but merely tolerates it during the minority of children born in Germany to foreign parents. ${ }^{268}$

The limited introduction of $j u s$ soli has not obliterated the legal distinction between foreigners (Ausländer) and resettlers (Aussiedler). ${ }^{269}$ Inclusive group selectivity continues to exist in the form of "automatic citizenship ... for ethnic Germans."270 Thus, some potential immigrants remain entitled to German

265. The Citizenship Act formally consolidates the right to citizenship by individuals on the basis of long-term residency, provided that all statutory criteria are satisfied. These requirements are spelled out in Article 10(1) of the Citizenship Act, supra note 230, which was Article 85 of the Foreigners' Law prior to January 1, 2005. See generally Hoffmann, supra note 233, at 200-01 and RENNER, supra note 39, para. 2.4.4, at 31-33 (Längerer Aufenthalt). The notion of a right to citizenship was already introduced in 1993, at least in limited cases, but remained subject to considerable discretion, such as connection with the requirement that naturalization be in the public interest. Stankiewicz, Changing Politics, supra note 46, at 8.

266. See generally Hoffmann, supra note 233, at 201-02 and RENNER, supra note 39, para. 2.5, at 34-35 (Ermessungseinbürgerung).

267. This issue was hotly contested during the debates leading up to the adoption of the new Citizenship Act, supra note 230 . The Red-Green coalition originally wanted to allow it unconditionally, but the CDU/CSU successfully opposed it, on the ground that it "devalues German citizenship." Haas, Roever \& Schmidt, supra note 2, at 166. See also Alice Holmes Cooper, PartySponsored Protest and the Movement Society: The CDU/CSU Mobilises Against Citizenship Law Reform, 11 GERMAN POLITICS 88 (2002); Minkenberg, supra note 34, at 230-32; Green, supra note 176, at 97-98; Stankiewicz, Changing Politics, supra note 46, at 12-13. In the end, the new Citizenship Act both expands and restricts the availability of dual nationality in Germany. RENNER, supra note 39 , para. 1.5 , at 13 .

268. Stankiewicz, Changing Politics, supra note 46 , at 13 , notes that dual citizenship is also tolerated in the case of resettlers, as well as in cases involving applicants who want to keep their old passports for economic reasons, such as to avoid disinheritance. See generally Otto Kimminich, The Conventions for the Prevention of Double Nationality and their Meaning for Germany and Europe in an Era of Migration, 38 GERMAN Y.B. INT'L L. 224 (1996); RENNER, supra note 39, para. 2.6, at 35-39. Germany withdrew from the Convention on the Reduction of Cases of Multiple Nationality and on Military Obligations in Cases of Multiple Nationality, Council of Europe, May 6, 1963 (ETS no. 43), entered into effect Dec. 22, 2002, and has been party to the 1997 European Convention on Nationality, supra note 23, since September 1, 2005.

269. Stankiewicz, Changing Politics, supra note 46, at 5. However, ethnic priority immigration policies have been hollowed out, $i d$. at 16-27, and "other criteria-above all languagegain importance." $I d$. at 27 . See also RENNER, supra note 39, para. 1.4 , at 10 and para. 21 , at 15-20 (explaining changes affecting Statusdeutsche-including Aussiedler and Spätaussiedler--in greater detail).

270. Joppke, supra note 2, at 52. Article 116 of the German Basic Law (Grundgesetz) defines Germans to include certain groups of ethnic Germans living outside the territory of the Federal Republic, notably resettlers from Eastern Europe (Aussiedler) and from the former GDR (Übersiedler). In particular, Article $116 \mathrm{GG}$ provides:

(1) Unless otherwise provided by statute, a German within the meaning of this Constitution is a person who possesses German citizenship or who has been admitted to the territory of the German Reich within the frontiers of 21 December 1937 as a refugee or expellee of German ethnic origin or as the spouse or descendant of such a person. (2) Former German citizens who, between 20 January 1933 and 8 May 1945, were deprived of their citizenship on political, racial or religious grounds, and their descendants, are re-granted German citizenship on application. They are considered as not having been deprived of their German citizenship where they have established their residence in Germany after 8 May 1945 and have not expressed a contrary intention. 
citizenship, while other long-term German residents who wish to naturalize still face limited opportunities to do so.

The liberalization of voluntary naturalization has not come without a cost. In particular, the right to naturalize on the basis of long-term residency may not be exercised if the applicant lacks sufficient knowledge of the German language, if he or she can be shown to have acted against the constitutional order, or if there are grounds for deportation. 271 Further requirements include a written commitment to uphold the liberal democratic German constitutional order, ${ }^{272}$ the ability to support him- or herself, and renunciation of his or her former citizenship. In general, no naturalization is possible unless the applicant shows that he or she is both willing and able to integrate into German society. ${ }^{273}$ Some of these requirements are in tension with Germany's stated goal of curbing the high level of administrative discretion that has characterized previous efforts to liberalize naturalization. In particular, the renewed integration push (discussed in greater detail below in Part IV) suggests that discretion is likely to remain a significant factor. Still, it is significant that the bases upon which discretion may be exercised have been reduced in principle.

University of Würzburg, available at http://www.uni-wuerzburg.de/law/gm00000.html (source of translation). See also 1953 Refugees' and Expellees' Law (Bundesvertriebenen- und Flüchtlingsgesetz). See generally Rainer Münz \& Rainer Ohliger, Long Distance Citizens: Ethnic Germans and Their Immigration to Germany, in PATHS TO INCLUSION: THE INTEGRATION OF MigRANTS IN THE UNITED STATES AND GERMANY 161 (Peter Schuck \& Rainer Münz eds., 1998); Stefan Wolff, Changing Priorities or Changing Opportunities? German External Minority Policy, 1918-1998, in WoLfF, supra note 4, at 183. Germany took special precautions in the EU context to accommodate these special interests. See, e.g., Albert Bleckmann, German Nationality within the Meaning of the EEC Treaty, 1978 COMMON MARKET L. REV. 435; de Groot, supra note 60, at 8 (noting that Germany was the only Member State besides the U.K. to issue a declaration of its nationals for Community purposes).

271. Article 11, Citizenship Act, supra note 230, which was Article 86 of the Foreigners' Act prior to January 1, 2005. This requirement also applies in connection with naturalizations of spouses and minor children and in connection with discretionary naturalizations. Ludvig, supra note 61 , at 507, considers the introduction of language tests for all naturalizations a "backlash" insofar as no proof of language ability was required under the liberalized naturalization procedures that had been introduced in the 1990s. For an historical overview of evolving linguistic and other additional requirements, see Hoffmann, supra note 233, at 195-202.

272. The details to be included in the "declaration of loyalty" are spelled out in Section 85.1.1.1 of the Allgemeine Verwaltungsvorschrift zum Staatsangehörigkeitsrecht (StAR-VwV) (Dec. 13, 2000), GMBI. 2001, 122 [hereinafter Citizenship Regulations]. These Citizenship Regulations are not binding on courts, but merely attempt to direct the authorities in the exercise of their discretion and in this way to achieve a certain level of harmonization. RENNER, supra note 39, para. 1.3 , at 10 .

273. Stankiewicz, Changing Politics, supra note 46, at 15 suggests that "the most difficult question within German society ... [is] into what should integration be accomplished?" In response to this challenge, the German government has, inter alia, prepared a new guide book for immigrants. Among other entries, it lists the döner kebab as Germany's most popular fast food, and provides a large color photo of a garden gnome. Ray Furlong, Germany Welcomes Immigrants with Book, BBC NEWS (Feb. 25, 2004), at http://news.bbc.co.uk/1/hi/world/europe/3487144.stm (last visited Nov. 29, 2005). For a discussion of the positions taken by different parties in regard to integration, see Haas, Roever \& Schmidt, supra note 2, at 168 . Germany's new integration requirements are analyzed in greater detail infra in Part IV. 
One leading scholar places great theoretical weight on the importance of such constraints on state discretion. Joppke argues that, once migrants have "passed the hurdle of entry, ... a democratic logic enters, according to which immigrants become cooperating members of society who are owed equal consideration by the state under whose roof they have come to reside, and on whose protection they now depend."274 Moreover, in his view, such changes constitute "a true constitutional revolution across Western states,"275 which is all the more "astonishing" since it occurs in a realm where "state discretion had previously been at its peak." 276 Ultimately, Joppke argues that this trendcombined with the trend towards "non-discriminatory admissions and residencegranting procedures"-must result in a "decoupling of the citizenry from a particular nation or ethnic group, and a weakening of the entire construct of 'ownership' of the state by that group."277 While legal developments in the EU provide considerable evidence to support his claims about the enhanced status of residence and its approximation to citizenship, they find little support in the new German Citizenship Act, which constitutes a vital step, but hardly a great stride towards the goals Joppke envisions.

For the time being, careful attention is warranted to the implementation and effects of the Citizenship Act. One major question is whether enhanced naturalization opportunities will actually produce a dramatic rise in German naturalization rates. Earlier German efforts to liberalize and encourage naturalization produced only marginal improvements. ${ }^{278}$ To be sure, the naturalization rates quadrupled between 1991 and 1999 in the wake of those reforms, ${ }^{279}$ but overall, naturalization rates have remained relatively low in Germany, compared to other West European countries. ${ }^{280}$ In fact, while naturalizations in Germany rose in 2000 by $30 \%$ to an all-time high of just under 186,700 , they declined steadily every year since then. ${ }^{281}$ Naturalization rates

274. Joppke, supra note 2, at 51.

275. Id. at 52 .

276. Id.

277. Id. at 53.

278. Simplified naturalization procedures were adopted for two categories of persons in 1991, namely for young persons between the ages of 16 and 23, and for long-term residents-in most cases Gastarbeiter-who had lived in Germany for at least 15 years. Ludvig, supra note 61, at 507. These nules were liberalized further in 1993, in the Anderungsgesetz zur Verwirklichung des Asylkmopromisses (Amendment to Implement the Asylum Compromise), which converted the former "entitlement (Regelanspruch) [into] a "definitive right."' Id. However, simplified naturalizations were "de facto abandoned" under the Citizenship Act. Id.

279. Green, supra note 176 , at 95 .

280. Green, supra note 176, at 95-97; Minkenberg, supra note 34, at 230.

281. The German Federal Statistical Office reports that about 178,100 foreigners were naturalized in 2001, 154,500 in 2002, and 140,700 in 2003. DeStasis Press Release, May 24, 2004. In each year, the largest group of persons naturalizing were Turks (40\%), followed by Iranians. Among all persons naturalized in 2003, about $61 \%$ of them were long-term residents. 2003 also saw a big (77\%) jump in the percentage of naturalizations of former German citizens who were deprived of their citizenship for political, racist or religious reasons between 1933 and 1945, and of the descendants of such persons. In 2004 , a total of 127,150 persons were naturalized, which represents 
may jump again when the "third wave of migration [that] started in 1989" reaches the minimum period of required residency, ${ }^{282}$ or around the year 2020 , when children born in Germany and entitled to invoke the jus soli principle must choose which nationality they prefer. Meanwhile, observers are left wondering why German naturalization rates are dropping after the greatest liberalization in German history.

Numerous "practical and psychological disadvantages" 283 have been cited to explain low rates of naturalization. One key practical consideration has been the risk of subjecting male children to conscription. ${ }^{284}$ The new language ability requirement and the cost of naturalization are also likely to affect a number of applicants. ${ }^{285}$ Moreover, the general prohibition of dual citizenship presents special practical and psychological barriers for some, if not many, longterm residents from non-EU countries who might otherwise opt to naturalize. ${ }^{286}$ In practical terms, loss of home country nationality may entail "difficulties of entering or returning to the country of origin, acquiring, selling or inheriting property."287 In psychological terms, the prohibition of dual nationality confronts potential German citizens with loss of identity and self-esteem. ${ }^{288}$ Further, some may perceive the general prohibition against dual nationality as "unwillingness" on the part of the host country to "welcome pluralism and cultural difference." 289 Indeed, retention of home country citizenship may well

a nearly $10 \%$ decline vis-à-vis the preceding year, thus marking the fourth consecutive year of declining naturalization rates since the Citizenship Act entered into force. Deutschland: Rückläufige Einbürgerungszahlen [Dropping Naturalization Rates], 7 MIGRATION UND BEVÖLKERUNG 1 (September 2005). By contrast, in Austria, where recent reforms tightened the citizenship requirements, naturalization rates have risen. Ludvig, supra note 61 , at 509.

282. Ludvig, supra note 61 , at 509 .

283. Ludvig, supra note 61, at 511.

284. Hanagan, supra note 93 , at 400.

285. According to one source, around $20 \%$ of applicants during the first three months of 2000 failed the language tests, while the fees of 250 Euros discouraged others from applying. Ludvig, supra note 61, at 507-08.

286. Randall Hansen, A European Citizenship or a Europe of Citizens? Third Country Nationals in the EU, 24 J. ETHNIC \& MIGRATION STUD. 757 (1998); Ludvig, supra note 61, at 511.

287. Ludvig, supra note 61 , at 511 . In this regard, it is interesting to note that Turkey facilitated the acquisition by its nationals of German citizenship by removing restrictions on acquiring and inheriting property, and by facilitating the process of regaining Turkish citizenship after it had been renounced in connection with naturalization. JOPPKE, supra note 2, at 205.

288. Ludvig, supra note 61 , at 511.

289. Ludvig, supra note 61, at 511 . In course of the Leitkultur ("leading culture") debate that first erupted in 2000, the CDU issued a statement that "German cultural norms" are derived from Christianity and the Enlightenment, classical philosophy, humanism, and Roman law. Haas, Roever \& Schmidt, supra note 2, at 164 . The FDP took the position that aspects of Islam are clearly incompatible with European values. Id. More recently, CDU leader and new chancellor Angela Merkel's statement that "[a]nyone coming here must ... tolerate our Western and Christian roots" was prompted by the broadcast of a Berlin imam who was caught on camera telling worshipers that Germans would "burn in hell" because they were unbelievers. Furlong, Germans Argue Over Integration, supra note 50. In response, the conservative culture minister from Baden-Württemberg, Annette. Schavan, called for a law requiring preaching in mosques to be in the German language. Bernstein, supra note 2 . However, this proposal encountered stiff resistance, and was unambiguously rejected by Mariluise Beck, the Federal Commissioner for Migration, Refugees and Integration 
serve non-Christian immigrants as a source of resistance in the context of debates over the central role of Christianity in German, as well as in European identity. ${ }^{290}$

Judgment as to whether these changes truly represent a paradigm shift ${ }^{291}$ or mere symbolic politics ${ }^{292}$ is beyond the scope of this article, and must await empirical analysis. ${ }^{293}$ Despite some significant changes, the new Citizenship Act maintains a tight clamp on the acquisition of German citizenship by foreigners. Indeed, one unanticipated consequence of the new Citizenship Act is that many thousands of German citizens of Israeli or Turkish origin face the risk of automatically losing their German citizenship. ${ }^{294}$ Still, if such a step away from traditional exclusive modes of belonging can be successfully taken in Germany, a country having an ethno-cultural tradition of membership, then it surely bodes well for the development of more inclusive forms of belonging. Indeed, an optimist might hope that German steps toward multinational citizenship and multicultural tolerance could set an example for the rest of Europe, just as German litigants and courts drove the incorporation of fundamental (human) rights into the EU's legal order. ${ }^{295} \mathrm{~A}$ realist, on the other hand, would be cautious about making any such predictions, particularly in view

(Beauftragte der Bundesregierung für Migration, Flüchtlinge und Integration). Philip Grassmann, Zum Patriotismus Einladen [Invitation to Patriotism], SÜdDEUTSChE ZEITUNG, Nov. 24, 2004, at 56-57.

290. Hanagan, supra note 93 , at 400 , argues that "[m]any immigrant identities originated in conflict with European imperialism, sometimes in struggle against the colonialism of the very nations to which they migrated." This reason seems particularly salient in France, but could also be relevant in Germany, particularly in connection with the Leitkultur debate discussed supra in note 289 and infra in Part IV.A.

291. See, e.g., Green, supra note 176, at 97 ("radical reorientation of citizenship"); Stankiewicz, supra note 46, at 4. Compare RENNER, supra note 39, at $21 \mathrm{n} .110$ (arguing that one cannot speak of a paradigm change so long as jus sanguinus maintains its traditional dominance).

292. Minkenberg, supra note 34, at 237 (arguing that 'the much celebrated 'paradigm shift' is an expression of symbolic politics rather than a reflection of truly substantial and effective changes").

293. In the meantime, there is no shortage of proposals for further liberalization. Ludvig suggests, for example, that "receiver states" could "stock up the budgets of [their] bureaucracies, facilitate administrative practice, lower the fees, reduce the required periods of residence, accept dual nationality, increase information policies and ... turn obtaining [their] nationality into more of a celebratory moment." Ludvig, supra note 61, at 510.

294. Article 25(1) of the Citizenship Act provides for automatic loss of German citizenship upon the volitional acquisition of citizenship of another state. This provision has already affected tens of thousands of German passport holders of Turkish origin who have reacquired their Turkish nationality, as well as a smaller number of Israeli-German dual nationals. See Deutschland: Verlust der deutschen Staatsbürgerschaft droht [Germany: Threatened Loss of German Citizenship], 2 MIGRATION UND BEVÖLKERUNG 2 (March 2005); Israel/Deutschland: Doppelte Staatsbürgerschaft nicht mehr sicher [Germany/Israel: Double Nationality No Longer Certain], 4 MIGRATION UND BEVÖLKERUNG 2 (May 2005).

295. Paradoxically, European public opinion polls have shown that "Germans are significantly less likely than [other] Europeans to name the guarantee of human rights and respect for democracy in Europe as a priority matter for the European Union." Haas, Roever \& Schmidt, supra note 2 , at 157 . However, those authors go on to point out that "[e]lite opinion matters at least as much, more if we consider decisions that result in public policy." Id. at 160. 
of the difficult demographic and employment conditions in Germany today. ${ }^{296}$ Legal reforms do not automatically resolve underlying social tensions. Indeed, under contemporary conditions, the liberalization of citizenship-as well as of migration, discussed below in Part III.B-might even exacerbate such tensions, at least in the short term, particularly given the "welfare chauvinism" and "subculture of resistance" that have been identified as part of the German popular response to growing multiculturalism. ${ }^{297}$ The "underlying controversy over the degree of tolerance to be accorded to diversity remains unresolved,"298 and is likely to stay that way for some time to come.

\section{B. MIGRATION}

Despite strict migration laws during most of the post-war period, more than 10 percent of Germany's current population is foreign. ${ }^{299}$ Germany became one of the world's largest immigrant-receiving countries during the second half of the twentieth century, ${ }^{300}$ even after being virtually closed to foreign workers

296. Minkenberg, supra note 34, at 220; RENNER, supra note 39, at 4.

297. Minkenberg, supra note 34, at 237. See also Furlong, Germans Argue Over Integration, supra note 50 (quoting a politician as saying "[I]f multiculturalism means that it's OK for 30,000 Turks to live in a certain quarter of Berlin, and never leave, and live like they're still in deepest Turkey, then the term is now discredited").

298. Haas, Roever \& Schmidt, supra note 2, at 164. Those authors go on to note, however, that this fact "hardly portends a return to the nationalism of yore. Nor does it differ greatly from similar controversies raging elsewhere in the EU." Id. The issue of headscarves has become increasingly controversial in Germany, as numerous Länder have prohibited the wearing of religious symbols by teachers in public schools. The German Federal Administrative Court (Bundesverwaltungsgericht) upheld one such state law in June 2004. Deutschland: Kopftuchverbot bestätigt [Germany: Head Scarf Prohibition Upheld], 5 MIGRATION UND BEVÖLKERUNG 2, 2-3 (July 2004). See also Das Kreuz mit dem Kopftuch, GOETHE-InSTITUT/QANTARA (2004), available at http://qantara.de (last visited Nov. 21, 2005) (summarizing criticisms of the head scarf decision).

299. I use the term 'foreign' as a rough proxy to encompass the many types of persons who may be counted as falling outside the native-born norm. Both the term and the content of such a composite group are highly contestable. According to official German government statistics, the foreign population has stabilized at 8.9 percent since the end of 1998. Bundesamt für Migration und Flüchtlinge (BAMF), Migration und Asyl in Zahlen (2004), at 65 [hereinafter BAMF 2004]; Bundesministerium des Inneren (BMI) Sachverständigenrat für Zuwanderung und Integration, Migrationsbericht (Nov. 2004), at 26 [hereinafter BMI, Migrationsbericht] (reporting that, between 1992 and 2003, the percentage of foreign population in Germany rose from 8 percent to 8.9 percent, where it has stabilized since 1998). However, the actual population of foreign-born residents is considerably larger, since these figures do not include ethnic Germans-as defined in Article 116 of the Grundgesetz (Basic Law)-who have migrated to Germany from Central and Eastern Europe (Spätaussiedler). While substantial in number, these persons are not treated as foreigners for statistical purposes. According to Minkenberg, supra note 34, at 220, "the net balance of nine million immigrants during [the period from 1954 to 1999] accounts for more than ten per cent of today's population," and "[b]y 1999, immigration to Germany had reached a magnitude that was comparable only to that of the USA" with " 14 per cent of the population . . born outside the country." Id. at 223. See also Joppke, supra note 2, at 62 ("[B]etween 1950 and 1993, the net migration balance has been an astounding 12.6 million, accounting for 80 percent of the country's population growth."). But see Bereinigtes Ausländerregister, supra note 38 (revised official statistics reveal that only 6.7 million non-German nationals were legally residing in Germany at the end of 2004).

300. See, e.g., Minkenberg, supra note 34, at 220. 
from outside the EU after the first energy crisis in the 1970s.

The first wave of post-war immigration consisted of the so-called Gastarbeiter (guest workers) who came between 1955 and 1973.301 These workers, who were expected to be temporary residents, were soon followed by a second wave consisting of their family members. ${ }^{302}$ The illusion that the guest workers and their families would someday return home persisted until the $1980 \mathrm{~s}^{303}$ The third wave of post-war immigration to Germany started after 1980, when some eastern bloc countries-notably Czechoslovakia, Hungary and Poland-allowed some of their citizens to travel to the West. Yet another wave of post-war immigrants came to Germany under its generous asylum procedures. $^{304}$ Indeed, between 1987 and 1992, the number of asylum seekers rose from 57,000 per year to a peak of around 438,000 per year. ${ }^{305}$ The latest wave of immigrants to Germany has arrived since the collapse of the Communism in 1989. These immigrants comprise numerous different groups, including ethnic German resettlers (Spätaussiedler) from Central and Eastern Europe, ${ }^{306}$ Jews from the former Soviet Union, ${ }^{307}$ and persons fleeing wars,

301. Bundesministerium des Inneren (BMI), Zuwanderung - Das neue Gesetz (2005), at 6 [hereinafter BMI, Zuwanderung], available at http://www.bmi.bund.de (last visited Nov. 29, 2005). The guest workers came from Italy, Spain, Greece, Turkey, Morocco, Portugal, Tunisia, and Yugoslavia. Guest worker recruitment was stopped abruptly in November 1973 (Anwerbestop), in the wake of the first energy crisis. By that time, approximately four million foreigners were residing in the Federal Republic of Germany. The halt to recruitment after the 1973 oil crisis-in Germany as elsewhere in Western Europe-"was country-blind, even though the preponderance of certain national or regional origins among immigrants (Turkish in Germany and Switzerland; Algerian or North African in France) arguably was the bone of contention." JOPPKE, supra note 2, at 50. While the focus here is on post-war immigration, Germany has "received immigrants in growing numbers" since the late nineteenth century. Brinkmann, German Migrations, supra note 36, at 140.

302. In 1999, 30 percent of all foreign residents in Germany had been living there for $\mathbf{2 0}$ years or more. Ludvig, supra note 61 , at 500 . At present, approximately 1.5 million foreign (that is, non-citizen) minors are living in Germany, of whom approximately two-thirds were born there to one or more non-German parents.

303. The Turks in Germany "abandoned the discourse of return and replaced it with talk of permanent settlement and political rights" in the 1980s. KASTORYANO, supra note 42 , at 117.

304. Asylum has been a particularly salient issue in Germany, whose post-war asylum lawembedded in Article 16 of the Basic Law-was the most liberal in Europe and granted a higher level of protection than guaranteed by the Convention relating to the Status of Refugees, July 28, 1951, 189 U.N.T.S. 137, as modified by the Protocol Relating to the Status of Refugees, Jan. 31, 1967, 606 U.N.T.S. 267. Minkenberg, supra note 34 , at 223 ; Stankiewicz, supra note 46 , at 9 . The number of asylum seekers in Germany rose dramatically and provoked a political crisis in the immediate aftermath of the collapse of Communism. Green, supra note 176, at 92-95.

305. After Germany's asylum law was tightened up in 1993, the number of annual petitions dropped again. 50,500 asylum petitions were filed in 2003. At present, some 1.1 million people live in Germany who are recognized or seeking recognition as refugees. BMI, Zuwanderung, supra note 301 , at 6 . After the recruitment of guest workers was banned in the 1970s, "seeking asylum was, from the immigrant's perspective, easier and more beneficial than choosing the other possible legal path into Germany through family reunion." Stankiewicz, supra note 46 , at 9.

306. The peak years for ethnic German migration were 1989 and 1990, when 380,000 and 400,000 persons respectively immigrated to Germany. All told, around 4.4 million such persons have migrated to Germany since 1950 . BMI, Zuwanderung, supra note 301, at 6 .

307. Since 1990, around 188,000 Jewish persons immigrated to Germany from the former Soviet Union, mainly from Russia and Kazakhstan. BMI, Zuwanderung, supra note 301, at 6 . 
particularly in the Balkans, Africa, and the Middle East. ${ }^{308}$ At present, some 7.3 million foreigners live in Germany, of whom more than half have spent ten or more years there. ${ }^{309}$

Germany's new Immigration Act signals the formal end of decades of official insistence that Germany was not a "country of immigration." 310 The discrepancy between de facto immigration and its political denial, which a leading scholar has labeled the "single most enduring puzzle in the German immigration debate,, 311 has been significantly narrowed by the reforms passed under the Schröder government (1995-2005). Although reforms were finally passed into law during an extended period of SPD-led coalition government, the major parties on both the Left and the Right have invoked the non-immigration trope in recent decades. ${ }^{312}$ Indeed, even Chancellor Schröder, on whose watch the German legal frameworks for both citizenship and migration have undergone historical reversals, has stressed that the new Immigration Act was designed to enable the government to regulate and in particular to limit migration, rather than to encourage it. ${ }^{313}$ This statement by a leading reformer suggests that the underlying fear of migration ${ }^{314}$ may not have subsided, but rather merely been suppressed in view of the "demographic reality of aging societies with social security and health care systems under the threat of collapse."315

308. See sources cited supra in note 42 .

309. BMI, Zuwanderung, supra note 301, at 6 .

310. See sources cited supra in note 262 . Minkenberg, supra note 34 , at 223 , calls this policy "a Lebensluege (a false myth) of the Federal Republic" and explains its persistence "as a feature of symbolic politics in the face of globalisation and loss of national control."

311. JOPPKE, supra note 2, at 62.

312. Brinkmann, German Migrations, supra note 36 , at $140 \mathrm{n} .1$, notes that "[ $[\mathrm{t}] \mathrm{his}$ was the position of the CDU-led government between 1982 and 1998," but hastens also to add that "shortly before its demise in 1982, the interior secretary of the SPD/FDP coalition government declared that 'the Federal Republic is not a country of immigration and that it should not become one"' (quoting Barbara Marshall, The New Germany aNd Migration IN EUROpe 13 (2000)). By the same token, "all parliamentary parties put forward proposals to liberalize citizenship law" in the 1990s. Stankiewicz, supra note 46, at 10 . See also Green, supra note 176, at 40-44; Imke Kruse, Henry Edward Orren \& Steffen Angenendt, The Failure of Immigration Reform in Germany, 12 GERMAN POLITICS 129 (2003); Malcolm MacLaren, Framing the Debate over the German Immigration Bill: Toward Reasoned Policymaking, 2 GERMAN L. J. 16 (2001).

313. To be fair, it may be that this statement was made with the aim of smoothing passage of the Immigration Act, supra note 231. In his first speech as Chancellor in 1998, Schröder stated that "he did not see the basis of the national self-conception in traditions of descent, but rather in the certainty of German democracy." Stankiewicz, supra note 46, at 19 (citing DIE WELT, Feb. 11, 1998).

314. See, e.g., Brinkmann, German Migrations, supra note 36, at 140 ("Migration by nonGermans was perceived by the state and the public as a problem, often even as a threat.").

315. Brinkmann, German Migrations, supra note 36, at 149 (noting that "Germany is not the only country to face the contradiction between the obvious long-term need for migration to save social networks and to fill jobs on the one hand and, on the other, popular resentment against immigration"). See also BBC NEWS (July 9, 2004), Germany approves immigration law, at http://news.bbc.co.uk/1/hi/world/europe/3880521.stm (last visited Nov. 29, 2005) ("Supporters say law is crucial as the country battles with an ageing population and a skills shortage" and addresses "Germany's need for skilled migrant workers from outside the EU.") [hereinafter BBC NEWS, Germany approves]. 
Although debates over multiculturalism in Germany continue to rage, 316 the last formal bastion of official resistance to Germany's multicultural fate fell in July 2004, with the passage of the new Immigration Act (Zuwanderungsgesetz) ${ }^{317}$ by an overwhelming majority of the Bundestag after a tortuous journey through the legislature and the German Constitutional Court (Bundesverfassungsgericht). ${ }^{318}$ The Immigration Act has been reported as Germany's "first immigration law," 319 but it is more accurate to say that it is Germany's first comprehensive legal framework for immigration. Taken together with the Citizenship Act, the Immigration Act constitutes a serious attempt to adapt the German legal framework to existing conditions, and to address current as well as future needs. An assessment of the impact of the new Immigration Act must await further scrutiny, since it is too soon to draw lasting conclusions about its implementation, particularly at a time of regime change and economic difficulties. This proviso aside, the following discussion considers experience since the Act entered into force on January 1, 2005, after examining the main features of Germany's new legal regime.

The new Immigration Act constitutes Germany's second major step, after adoption of the Citizenship Act, towards greater openness and inclusiveness. Like the Citizenship Act, Germany's new law on migration marks numerous historical departures. At the same time as recognizing its historical significance, however, it must also be acknowledged that this new regime is unlikely to prove a stable one. Expanding EU competence and activity in the field of migration renders developments at the level of the Member States more tentative and vulnerable to change in the short run. For this reason, one leading German expert on migration law has predicted that the new Immigration Act will require substantial revision within the short span of two years. ${ }^{320}$ But notwithstanding

316. See the discussion of the Leitkultur debates supra in note 289. Various other controversies relating to the integration of migrants are discussed infra in Part IV.A.

317. Supra note 231.

318. The passage of the Immigration Act put an end to four years of "bitter struggle, in which the conservative opposition fought the original government proposals in both the parliament and in the courts." BBC NEWS, Germany approves, supra note 315. The Immigration Act was initially passed into law in June 2002. Shortly thereafter, six "opposition-ruled state governments" brought a case to the German Constitutional Court (Bundesverfassungsgericht), arguing that "the law should be declared invalid because of the unorthodox voting procedures by which it had been passed." Kruse, Orren \& Angenendt, supra note 312, at 134. The Court declared the Immigration Act invalid in December 2002, shortly before it was due to enter into force on January 1, 2003. Decision of the Bundesverfassungsgericht [BVerfG] (Federal Constitutional Court) of December 18, 2002, 37 Entscheidungen des Bundesverfassungsgerichts [BVerfGE] (Decisions of the BverfG) 271 (F.R.G.), available at http://www.bverfg.de/entscheidungen (last visited Nov. 21, 2005). The Act was re-introduced in unaltered form, but subsequently altered in numerous respects. See Kruse, Orren \& Angenendt, supra note 312, at 134-43 (discussing the topics covered in the reopened debate over the content of the Immigration Act).

319. BBC NEWS, Germany approves, supra note 315.

320. Günter Renner, Das Staatsangehörigkeitsrecht nach der Reform reformbedürfitg? [Is the Reformed Citizenship Act in Need of Further Reform?], 24 ZEITSCHRIFT FÜR AUSLÄNDERRECHT UND AUSLÄNDERPOLITIK 176 (2004). 
the overarching question of its ability to stand the test of time, Germany's new Immigration Act deserves to be analyzed on its own terms.

The 2004 Immigration Act is an omnibus bill that adds two new laws to the books, repeals some old laws, and revises a number of existing laws (including the Citizenship Act). The most important new law, for present purposes, is the Residence Act (Aufenthaltsgesetz), ${ }^{321}$ which replaces the former Foreigners' Act (Ausländergesetz). ${ }^{322}$ The analysis below focuses on the new Residence Act and related regulations, since these will have the greatest impact on current and new immigrants from non-EU countries. ${ }^{323}$

A few words about terminology are needed before proceeding to examine the principal changes that have been introduced. The German designation Zuwanderung was chosen in lieu of Einwanderung as the title for the new Immigration Act. The connotations of these two terms are different, despite the fact that both would be rendered in English as 'immigration'. During the protracted debates leading up to adoption of the Immigration Act, the (adopted) term Zuwanderung was preferred by those urging a more restrictive posture towards immigration, since it implies "unwanted immigration that is tolerated for constitutional and moral-political reasons." 324 The rejected term Einwanderung, on the other hand, "connotes actively solicited, wanted immigration." 325 Given this background, one might expect the new Zuwanderungsgesetz to hew to tradition, yet this is far from the truth. Paradoxically, the title ultimately chosen for the new law is at odds with its content, at least in regard to the concrete provisions of the new Residence Act pertaining to labor migration. The historical debate over terminology is noted here as a reminder that the new law is a hard-fought compromise between wellarticulated positions across the political spectrum, and that conceptual debates in this complex field must take second place to concrete analysis of legal provisions and their implementation over time.

In substantive terms, the new Residence Act introduces a number of important reforms aimed at simplifying the rules and procedures governing immigration. The former complex system of five "residence titles" has been reduced to just two: the limited-term residence permit (Aufenthaltserlaubnis) ${ }^{326}$

321. Article 1 of the Immigration Act, supra note 231, sets forth the new Gesetz über den Aufenthalt, die Erwerbstätigkeit und die Integration von Ausländern im Bundesgebiet (AufenthG) (Act on the Residence, Economic Activity and Integration of Foreigners in the Federal Territory) [hereinafter Residence Act]. The Residence Act entered into force on January 1, 2005.

322. The Immigration Act repealed the Gesetz über die Einreise und den Aufenthalt von Ausländern im Bundesgebiet (AuslG), BGBl I 1990, 1354, 1356 (Law on Entry and Stay by Foreigners in Federal Territory) (9 July 1990) [hereinafter Foreigners' Act] and related regulations.

323. Article 2 of the Immigration Act, supra note 231, sets forth the new Gesetz über die allgemeine Freizügigkeit von Unionsbürgern (FreizügG/EU) (Act on the General Freedom of Movement for EU Citizens), which brings German law into compliance with EU rules on free movement of persons.

324. JOPPKE, supra note 2, at 97.

325. JOPPKE, supra note 2, at 97.

326. Residence Act, supra note $321, \S 7$. 
and the unlimited-term settlement permit (Niederlassungserlaubnis) ${ }^{327}$ These, in turn, are functionally linked to the recognized purposes of residence in Germany (that is, education, employment, family reunification, and humanitarian considerations) ${ }^{328}$ The new Immigration Act creates a procedure under which students are permitted to remain in Germany for up to one year after completing their studies, in order to gain work experience. ${ }^{329}$

Some of the most significant changes introduced by the Residence Act reflect an interest in attracting or retaining skilled labor. In general, it will be considerably easier for "highly qualified persons" to immigrate to Germany, whereas the general ban on immigration by "unqualified" persons, as well as on those having "low" or ordinary qualifications, remains in effect. ${ }^{330}$ As for the favored "highly qualified" persons, they may be granted permanent residence from the outset, under a unified ("one-stop government") procedure ${ }^{331}$ that replaces the prior cumbersome dual procedure that separated the process of seeking permission to work from the process of seeking a residence permit. ${ }^{332}$ Family members of "highly qualified" persons may also work under Germany's new rules. ${ }^{333}$ In addition, self-employed persons may receive a residence permit if they invest at least one million Euros and create at least ten jobs.

Asylum and family reunification continue to play an important role in German immigration law. However, these topics are already covered to a large extent by applicable provisions of international and EU law, and for that reason are not considered here in detail. It does bear mention, however, that the Residence Act extends the new integration requirements (discussed below in Part IV) to certain family members of persons entitled to reside in Germany under either asylum law or the rules on repatriates (Spätaussiedler).

Finally, in institutional terms, the Immigration Act created a new Federal Office for Immigration and Refugees (Bundesamt für Migration und Flüchtlinge), which takes over the responsibilities of the former Federal Office for the Recognition of Foreign Refugees. ${ }^{334}$ This new office-known by its acronym BAMF - will maintain the central registry of aliens and collect data relating to migration patterns, but will also develop and implement the new

327. Residence Act, supra note $321, \S 9$.

328. Residence Act, supra note $321, \S 1$.

329. Residence Act, supra note $321, \S 16(4)$.

330. Residence Act, supra note 321, § 39(4). However, some special rules apply to socalled "qualified" persons. For one, there is an exception to the general ban that permits the authorities to grant qualified persons a residence permit where it would be in the public interest to do so. Residence Act, supra $\S 18(4)$. Second, there is a special rule granting priority to qualified nationals in regard to jobs for which no German person is available. Residence Act, supra $\S \S$ 39(2)(b), 39(6).

331. Residence Act, supra note $321, \S 39(1)$.

332. Residence Act, supra note $321, \S 19$. In other words, highly qualified persons are not required to wait for five years before applying for permanent residency. Id.

333. Residence Act, supra note $321, \S 29$.

334. Residence Act, supra note $321, \S 75$. 
integration programs. ${ }^{335}$ This institutional development marks an important change from the past, when "no federal agencies [were] specifically designed to administer migrant-related tasks."336 BAMF, which is an agency of the Federal Ministry of the Interior (BMI), does not replace the independent Federal Commissioner for Migration, Refugees and Integration (Beauftragte für Flüchtlinge und Integration), who since late 2005 has had cabinet status as Minister for Integration.

IV.

INTEGRATION: TOWARDS A NEW PARADIGM?

Germany's new laws on citizenship and on immigration attest to heightened, albeit not entirely new concerns with integration and security. Indeed, the limitations imposed on the pragmatic openness of Germany's new Citizenship and Immigration Acts are directly attributable to such concerns. These are, in a sense, the political price to be paid for liberalization. In particular, the new Immigration Act (including its amendments to the Citizenship Act) aims to balance the needs of Germany's labor market against its security needs, by making it easier for the authorities to deport people who are suspected of supporting political violence. This section examines the new rules that have been put in place, and considers available evidence regarding their implementation to date.

The perennial topic of integration raises some of the most controversial questions in the field of migration and citizenship. ${ }^{337}$ Scholars have long recognized that there is no single model of integration. ${ }^{338}$ From this theoretical perspective, Germany's approach to integration-its "incorporation regime"consists of "strategies, policy instruments and organizational arrangements" that differ substantially from those found in other countries ${ }^{339}$ and reflect the peculiarities of its own notions about membership, as well as about state-society relations. An emerging alternate theoretical perspective emphasizes the commonalities that are visible through the lens of comparative analysis, ${ }^{340}$ and raises questions about whether convergence is occurring. The recent emergence of EU guidelines pertaining to the integration of migrants in EU Member States, ${ }^{341}$ which appears to provide some support for each of these theoretical

335. Id. BAMF also plays a central role in regard to asylum. In particular, it decides asylum petitions and carries out the asylum-related provisions of the Schengen regime.

336. SOYSAL, supra note 76 , at 77 .

337. Davy, supra note 46 , at 123 (noting that integration "became the buzzword in Germany's recent migration policy").

338. See, e.g., FAVELL, supra note 2; KASTORYANO, supra note 42; SoYSAL, supra note 76.

339. SOYSAL, supra note 76 , at 2-6.

340. See, e.g., Joppke \& Morawska, supra note 3, at 6-7 (arguing that the "popular notion of national models of immigration integration has obscured the similarities of integration approaches and assimilation concerns across liberal states").

341. Common Basic Principles for Immigrant Integration, supra note 213. See generally Kees Groenendijk, Legal Concepts of Integration in EU Migration Law, 6 EUR. J. MIGRATION \& L. 
perspectives, raises further questions about the relationship between developments at EU level and in its Member States.

\section{A. GETTING TOUGH: INTEGRATION}

With regard to integration, Germany appears to be taking a new get-tough policy. ${ }^{342}$ But despite the presence of new rules, resources and rhetoric, it bears asking how new any of this really is. In fact, the need to promote better social integration of guest workers was already on the German agenda in the $1970 \mathrm{~s},{ }^{343}$ and stayed there during the 1980 s and the 1990 s. $^{344}$ Initiatives varied widely from one state (Land) to another, even after the establishment of the Federal Commissioner for Foreigners' Affairs (Ausländerbeauftragte der Bundesregierung) in 1981. Early efforts consisted largely of pragmatic attempts to integrate foreigners into existing social structures, but fell far short of cultural assimilation. The limitations of the postnational integration postulated by Soysal became painfully apparent during the xenophobic violence against immigrant families in Solingen and Mölln in the early $1990 \mathrm{~s},{ }^{345}$ and have returned with renewed force after the murder of Dutch filmmaker Theo van Gogh in mid-2004 and the outbreak of violence in France in late 2005 and in Denmark in early 2006.

The question of integrating immigrants has been a particularly fraught one in post-war Germany. Policy-makers shied away from the stance of insisting that post-war immigrants take on "membership in a tainted nation." 346 Another factor limiting the push towards integration of immigrants prior to German unification was the Federal Republic's telos of achieving unification of all Germans, defined in ethno-cultural terms. These historical conditions made it difficult for Germans to contemplate citizenship for immigrants, and resulted in a situation in which neither the Left nor the Right expected post-war immigrants to assimilate. Rather, German political elites largely converged on a "mellow concept of integration" based on the idea of a "relaxed coexistence" without any loss of identity on the part of the immigrants. ${ }^{347}$ This tendency to preserve

111 (2004); Yongmi Schibel, Integration and the Role of Local Authorities, 5 EUR. J. MIGRATION \& L. 99 (2003); Katja S. Ziegler, Editorial: Integrating Integration?, 7 EUR. J. MIGRATION \& L. 119 (2005).

342. Residence Act, supra note $321, \S \S 43-45$.

343. Minkenberg, supra note 34 , at 220.

79.

344. This discussion is based on the analysis found in SoYSAL, supra note 76, at 61-64, 77 -

345. JOPPKE, supra note 42 , at 186 . These tragic events galvanized the immigrant (and particularly the Turkish) community in Germany, as well as the German political parties, and sparked discussions that ultimately resulted in passage of the new Citizenship Act with its "civicterritorial redefinition of the traditional German model of ethno-genealogical citizenship." Id.

346. JOPPKE, supra note 42, at 187. Karl Jaspers expressed the "delegitimation of nationhood" in the early years of the Bundesrepublik, when he proclaimed the end of the nation-state and pronounced it "the disaster (Unheil) of Europe and of all continents." Id.

347. JOPPKE, supra note 42 , at 188 . Thalheimer points to a vast gulf between 'integration' which implies fitting into society, and 'assimilation' which implies dissolving into society. Philipp 
difference was bolstered by the "few immigrant voices in the integration debate," whose demands for "equal co-existence" between immigrants and Germans also tended to keep these groups apart. ${ }^{348}$ Immigrant activists in Germany were more inclined to see citizenship as a "means of guaranteeing residence and the political rights associated with it [than] of ensuring a cultural integration."349 The growing influence of Islamic organizations in Germany has furthered this tendency, since they opposed assimilation and pushed towards "an institutionally complete parallel society." 350

This rough equilibrium has been disrupted by recent legal reforms, which have taken the first real step towards decoupling citizenship from ethno-cultural membership in the German nation, and thrown the doors open to at least some categories of labor migrants. As noted earlier, both the new Citizenship and Immigration Acts hang an 'integration' price tag on the liberalizations they offer. This is one, but by no means the only reason why debates on integration and multiculturalism have erupted once again in Germany. The Federal Government has taken concrete steps to facilitate, and simultaneously to push for further integration. As one government expert pointedly put it, "integration is particularly important for Turks, who make up more than 25 per cent of all foreigners living in Germany and are citizens of a country that aspires to EU membership." 351

The new demand that immigrants demonstrate their willingness and ability to integrate applies both in connection with citizenship and immigration. In practical terms, the integration requirements overlap. However, they may play out differently in these two contexts, and considerable uncertainty remains over how the new requirements will be implemented. These uncertainties are exacerbated by the fact that the Länder may, and in fact do implement the applicable federal laws in a non-uniform manner. ${ }^{352}$

An overarching question concerns the precise nature of the German society

Thalheimer, Migration und Integration am Beispiel Türkei, in BUNDESAMT FÜR MIGRATION UND

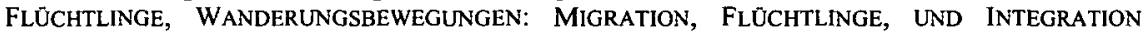
[FEDERAL OfFice OF Migration and Regugees, Migration MOVEMEnTs: Migration, REFUGEES, AND INTEGRATION] (2003), at 105.

348. JOPPKE, supra note 42, at 189.

349. KASTORYANO, supra note 42 , at 117.

350. JOPPKE, supra note 42 , at 215.

351. Thalheimer, supra note 347 , at 102.

352. The Citizenship Regulations, supra note 272, allow Länder some leeway to make their own rules, for example, in regard to language tests, dual nationality, and residence of less than eight years (in the case of voluntary naturalization). RENNER, supra note 39, para. 1.3, at 10. For examples of how these local variations play out in practice, see, for example, Ludvig, supra note 61, at 507 (noting some "high discrepancies ... in ... naturalisation rates"); RENNER, supra note 39, para. 2.4.4, at 32-33 (observing different standards in regard to linguistic capability). Ludvig, supra at 508 , argues that there are many reasons why naturalization rates differ widely from one Land to another, including "the duration of the naturalisation processes, the structures of bureaucratic organisation and decision-making in the single cases, information policies and the differences in the level and arnount of human resources." 
into which immigrants are expected to integrate. ${ }^{353}$ In the Leitkultur debate that first erupted in 2000, there was "nothing specifically 'German' about the culture that immigrants were to be asked to share," indeed the "only non-procedural element of this culture (next to the language requirement that no state qua state can do without) was [the CSU's] commitment to 'Christian-occidental culture' which implicitly excluded Islam." 354 On this basis, Joppke argues that the only "exclusionary potential" inherent in Germany's "civic-nationalist turn" is to "'thicken' the liberal-democratic integration requirement and to make the liberal state for liberal people only." 355 Yet it is precisely this requirement that collides with religious fundamentalism and the anti-feminist practices of some minority groups in Germany. In fact, a major controversy of this nature erupted in early 2006 over an arguably anti-Muslim questionnaire that one of the Länder (state governments) prepared for persons seeking to naturalize in Germany. ${ }^{356}$

Language ability, which is the front line of integration, plays a central role in both the naturalization and immigration contexts. It is essential to one's ability to participate in German society, and is the key to education and successful integration into the labor market. ${ }^{357}$ While there is little disagreement about the importance of language training for integration and social harmony, concerns about education appear to be a strong factor behind Germany's intensified commitment to language training. The PISA process dealt Germany quite a shock when it revealed that German school graduates made a poor showing in cross-European comparison. ${ }^{358}$ There is some data indicating that the foreign population among children in German schools is

353. Stankiewicz, supra note 46 , at 15 .

354. Joppke, supra note 2, at 56-57. The Leitkultur debate has resurfaced. See, e.g., "Bitte, lernt Deutsch!" Debatte über Integration, Werte, Nation ["Please learn German!" Debates over Integration, Values, and Nation], FranKfuRTER ALlgEMEINE ZEITUNG, Nov. 22, 2004, at 1 (reporting statements by leading CSU and CDU politicians at a CSU party convention).

355. Joppke, supra note 2, at 56-57.

356. The Baden-Württemburg state (Land) government prepared a questionnaire ostensibly designed to ascertain whether the views and values of candidates for naturalization are compatible with the German Basic Law (Grundgesetz). This questionnaire, which inter alia asks pointed questions about religion, gender relations and homosexuality, has offended Germany's Muslim population in particular, and caused general uproar across the political spectrum. See Gejohle und Zwischenrufe [Hoots and Cat Calls], KöLNER STADT-ANZEIGER, Jan. 20, 2006, at 6 (describing the atmosphere in the Bundestag during debates over the 'Stuttgart Directive'). Many politicians, including Turkish-German politicians on the Left and Right, have labeled the questionnaire discriminatory and called its legality into question. See, e.g., Ein ganz anderer Vorschlag [An Entirely Different Proposal], KÓLNER STADT-ANZEIGER, Jan. 20, 2006, at 6; Fragebögen ändern nicht das Verhalten [Questionnaires Do Not Alter Behavior], KOLNER STADT-ANZEIGER, Jan. 20, 2006, at 6; Zweifel an der Rechtsmäßigkeit [Doubts About Legalilty], KÖLNER STADT-ANZEIGER, Jan. 20, 2006, at 6 .

357. BAMF 2004, supra note 299 , at 83.

358. According to the former German Federal Minister for Education and Research, "[a] country with the top economic and political significance of Germany belongs at the top of the league and cannot be satisfied with an education system performing at the OECD average level-never mind below it." Edelgard Bulmahn, PISA: The consequences for Germany, OECD Observer 231/232 (May 2002), available at http://www.oecdebserver.org (last visited Nov. 21, 2005). 
partly responsible for Germany's poor showing in the PISA studies. ${ }^{359}$ Acute public concern about basic education is at the very least compatible with a greater push towards linguistic competence for immigrants. ${ }^{360}$ This linkage seems even more compelling, in view of official statistics showing that Turks living in Germany are poorly educated, relative to Germans and other immigrants, and that they have higher rates of unemployment. ${ }^{361}$ To be sure, Thalheimer also notes the tendency of this gap to shrink as second- and thirdgeneration Turks become better educated and improve their socio-economic position vis-à-vis their parents. ${ }^{362}$ Still, there are signs of a lingering perception of Turks as an entrenched underclass. In this context, linguistic competence is seen as a crucial intervention to break a cycle of dependency.

In the naturalization context, Article 11 of the Citizenship Act makes clear that the right to citizenship is not available if the applicant lacks sufficient knowledge of the German language. The language requirements are spelled out in detail in the Citizenship Regulations (StAR-VwV), which demand not only the ability to speak in daily life, but also to communicate with authorities in a manner appropriate to one's age and education. ${ }^{363}$ Early debates over the required level of spoken, reading and written competence ${ }^{364}$ have been largely

359. For example, Thalheimer's study of Turkish migrants in Germany shows "deficiencies in education and vocational training," relative to the German population, among Turkish migrants (and particularly among Turkish women) living in Germany. Thalheimer, supra note 347, at 102-03. The implication of this study is that the poor performance of migrant populations is exerting downward pressure on aggregate German performance in the PISA studies. This effect is more clearly demonstrated in a report prepared by the German PISA Consortium, which shows a clear and dramatic link between school performance, as measured by the PISA process, and the migration status of the affected school children. Manfred Prenzel et al., PISA 2003: Ergebnisse des zweiten internationalen Vergleichs: Zusammenfassung [Results of the Second International Comparative Study: Summary], at 25-26, available at http://www.pisa.ipn.uni-kiel.de/Ergebnisse_PISA_2003.pdf (last visited Nov. 21, 2005). See also Bericht der Beauftragten der Bundesregierung für Migration, Flüchtlinge und Integration über die Lage der Ausländerinnen und Ausländer in Deutschland [Report of the Federal Commissioner for Migration, Refugees and Integration on the Status of Foreigners in Germany] (August 2005); Ingrid Gogolin et al., Report der Bund-Länder-Kommission für Bildungsplanung und Forschungsförderung über Förderung von Kindern und Jugendlichen mit Migrationshintergrund [Report of the Federal-State Commission on Education and Research on Support for Migrant Children and Youth], (2003) (proposing measures to meet the special needs of young members of Germany's migrant community).

360. Seyran Ates, a leading Turkish-born legal activist in Berlin, supports linguistic integration, but argues that this will not suffice to prevent "a shockingly high number of thirdgeneration children from becoming bilingual illiterates, many of whom are destined for a career as social welfare recipients." Integration funktioniert nur miteinander [Integration is a Two-Way Street], SÜDdEUTSCHE ZEITUNG, Nov. 24, 2004, at 2.

361. Thalheimer, supra note 347 , at 102-04.

362. Id.

363. Citizenship Regulations, supra note 272 . The Regulations state explicitly that it is insufficient to "simply get by" in spoken German, and additionally require the ability to read an everyday text in German. They also contain detailed criteria regarding acceptable forms of proof of language competence.

364. See, e.g., RENNER, supra note 39, para. 2.4.4, at 32-33 (discussing at length the different linguistic standards imposed in various laws and arguing that the new requirements fall somewhere in between the minimum and maximum levels required in other contexts). Renner argues 
resolved, at least in principle. The head of the Federal Office for Migration and Refugees (BAMF) indicated in January 2005 that a "relatively high level" of German linguistic ability would be required "for day-to-day" communications, and reiterated the need to demonstrate written as well as spoken knowledge of German. ${ }^{365}$

In the immigration context, the integration requirement has been crystallized under the Residence Act, which provides for the creation of a new system of integration courses designed to impart language competence as well as basic familiarity with history, culture, and the legal system. ${ }^{366}$ While the law often speaks of participation in the new integrations courses as an entitlement, it is clearly obligatory for new migrants (including Jews ${ }^{367}$ and ethnic Germans), as well as for certain foreigners already living in Germany, insofar as places are available for them. ${ }^{368}$ In fact, sanctions are attached to failure to participate in the required courses. In particular, renewal of a residence permit is conditioned upon participation in such a course (or otherwise satisfying the requirements), ${ }^{369}$ and social benefits may be cut (up to $10 \%$ ) for failure to participate in a mandatory integration course. ${ }^{370}$

The courses themselves will be developed and implemented by the new BAMF, in accordance with extensive guidelines laid down in the Ordinance on Integration Courses, which entered into effect January $1,2005 .{ }^{371}$ The courses involve a total of 630 hours of instruction: 600 hours of language and 30 for the orientation component. The bulk of the costs will be born by the Federal Government, which estimates that it will cost 188 million Euros per annum for new immigrants (including repatriated ethnic Germans), plus an additional 76

further that ideally, the test should be whether the applicant possesses sufficient ability to understand the fundamental principles of political life and participate therein, particularly by voting. $I d$. At the very least, however, he suggests that the standard must encompass age-appropriate ability to get along in daily life and at work. Id. See also Davy, supra note 46, at 135-36, 142-43 (discussing the history of and further ambiguities in the new language requirements).

365. Krägenow, supra note 46.

366. Residence Act, supra note $321, \S 43$.

367. The federal government announced soon after the Immigration Act entered into force that it would apply the integration requirements to Jewish immigrants and place more emphasis than in the past on German language ability. This decision was made in the context of a rising number of Russian-speaking Jews and older petitioners who were past working age. However, a representative of the Federal Ministry of the Interior (Bundesministerium des Innern) said that "certain groups" of Jewish immigrants would be able to obtain residence permits outside the framework of the new law." New regulations are to be worked out with the Zentralrat der Juden (Jewish Central Council). Jüdische Einwanderer sollen sich integrieren [Jewish Immigrants Should Integrate], FRANKFURTER AllgemeINE ZeITUNG, Jan. 20, 2005, at 1.

368. The right to participate in an integration course is spelled out in $\S 44$ of the Residence Act, supra note 321 , while the obligation is spelled out in $\$ 44 a$. The affected groups of current resident foreigners under Article $44 \mathrm{a}$ of the Residence Act are those drawing unemployment benefits and those having "special integration needs."

369. Residence Act, supra note $321, \S 8(3)$.

370. Residence Act, supra note $321, \S 44 \mathrm{a}(3)$.

371. Verordnung über die Durchführung von Integrationskursen für Ausländer und Spätaussiedler (IntV), BGB1 2004 Part I, no. 68, at 3370 (Dec. 17, 2004). 
million Euros to make the courses available to the 50,000 to 60,000 foreigners already living in Germany. Course participants are expected to contribute towards the courses on a graduated basis, according to their financial ability. For their part, the Länder are expected to cover the cost of child-care incurred by participants in these courses. Former Federal Interior Minister Otto Schily stated that this program "does not make up entirely for the variety of shortcomings of integration policy in the past," and has urged Länder and municipal governments to step up their provision of measures aimed at integrating immigrants already living in their territories. ${ }^{372}$ Today, as in the past, the Länder offer different levels and types of support and programs to their foreign populations.

The contemporary German discourse on integration is not limited to linguistic competence, however. The official rhetoric calls for "intercultural competence" in which both immigrants and those already living in Germany make an effort to get to know and learn how to get along with each other. ${ }^{373} \mathrm{~A}$ number of different types of programs are offered, ranging from intercultural training to advice on how to manage day-to-day life in Germany. Another important aspect of German policy recognizes that immigrants' experience of discrimination has a direct effect on their willingness to integrate. Every instance of discrimination has the potential to push immigrants in the direction of ethnic segregation. ${ }^{374}$ Public opinion data from Turkish residents in Germany in the year 2000 revealed that 91 percent of the persons surveyed viewed intolerance of foreigners (Ausländerfeindlichkeit) as the most important problem that politicians should address. ${ }^{375}$ More than one third of the surveyed Turks cited experience with discrimination in connection with securing school admission, a job, or housing. ${ }^{376}$ Rights-based strategies may provide immigrants with a constructive avenue for seeking redress of their grievances in the future. ${ }^{377}$

It is too soon to assess the impact of the integration requirements on the targeted populations. Yet this empirical lacuna must not stand in the way of asking how the new integration regime squares with former German policies and practices regarding immigrant integration, or how it is likely to be received. On

372. Bundesministerium des Inneren (BMI), Schily: Principle of "Give and Take"; Ordinance on Integration Courses Clearly Outlines Immigrants' Rights and Duties for the First Time (Dec. 1, 2004), available at http://www.bmi.bund.de (last visited Nov. 21, 2005).

373. BAMF 2004 , supra note 299 , at 84 .

374. Thalheimer, supra note 347 , at 105 .

375. Thalheimer, supra note 347 , at 104.

376. Thalheimer, supra note 347 , at 104.

377. The long-awaited German antidiscrimination legislation (Gesetz zum Schutz vor Diskriminierung) implementing EU directives aimed at combatting race- and gender-based discrimination is pending. A bill was passed by the Bundestag (lower house) on June 17, 2005, but rejected by the Bundesrat (upper house) on July 8,2005 . The process was subsequently put on hold by the federal elections in September 2005 , and is due to be taken up again by the new Grand Coalition government under Chancellor Angela Merkel. 
the one hand, there is a high degree of rhetorical continuity with earlier statements calling upon Germans and immigrants alike to meet each other halfway on the road towards social integration, ${ }^{378}$ as well as practical continuity with earlier policies designed to further progress towards this goal. ${ }^{379}$ On the other hand, however, there are some reasons to expect real change in the wake of Germany's new emphasis on integration, particularly if the language requirements are strictly applied. ${ }^{380}$

There were good reasons to anticipate that Germany's new push for integration might encounter resistance within the affected population, even before controversy erupted in early 2006 over Baden-Württemburg's discriminatory naturalization questionnaire. ${ }^{381}$ In particular, the obligation to attend integration courses may be perceived as a burden by some, whereas the sanctions attached to failure may work a hardship in other cases.

\section{B. GETTING TOUGH: DEPORTATION}

Last but not least, the new Immigration Act attaches new security limitations to the newly liberalized migration regime. Most significantly, the Residence Act has introduced the possibility of deporting a foreigner with immediate effect "on the basis of a prognosis based on facts, in order to avert a special danger to the security of the Federal Republic of Germany or a terrorist threat." 382 Such a deportation order can be issued either by the competent Länder authorities or, in special cases, by the Federal Government. Only a single avenue of appeal will be available, running through the Federal Administrative Court in Leipzig. In addition, Articles 54 and 55 of the Residence Act provide a broad range of bases for ordinary or discretionary expulsion of foreigners, including anyone who: belongs to an organization which supports terrorism or supports or has supported such an organization; 383 endangers the free democratic basic order or the security of the Federal Republic or participates in acts of violence or publicly incites to violence in pursuit of political objectives or threatening the use of violence, ${ }^{384}$ or belongs to the leadership of a banned organization; ${ }^{385}$ or is an "intellectual incendiary" who

378. BAMF 2004, supra note 299, at 83-84.

379. The new integration courses must be viewed in the context of earlier efforts by the Federal Government, starting in early 2003 , to provide language training. In 2003 , for example, more than 67,000 people from 172 countries participated in government-sponsored language training. BAMF 2004, supra note 299 , at 83.

380. For example, language is "perhaps the biggest problem" for some migrant communities, such as the more than two million Russian-Germans who have come to Germany since the 1980s. Ray Furlong, Ghetto Woes Afflict Russian-Germans, BBC NEws (Dec. 8, 2004), at http://news.bbc.co.uk/1/hi/world/europe/4076245.stm (last visited Nov. 29, 2005).

381. This controversy is discussed supra in text accompanying note 356.

382. Residence Act, supra note 321 , § 58a.

383. Residence Act, supra note $321, \S 54(5)$.

384. Residence Act, supra note 321, § 54(5a).

385. Residence Act, supra note $321, \S 54(7)$. 
(a) publicly, at a meeting or by disseminating literature, endorses or promotes a crime against peace, a war crime, a crime against humanity or terrorist acts of comparable importance in a manner conducive to disturbing public safety and order, or (b) incites hate against sections of the population or calls for violence or arbitrary measures against the same in a manner conducive to disturbing public safety and order or attacks the human dignity of others by insulting, maliciously disparaging or slandering sections of the population. 386

Pursuant to the new national security provisions in the Residence Act, German officials commenced 'Operation Cleanup' (Kehraus), which involves compiling a 'black list' of Islamic extremists for deportation. ${ }^{387}$ After the new Immigration Act entered into force, numerous sources reported plans to deport hundreds of people from Germany in the near future. ${ }^{388}$ The first Muslim cleric facing deportation under the new Immigration Act is the Berlin-based cleric, Imam Yakup Tasci, who has lived in Germany since 1971 and become infamous as a preacher of hate and intolerance. ${ }^{389}$ His deportation would continue a trend that started with the deportation of Metin Kaplan-the self-styled "Caliph of Cologne"-in mid-October 2004. 390 While not alone, Germany is, among EU countries, the one making greatest use of "deportations via immigration reform."391

In the end, Germany's renewed (if not entirely new) emphasis on integration and efforts to deport undesirable aliens have the potential to

386. Residence Act, supra note $321, \S 55(2)(8)$.

387. 'Operation Kehraus': Innenminister bereiten Ausweisung Hunderter Islamisten vor ['Operation Clean Up': Interior Ministers Prepare to Deport Hundreds of Islamic Extremists], SPIEGEL ONLINE (Jan. 22, 2005), available at http://www.spiegel.de/politik/deutschland (last visited Nov. 21, 2005). See generally Liz Fekete, "Speech crime" and deportation, European Civil Liberties Network (2005), at 1, 3, available at http://www.ecln.org (last visited Nov. 21, 2005) (analyzing the increasing tendency in some EU countries, including Germany, to extend the definition of terrorism to include "speech crimes" in connection with fast-track national security deportations).

388. Id.; see also Ahmed Al-Matboli, Anti-Imam Drive Goes Unabated in Germany, ISLAMONLINE.NET (March 23, 2005), available at http://www.islamonline.net/English/News/200503/23/article05.shtml (last visited Nov. 21, 2005) (reporting the preparation of "lists of thousands of Muslim immigrants-whom the German authorities dubbed as suspects-for immediate deportation").

389. Imam Jakup T. came under increasing scrutiny in 2004 after he publicly expressed sympathy for suicide attackers in the summer and was filmed making inflammatory remarks while preaching in November 2004. The Berlin Interior Minister issued the deportation order in December 2004. Berliner Hassprediger muss Deutschland verlassen! [Berlin Hate Preacher Must Leave Germany!], NET-TRIBUNE.DE (Dec. 17, 2004), available at http://www.nettribune.de/article/171704-09.php (last visited Nov. 21, 2005). However, the German Federal Constitutional Court blocked his deportation in June 2005. Karlsruher Gericht: Kreuzberger Imam darf vorerst nicht ausgewiesen werden [Karlsruhe Court: Kreuzberg Imam May Not Yet Be Deported], DiE WELT (June 23, 2005), available at http://www.welt.de/data/1005/06/23/735922.html (last visited Nov. 21, 2005).

390. Deutschland: Kaplan in die Türkei abgeschoben [Germany: Kaplan Deported to Turkey], 8 MIGRATION UND BEVÓLKERUNG 1, 12 (Nov. 2004). Kaplan's deportation was upheld by two competent courts, the Oberverwaltungsgericht Nordrhein-Westfalen (Supreme Administrative Court for North Rhine-Westphalia), case 17 B 2251/04, and the Leipzig-based Bundesverwaltungsgericht (Federal Administrative Court), BVerwG I C 14/04, Judgment of December 7, 2004

391. Fekete, supra note 387 , at 3. 
exacerbate ethno-cultural tensions, and even to provoke a response by some sectors of Germany's immigrant population. The German legal reforms invite a series of long-term empirical inquiries about how they are implemented by German authorities, how they affect the immigrant populations, and whether they foster social peace or provoke polarization and conflict. These reforms equally compel further reflection on the relationship between the experience and practice of belonging, on the one hand, and the legal framework in which they are embedded, on the other.

\section{$\mathrm{V}$. \\ CONCLUSION}

Recent German reforms of citizenship and immigration laws radically alter the opportunities for many non-Germans who already live or wish to live in Germany, though experts continue to debate whether they provide conclusive evidence of a paradigm shift. Whatever their actual impact may be in the long run, it would go too far to assert that German legal reforms have resolved fundamental tensions over political, socio-economic or cultural inclusion. If anything, the recent legal and institutional reforms have channeled divisive social questions onto the front burner of public debate and created conditions that might well produce occasions for confrontation in the short term. Meanwhile, outbreaks of violence in the Netherlands and France have created a climate of heightened tension that is exacerbated by-though not necessarily causally linked to - developments on the political far right. ${ }^{392}$

Debates over multiculturalism are back in the headlines, as a result of increasingly visible events, blundering politicians, and vocal minorities. Tens of thousands of people, mostly Turkish men, demonstrated peacefully in Cologne in November 2004, where they protested against terrorism and pressed their claims for acceptance as members of German, as well as European society. ${ }^{393}$ The Cologne demonstration, which denounced violence and voiced the participants' commitment to social harmony and human rights, provides one but by no means the only conceivable model for migrant politics in Germany. While many members of the non-German population living in Germany have welcomed the opportunity to learn German (largely at government expense), not all have enthusiastically embraced the new official insistence on greater

392. For an analysis of mobilization against immigrants by moderate, nonviolent Germans operating at the sub-national level, see Roger Karapin, Protest and Reform in Asylum Policy: Citizen Initiatives versus Asylum Seekers in German Municipalities, 1989-1994, 21 GERMAN POL. \& SOC'Y 1 (2003). Karapin's goal is to supplement but not displace analyses linking anti-immigration politics to the radical right or to other causes. Id. at 45 . For examples of such scholarship, see HANS-GEORG

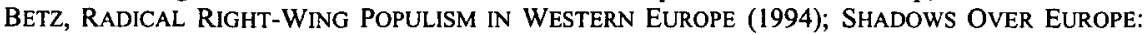
THE DEVELOPMENT AND IMPACT OF THE EXTREME RIGHT IN WESTERN EUROPE (Martin Schain, Aristide Zolberg \& Patrick Hossay eds., 2002).

393. Peter Schilder, Islam heißt Frieden [Islam Means Peace], FrankfuRTER AllgemEINE ZEITUNG, Nov. 22, 2004, at 3 (reporting a peaceful demonstration of approximately 30,000 persons). 
integration into German society. At the very least, there appear to be different opinions among migrant groups about the desirability of integration and the best way to ensure social peace.

Neither of the traditional metaphors-melting pot or boiling kettle-aptly captures changing conditions in Germany's de facto multicultural society. While I do not wish to exaggerate the level of current tensions, I believe that a frying pan metaphor is more appropriate. Radical legal reform is too often viewed as the end of a long process of debate and struggle. In my view, however, German legal reforms mark the beginning of a new phase of increasingly contentious politics, during which the new rules are implemented and their impact on existing societal relations is felt. In this sense, immigration and citizenship in Germany have moved 'out of the frying pan, but into the fire' of civil society. My initial choice of the term 'fire' was intended to invoke the notion of combustion and suggest the likely intensification of public debate and political confrontation, rather than to predict conflagration and violence. Regrettably, European developments in 2004, 2005 and 2006 have confirmed even the literal meaning of this metaphor, although Germany remains thus far virtually unaffected by the eruption of migrant rage that has badly shaken the Netherlands, France, Denmark, and other neighboring countries.

The efforts by the EU and its Member States, including Germany, to enhance both internal and external dimensions of belonging by means of legal reforms, including measures aimed at promoting integration of immigrant populations, stand in stark contrast to the enormity of the socio-economic problems on the ground. The outbreak of violence in Europe in late 2005 vividly illustrates the limitations of exclusively cultural or identity-based approaches to the question of belonging. While essential to human well-being, identity and culture provide no real substitute for education, adequate housing, or jobs. It would be a mistake to view the rioting that started in France merely as an expression of "the wrath of a Muslim community." 394 Rather, the violence that erupted in France in October 2005 and spread to other EU countries should be seen as the "temporary rising up of one small part of a Western underclass culture that reaches from Paris to London to Los Angeles and beyond" to "express simmering anger fueled by unemployment and racism." 395 Similarly, while EU-prescribed anti-discrimination laws are likely to provide a growing avenue for underprivileged persons to seek legal remedies, they cannot fully resolve the inequalities, and may even serve to exacerbate social tensions by fueling resentment against migrant groups. Such risks aside, it is far better to address the manifold challenges of belonging from all available angles, than to insist blindly on any form of monoculture-be it the CSU's vision of 'Christian-occidental culture' or French Republicanism-in the face of

394. Olivier Roy, Get French or Die Trying, New YORK TIMES, Nov. 9, 2005, at A27 ("[T]here is nothing particularly Muslim, or even French, about the violence.").

395. Id. 
real existing multiculturalism and socio-economic inequality in Europe.

Special considerations warrant further attention to the position of the EU's Turkish population, which is the largest foreign group in Germany but present in other EU Member States as well. This population's situation is complicated by the ongoing discussions over Turkey's desire to join the EU. Despite heated debates over this historical decision throughout the EU, this overarching question of belonging generated little uproar among the local Turkish population. Rather, the largest public demonstrations supporting Turkish accession to the EU took place in Turkey itself. Investigation of this phenomenon could provide valuable insight into notions of belonging among this population and attitudes towards formal legal guarantees, as well as into the dynamics of diasporic politics.

In the end, this survey of the contemporary German and EU legal landscapes affecting citizenship and migration suggests that we must greet claims that we live in a postnational world with skepticism. ${ }^{396}$ Dramatic changes in the legal framework affecting migrants in Europe in general, and Germany in particular, have loosened the grip of narrow notions of belonging in small but significant ways. Still, the ability to opt into Germany, and by extension the EU, remains elusive, even for the highly qualified and low-risk applicants who are favored by recent legislative reforms. ${ }^{397}$

The limiting notion of the territorial state remains the crux of legal belonging, despite the fact that the everyday realities of "diasporic lives" 398 lead many people to "live between different spaces." 399 I join the many who reject "the assimilationist demand to centre experience and loyalties in a single space," 400 and adopt instead a posture in which "both the nation and migration form a loci of sentiments and emotions crucial to a sense of home.,"401

396. See, e.g., WESTWOOD \& PHIZACKLEA, supra note 15, at 7 (urging those "who have suggested we are not in the era of postnationalism . . . to re-examine the ways in which they have arrived at this conclusion," which is premised on the false binary "idea that either there are nations or there is globalisation which ruptures the national project"). Rather, "nations are constituted in multi-centric ways which means that they are not unitary and that they hold within them a vast array of both centring and decentring mechanisms." Id.

397. Decision of the Stadt Köln Amt für öffentliche Ordnung-Arbeitsmigration (Aug. 15, 2005) (denying permanent settlement to an applicant who fulfilled all formal legal requirements).

398. WESTWOOD \& PHIZACKLEA, supra note 15 , at 4.

399. SEIDLER, supra note 15 , at xi.

400. Id.

401. WESTWOOD \& PHIZACKLEA, supra note 15, at 11 (emphasis added). 